\title{
Discovery of Novel Quinoline-Chalcone Derivatives as Potent Anti-tumor Agents with Microtubule Polymerization Inhibitory Activity
}

Wenlong Li, ${ }^{\dagger}$ Feijie Xu, ${ }^{\dagger}$ Wen Shuai, ${ }^{\dagger}$ Honghao Sun,$^{\dagger}$ Hong Yao, ${ }^{\dagger}$ Cong Ma, ${ }^{\star}$ Shengtao Xu, ${ }^{*}{ }^{\dagger}$ Hequan Yao, ${ }^{\dagger}$ Zheying Zhu, ${ }^{\#}$ Dong-Hua Yang, ${ }^{\S}$ Zhe-Sheng Chen, ${ }^{\S}$ Jinyi Xu ${ }^{*, \dagger}$

${ }^{\dagger}$ State Key Laboratory of Natural Medicines and Department of Medicinal Chemistry, China Pharmaceutical University, 24 Tong Jia Xiang, Nanjing 210009, P. R. China

tState Key Laboratory of Chemical Biology and Drug Discovery, and Department of Applied Biology and Chemical Technology, The Hong Kong Polytechnic University, Kowloon, Hong Kong

\#Division of Molecular Therapeutics \& Formulation, School of Pharmacy, The University of Nottingham, University Park Campus, Nottingham NG7 2RD, U. K.

${ }^{\S}$ College of Pharmacy and Health Sciences, St. John’s University, 8000 Utopia Parkway, Queens, New York 11439, United States

\section{ABSTRACT}

A series of novel quinoline-chalcone derivatives were designed, synthesized and evaluated for their antiproliferative activity. Among them, compound 24d exhibited the most potent activity with $\mathrm{IC}_{50}$ values ranging from 0.009 to $0.016 \mu \mathrm{M}$ in a panel of cancer cell lines. Compound $\mathbf{2 4 d}$ also displayed a good safety profile with $\mathrm{LD}_{50}$ value of $665.62 \mathrm{mg} / \mathrm{kg}$ by intravenous injection, and its hydrochloride salt $\mathbf{2 4 d - H C l}$ 
significantly inhibited tumor growth in H22 xenograft models without observable toxic effects, which was more potent than that of CA-4. Mechanism studies demonstrated that $\mathbf{2 4 d}$ bound to the colchicine site of tubulin, arrested cell cycle at the G2/M phase, induced apoptosis, depolarized mitochondria and induced reactive oxidative stress (ROS) generation in K562 cells. Moreover, 24d has potent in vitro anti-metastasis, in vitro and in vivo anti-vascular activities. Collectively, our findings suggest that $\mathbf{2 4 d}$ deserves to be further investigated as a potent and safe anti-tumor agent for cancer therapy.

\section{INTRODUCTION}

Microtubules provides a dynamic scaffold for maintenance of cell structure, protein trafficking, chromosomal segregation, and mitosis. ${ }^{1}$ They are long, hollow structures that are mainly composed of $\alpha$ - and $\beta$-tubulin dimers. ${ }^{2-4}$ Microtubule-targeting agents (MTAs) including microtubule stabilizers or destabilizers can interfere with microtubule dynamics, leading to mitotic blockade and cell apoptosis. ${ }^{5}$ In recent decades, MTAs that bind to the colchicine site have been attracting the interest of medicinal chemists because of their advantages over other site binders; these MTAs have simpler structures, improved aqueous solubility, broad therapeutic index, and reduced multidrug resistance (MDR) effects as comparing with other site binders. ${ }^{6-12}$ Notably, colchicine binding site inhibitors (CBSIs) can induce morphological changes in endothelial cells, thus provoking a rapid disrupt of existing tumor vasculature, and thus are commonly designated as vascular disrupting agents (VDAs). ${ }^{13,14}$

Chalcones that bear an $\alpha, \beta$-unsaturated ketone moiety represents a key structural 
motif in the plethora of biologically active molecules including synthetic and natural products. They have shown a broad range of biological activities such as antioxidant, antibacterial, antifungal, anti-HIV, anti-leishmanial, antimalarial, anti-inflammatory, and anticancer properties. ${ }^{15}$ In the development process of CBSIs, the $\alpha, \beta$-unsaturated ketone moiety of chalcones was recognized as a privileged structure. ${ }^{16-20}$ Representative anti-tubulin chalcones, presented as compounds $\mathbf{1}$ and $\mathbf{2}$ (Figure 1a), showed remarkable antiproliferative activities. ${ }^{21}$ The more preferential $s$-trans conformation adopted by $\mathbf{2}$, which could interact with tubulin more easily, led to more potent cytotoxicity than $\mathbf{1}$. Another chalcone compound reported by Li's group was compound 3, which exhibited excellent antipoliferative activity with $\mathrm{IC}_{50}$ values ranging from 3 to $9 \mathrm{nM}$ against a panel of cancer cell lines. ${ }^{22}$ Our previous work on the modification of compound $\mathbf{1}$ also led to a novel chalcone analog $\mathbf{4}$, which displayed both potent anti-vascular and anti-tumor activities. ${ }^{23}$

Nitrogenous molecules, such as pyridines and quinolines, have numerous advantages over other non-nitrogenous molecules. The introduction of nitrogen atom greatly improves the basicity of molecules due to its basic characteristic, and nitrogen atom may form a strong hydrogen bond with the targets. Another important property is the polarity which can be used as a mean of reducing the lipophilic character, improving water solubility and oral absorption. ${ }^{24}$ The quinoline motif is frequently found in natural alkaloids that exhibit a wide range of biological activities. The quinoline ring system-containing drugs, such as quinine, chloroquine, mefloquine and amodiaquine, are used as efficient treatments of malaria. ${ }^{25}$ Quinoline analogs also 
exhibit anticancer activities with different mechanisms, including alkylating agents, tyrosine kinase inhibitors and tubulin inhibitors. ${ }^{26}$

Considering the poor aqueous solubility that impeded the clinical development of some CBSIs ${ }^{27}$ incorporation of nitrogenous heterocycles, which could be salified with acids, may improve water solubility. Some examples of tubulin inhibitors bearing a quinoline skeleton are listed in Figure $1 \mathrm{~b}$, such as compounds $\mathbf{5}^{28}, \mathbf{6}^{29}$ and $\mathbf{7}$ - 11 ${ }^{30-34}$. Recently, the work performed by Alami et al. also proved that a quinoline ring as shown in compound $\mathbf{1 2}$ can replace the 3,4,5-trimethoxyphenyl moiety and provide compounds with more potent activities. ${ }^{35}$ Their docking studies predicted that the $N-1$ atom of quinoline formed a hydrogen bond with the critical residue Cys 241, which was further supported by the later disclosed crystal structure of tubulin in complex with $11 .{ }^{34}$ Thus, the quinoline moiety might be a surrogate of the 3,4,5-trimethoxyphenyl moiety when binding to the colchicine site.

Our group has concentrated on discovering and developing novel anticancer agents targeting the tubulin-microtubule system. ${ }^{23,} 36,37$ In our continuing works on the structural modification of the parent compound $\mathbf{1}$ around the 3,4,5-trimethoxyphenyl, which led to the discovery of a series of novel quinoline-chalcone derivatives (Figure 2). Meanwhile, given previous studies showed that the indole moiety was an alternative structure of the isovanillic ring. ${ }^{38,39}$ Thus, new quinoline-chalcones that contain an indole moiety were also designed and synthesized. Herein, we would like to report their synthesis and anti-tumor activities in vitro and in vivo. In addition, the underlying cytotoxic mechanisms of the representative compound $\mathbf{2 4 d}$ are also 
elucidated.

a)

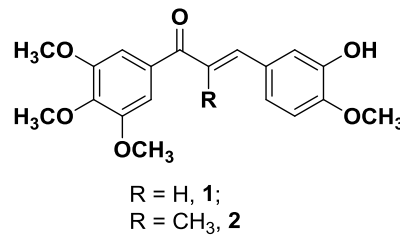

b)<smiles>COc1cc(/C=C\c2ccc3ncccc3c2)cc(OC)c1OC</smiles><smiles>COc1ccc2c(/C=C(\C)C(=O)c3cc(OC)c(OC)c(OC)c3)c[nH]c2c1</smiles>

3

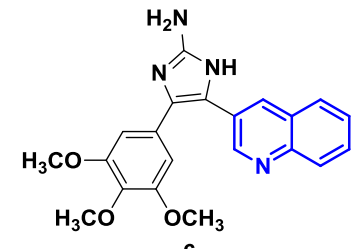

6<smiles>COc1ccc(/C=C/S(=O)(=O)c2cc(OC)c(OC)c(OC)c2)cc1O</smiles>

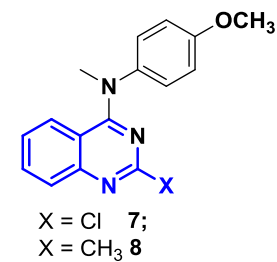<smiles>COc1ccc2c(c1)CCCN2c1nc(C)nc2ccccc12</smiles>

9<smiles>COc1ccc2c(c1)N(C)C(=O)CN2c1nc(C)nc2ccccc12</smiles>

10<smiles>COc1ccc2c(c1)CCCN2c1nc(C)nc2ncccc12</smiles>

11

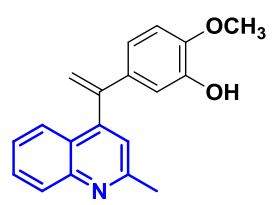

12

Figure 1. a) Representative anti-tubulin chalcones or chalcone analogs; b) Tubulin inhibitors bearing quinoline and quinazoline skeletons.
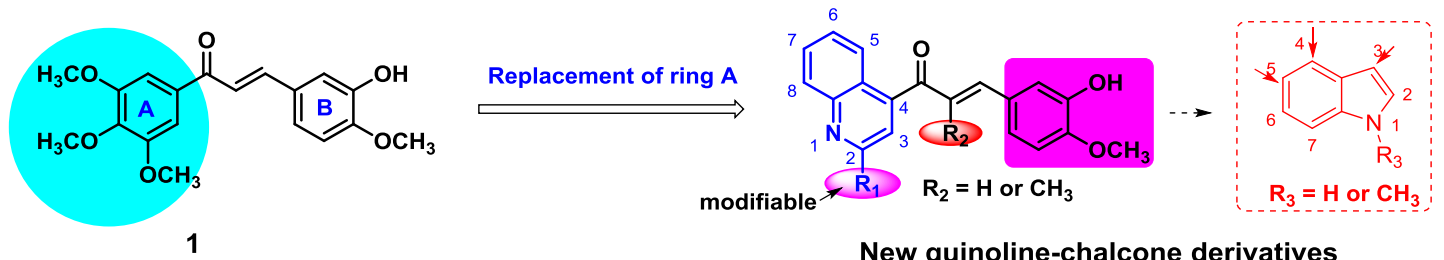

New quinoline-chalcone derivatives

Figure 2. Design strategy of novel quinoline-chalcone derivatives.

\section{RESULTS AND DISCUSSION}

Chemical Synthesis. In Alami's previous work, ${ }^{35}$ the effects of different substitutions at the $\mathrm{C}-2$ position of quinoline were investigated in detail with a methyl group being the most active. Thus, 2-methylquinoline was first chosen to replace the 3,4,5-trimethoxyphenyl moiety of compound 1 . The synthetic route of key 
intermediates acetylquinoline $\mathbf{1 6}$ and propionylquinoline $\mathbf{2 1}$ was outlined in Scheme 1. 2-Methylquinoline-4-carboxylic acid (14) was prepared by refluxing the commercially available material isatin (13) with acetone under basic conditions, which was further converted into Weinreb amide 15, and $\mathbf{1 5}$ reacted with methylmagnesium bromide $\left(\mathrm{CH}_{3} \mathrm{MgBr}\right)$ to obtain acetylquinoline $\mathbf{1 6}$ in high yields. Disappointingly, this method was not applicable for the synthesis of propionylquinoline $\mathbf{2 1}$ due to the overreaction of $\mathbf{2 1}$ with ethylmagnesium bromide $\left(\mathrm{C}_{2} \mathrm{H}_{5} \mathrm{MgBr}\right)$ resulting in a great decreased yield. Thus, we attempted a tedious but effective route to synthesize 21. 2-Methylquinoline-4-carbaldehyde (19) was prepared by the oxidation of $\mathbf{1 8}$ according to the previous report ${ }^{[40]}$. Then, $\mathbf{1 9}$ underwent nucleophilic attack by $\mathrm{CH}_{3} \mathrm{CH}_{2} \mathrm{MgBr}$ to obtain $\mathbf{2 0}$, which was subsequently oxidized to produce the propionylquinoline 21 .

The designed target compounds $\mathbf{2 4 a - o}$ containing a 2-methylquinoline moiety were synthesized using acetylquinoline $\mathbf{1 6}$ or propionylquinoline $\mathbf{2 1}$ with various commercially available aldehydes via aldol condensation reactions (Scheme 2). Compound 24a and 24b bearing amino groups were synthesized using 3-nitro-4-methoxybenzaldehyde (22) in the condensation steps, after which the nitro group was reduced to amino group to afford $\mathbf{2 4 a}$ and $\mathbf{2 4 b}$. Similarly, the MEM protective group was used to synthesize $\mathbf{2 4} \mathbf{c}$ and $\mathbf{2 4 d}$ bearing an isovanillic ring. The aldol reactions of $\mathbf{1 6}$ or $\mathbf{2 1}$ with various benzaldehydes or indole formaldehydes

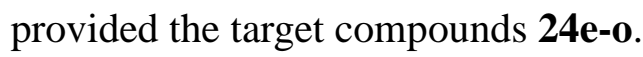


Scheme 1. The synthetic route of key intermediates $\mathbf{1 6}$ and $\mathbf{2 1}^{a}$.

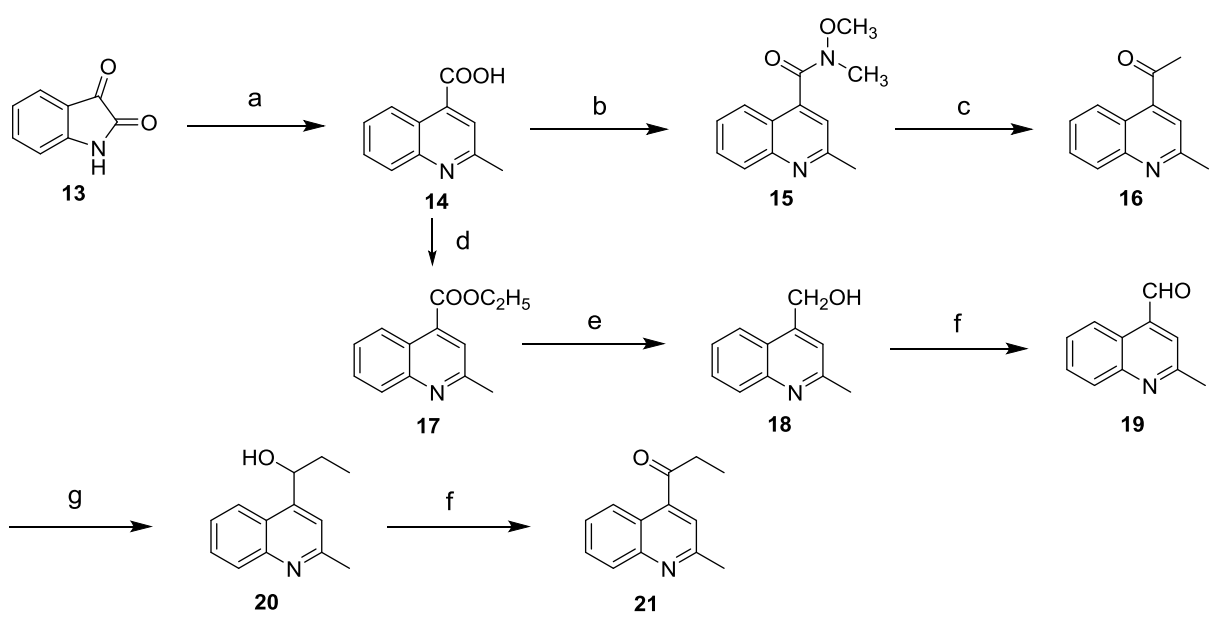

${ }^{a}$ Reagents and conditions: (a) $85 \% \mathrm{KOH}$ aqueous, acetone, $50{ }^{\circ} \mathrm{C}, 24 \mathrm{~h}, 82.3 \%$; (b) $\mathrm{CH}_{3} \mathrm{NHOCH}_{3}-\mathrm{HCl}$, EDCI, HOBt, DMAP(cat.), DCM, rt, $2 \mathrm{~h}, 83.1 \%$; (c) $\mathrm{CH}_{3} \mathrm{MgBr}$, THF, $0{ }^{\circ} \mathrm{C}$ to rt, 2 h, 84.0\%; (d) i) oxalyl chloride, DMF (cat.), DCM; ii) $\mathrm{C}_{2} \mathrm{H}_{5} \mathrm{OH} ; 72.2 \%$ over two steps; (e) $\mathrm{NaBH}_{4}, \mathrm{CH}_{3} \mathrm{OH} ; 0{ }^{\circ} \mathrm{C}$ to rt, 4 h, 63.5\%; (f) Dess-Martin reagent, DCM; 2 h, rt, 65.1-80.0\%; (g) $\mathrm{C}_{2} \mathrm{H}_{5} \mathrm{MgBr}$, THF, $0{ }^{\circ} \mathrm{C}$ to rt, $2 \mathrm{~h}, 74.1 \%$.

Subsequently, compounds bearing a quinoline moiety with varying substitutions at the C-2 position were designed and synthesized. Compounds 29a and 29b with hydroxymethyl and formyl groups at the C-2 position of the quinoline ring were synthesized as shown in Scheme 3. Intermediate $\mathbf{2 8}$ was prepared by a rearrangement reaction of quinoline- $N$-oxide 27, and a further aldol reaction with MEM protected isovanillin $\mathbf{2 5}$ led to $\mathbf{2 9 a}$, which was oxidized to formyl substituted target compound $29 b$.

Scheme 2. The synthetic route of key intermediates $\mathbf{2 4 a - \mathbf { o } ^ { a }}$. 

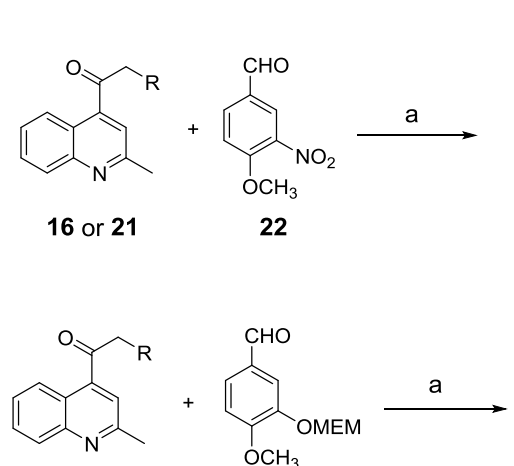

16 or 21

22

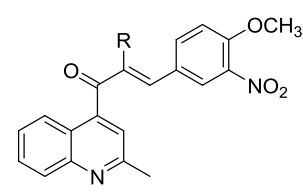

23a: $\mathrm{R}=\mathrm{H}$; 23b: $\mathrm{R}=\mathrm{CH}_{3}$
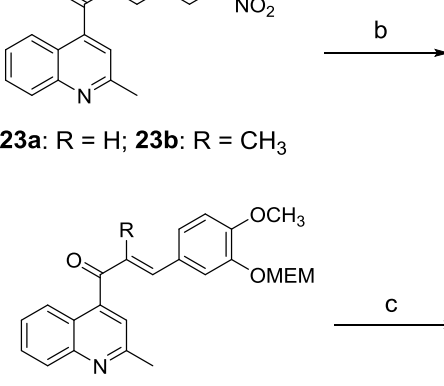

26a: $\mathrm{R}=\mathrm{H} ; \mathbf{2 6 b}: \mathrm{R}=\mathrm{CH}_{3}$

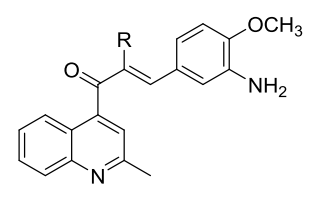

24a: $\mathrm{R}=\mathrm{H} ; \mathbf{2 4 b}: \mathrm{R}=\mathrm{CH}_{3}$

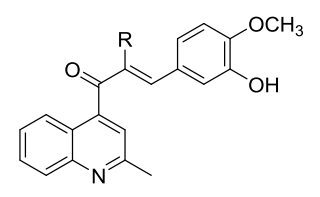

24c: $R=H$; 24d: $R=\mathrm{CH}_{3}$

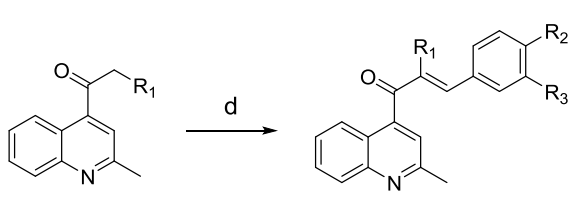

16 or $2124 e: R_{1}=C_{3}, R_{2}=O_{3}, R_{3}=H$; 24f: $\mathrm{R}_{1}=\mathrm{CH}_{3}, \mathrm{R}_{2}=\mathrm{OCH}_{3}, \mathrm{R}_{3}=\mathrm{OCH}_{3}$ 24g: $R_{1}=\mathrm{CH}_{3}, \mathrm{R}_{2}=\mathrm{OCH}_{3}, \mathrm{R}_{3}=\mathrm{F}$; 24h: $R_{1}=\mathrm{CH}_{3}, \mathrm{R}_{2}=\mathrm{SCH}_{3}, \mathrm{R}_{3}=\mathrm{H}$;

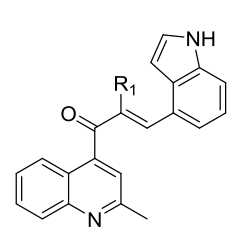

24i: $\mathrm{R}=\mathrm{H}$;

24I: $\mathrm{R}_{1}=\mathrm{CH}_{3}, \mathrm{R}_{2}=\mathrm{H}$;

24m: $\mathrm{R}_{1}, \mathrm{R}_{2}=\mathrm{CH}_{3}$
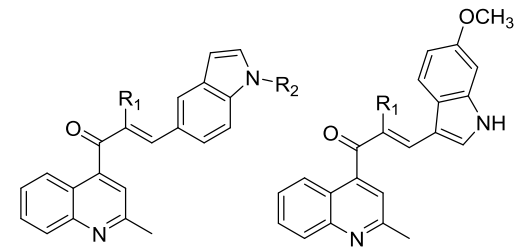

24n: $\mathrm{R}=\mathrm{H}$;

240: $\mathrm{R}=\mathrm{CH}_{3}$

${ }^{a}$ Reagents and conditions: (a) $\mathrm{NaOH}$, EtOH, rt, 30 min, moderate yields; (b) $\mathrm{Fe}, \mathrm{AcOH}, \mathrm{EtOH}$, reflux; 62.5-73.2\%; (c) $10 \% \mathrm{HCl}$, EtOH, 30 min, 85-95\%; (d) different benzaldehydes, $\mathrm{NaOH}$, $\mathrm{EtOH}, \mathrm{rt}, 30 \mathrm{~min}$, moderate yields or different indole formaldehydes, piperidine, EtOH, reflux, moderate yields.

Scheme 3. The synthetic route of key intermediates $29 \mathbf{a}$ and $29 \mathbf{b}^{a}$.<smiles>CCC(=O)c1cc(C)nc2ccccc12</smiles>

21

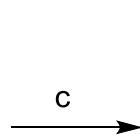<smiles>CCC(=O)c1cc(C)nc2ccccc12</smiles>

$27 \mathrm{O}$

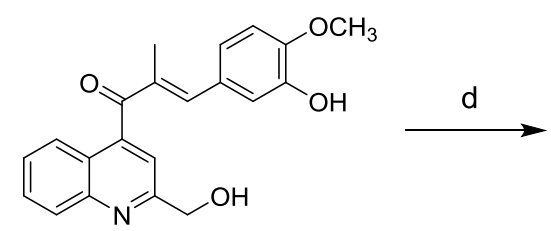

29a

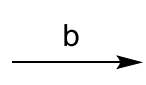<smiles>CCC(=O)c1cc(CO)nc2ccccc12</smiles>

28<smiles>COc1ccc(C=O)cc1OC</smiles>

25<smiles>COc1ccc(/C=C(\C)C(=O)c2cc(C=O)nc3ccccc23)cc1O</smiles>

29b

${ }^{a}$ Reagents and conditions: (a) $m$-CPBA, DCM, 2 h, rt, 89.0\%; (b) i) $\mathrm{Ac}_{2} \mathrm{O}$, reflux, $2 \mathrm{~h}, 86.2 \%$; ii)

$10 \% \mathrm{NaOH}$ aqueous, $\mathrm{CH}_{3} \mathrm{OH}, 30 \mathrm{~min}, 88.2 \%$; (c) i) $\mathrm{NaOH}, \mathrm{EtOH}$, rt, $30 \mathrm{~min}$; ii) $10 \% \mathrm{HCl}, \mathrm{EtOH}$, reflux, $30 \mathrm{~min}$; 43.7\%; (d) IBX, DMSO, rt, $30 \mathrm{~min}, 74.9 \%$. 
Chloro-substituted propionylquinoline 36 was prepared as shown in Scheme 4. Intermediate $\mathbf{3 0}$ was prepared by refluxing isatin $\mathbf{1 3}$ with malonic acid in glacial acetic acid, following a chlorination by $\mathrm{POCl}_{3}$ leading to 2-chloroquinoline-4carboxylic acid (31), which was converted to propionylquinoline $\mathbf{3 6}$ according to the synthesis method of intermediate 21. Propionylquinolines 37a-c were prepared by nucleophilic reactions of $\mathbf{3 6}$ with secondary amines. Because primary amines can react with the ketone group of $\mathbf{3 6}$ to form Schiff bases, we used 35, the precursor of 36, to react with various primary amines followed by oxidations by IBX to afford intermediates 39a-d. Cyano containing propionylquinoline 40 was prepared by a Pd-catalyzed coupling reaction of $\mathbf{3 6}$ with $\mathrm{Zn}(\mathrm{CN})_{2}$, and a methoxy group was introduced by a nucleophilic reaction of 36 with $\mathrm{NaOCH}_{3}$ to give intermediate 41 . In our attempts to introduce a mesyl group to the C-2 position of quinoline, the lactam 42 was occasionally obtained, which was then used for the next derivation to synthesize compound 29m. Propionylquinoline 45 was prepared using commercially available quinolone-4-carbaldehyde (43) as the starting material.

Scheme 4. The synthetic route of key intermediates ${ }^{a}$. 


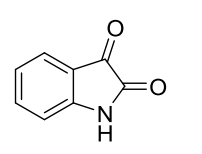

13

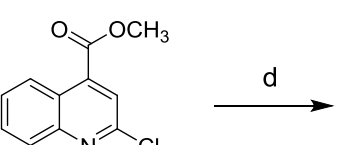

32<smiles>CCCCOCCCC</smiles><smiles>Cc1cc(Cl)nc2ccccc12</smiles>

35

$\downarrow h$

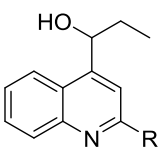

38a-d<smiles>CCC(=O)c1cc(C#N)nc2ccccc12</smiles>

40
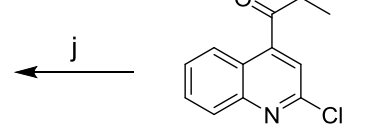

36

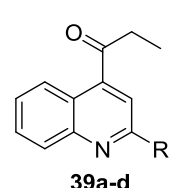

36
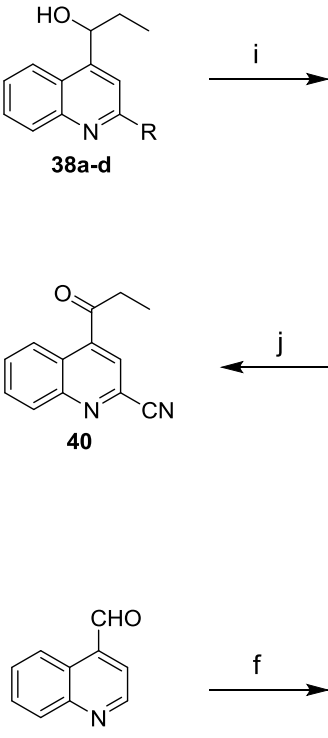

43

30<smiles>OCc1cc(Cl)nc2ccccc12</smiles>

33

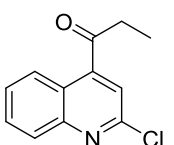<smiles>O=C(O)c1cc(=O)[nH]c2ccccc12</smiles>
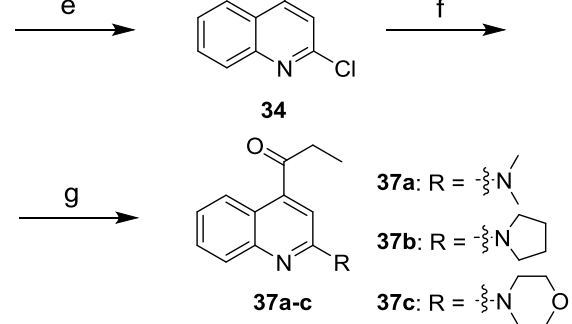

39a: $\mathrm{R}=\mathrm{NHCH}_{3}$

39b: $\mathrm{R}=\mathrm{NHC}_{2} \mathrm{H}_{5}$

39c: $\mathrm{R}=\xi_{2} \cdot \mathrm{N}^{\mathrm{H}}$

39d: $\mathrm{R}={ }_{2}$
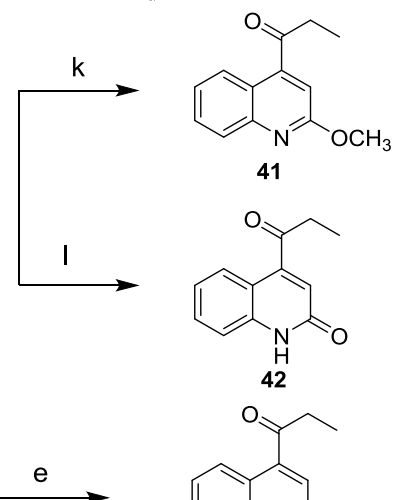

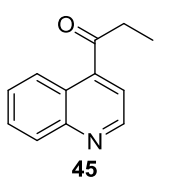

${ }^{a}$ Reagents and conditions: (a) malonic acid, $\mathrm{AcOH}$, reflux, overnight, 85.6\%; (b) $\mathrm{POCl}_{3}$, reflux, 2 h, 72.3\%; (c) i) oxalyl chloride, DMF (cat.), DCM, $0{ }^{\circ} \mathrm{C}$ - rt, 1 h; ii) $\mathrm{C}_{2} \mathrm{H}_{5} \mathrm{OH}, \mathrm{rt}, 30 \mathrm{~min}, 72.0 \%$ over two steps; (d) $\mathrm{NaBH}_{4}, \mathrm{CH}_{3} \mathrm{OH}, 0{ }^{\circ} \mathrm{C}$ - rt, $2 \mathrm{~h}, 83.8 \%$; (e) Dess-Martin reagent, DCM, 30 min, rt, moderate to high yields; (f) $\mathrm{C}_{2} \mathrm{H}_{5} \mathrm{MgBr}$, THF, $0{ }^{\circ} \mathrm{C}-\mathrm{rt}, 2 \mathrm{~h}, 72.9 \%$; (g) various secondary amines, EtOH, $80{ }^{\circ} \mathrm{C}$, sealed tube, $81-88 \%$; (h) various primary amines, EtOH, $150{ }^{\circ} \mathrm{C}$, sealed tube, 2 d, moderate yields; (i) IBX, DMSO, 30 min, rt, 45.0-56.9\%; (j) $\mathrm{Pd}\left(\mathrm{PPh}_{3}\right)_{4}, \mathrm{Zn}(\mathrm{CN})_{2}, \mathrm{DMF}$, $120^{\circ} \mathrm{C}, 2 \mathrm{~h}, 87.0 \%$; (k) $\mathrm{NaOCH}_{3}, \mathrm{CH}_{3} \mathrm{OH}$, reflux, 4 h, 88.4\%; (l) $\mathrm{CH}_{3} \mathrm{SO}_{2} \mathrm{Na}, \mathrm{H}_{2} \mathrm{O}, \mathrm{AcOH}, 90{ }^{\circ} \mathrm{C}$, overnight, $87.3 \%$. 
The synthetic route of target compounds $29 \mathrm{c}-\mathbf{n}$ was outlined in Scheme 5. Intermediates 36, 37a-c, 39a-d, 41, 42 and 45 underwent aldol reactions with MEM protected isovanillin 25, after which MEMs were removed to obtain target compounds 29c-m. The cyano group hydrolyzed to ethyl ester led to compound $29 n$ in the aldo condensation reaction of intermediate $\mathbf{4 0}$ with $\mathbf{2 5}$.

Scheme 5. The synthetic route of target compounds $29 \mathrm{c}-\mathbf{n}^{a}$.

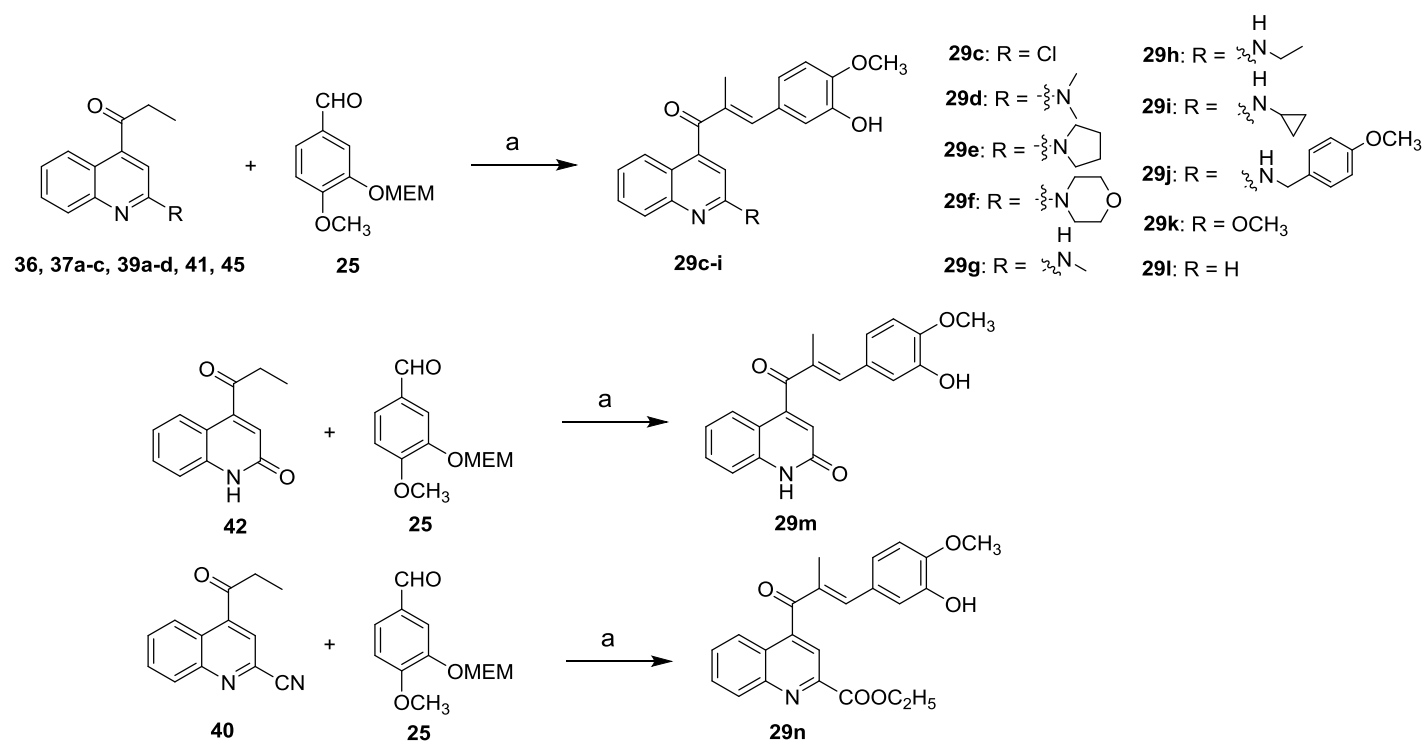

${ }^{a}$ Reagents and conditions: (a) i) $\mathrm{NaOH}, \mathrm{EtOH}, \mathrm{rt}, 30$ min, moderate yields; ii) $10 \% \mathrm{HCl}, \mathrm{EtOH}$, reflux, $30 \mathrm{~min}, 85-95 \%$.

\section{BIOLOGY}

Antiproliferative Activities and the structure activity relationships (SARs). The in vitro antiproliferative efficacy of target compounds $\mathbf{2 4 a - q}$ with a 2-methylquinoline moiety were first assessed by MTT assays using human chronic myelogenous leukemia cell K562 and compared to the reference compound CA-4. As

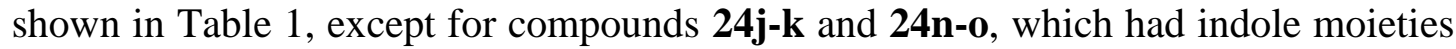


as ring $\mathrm{B}$, all of the newly synthesized compounds exhibited decent antiproliferative activities in a nanomolar range. Among which, compounds $\mathbf{2 4 b}$ and $\mathbf{2 4 d}$, featuring 3-amino-4-methoxyphenyl or 3-hydroxy-4-methoxyphenyl moieties, displayed the most potent activity with $\mathrm{IC}_{50}$ values of 0.011 and $0.009 \mu \mathrm{M}$, respectively, which were comparable to that of CA-4 $\left(\mathrm{IC}_{50}=0.011 \mu \mathrm{M}\right)$ and were approximately 6-fold more potent than the parent compound $\mathbf{1}\left(\mathrm{IC}_{50}=0.060 \mu \mathrm{M}\right)$. The methyl substituent at the $\alpha$-position of the unsaturated carbonyl group improved the activity (24a vs. $\mathbf{2 4 b}, \mathbf{2 4 c}$ vs. $\mathbf{2 4 d}$ and $\mathbf{2 4 k}$ vs. $\mathbf{2 4 l}$ ), which was similar to the results in previous reports ${ }^{[21,22]}$. Additionally, different substituted indole derivatives 24i-q were synthesized and evaluated for their antiproliferative activity. However, most of this series displayed lower activities $\left(\mathrm{IC}_{50}>1 \mu \mathrm{M}\right)$ than the phenyl counterparts, except compounds $24 \mathrm{I}$ and $\mathbf{2 4 m}$, of which the unsaturated double bonds were substituted at the C-5 position on indole moiety. Besides, the methyl substituent at the $\mathrm{N}-1$ position of the indole $(\mathbf{2 4 m})$ increased the activity for approximately 5-fold when compared to the non-substituted counterpart $\mathbf{2 4 1}$.

The effects of substitutions at the $\mathrm{C}-2$ position on the quinoline moiety on activity were further investigated with both the isovanillic ring and methyl substituted $\alpha$, $\beta$-unsaturated ketone retained. Thus, compounds 29a-n with different substituted quinolines were synthesized and evaluated for their antiproliferative efficacy. As shown in Table 1, all compounds 29a-n displayed decent activities except 29m, which had a lactam rather than the quinoline ring. Steric hindrance of the groups at the C-2 position on the quinoline moiety seemed to exert a critical influence on the activity, as 
compounds with smaller substitutions such as $\mathrm{CH}_{3}\left(\mathbf{2 4 d}, \mathrm{IC}_{50}=0.009 \mu \mathrm{M}\right), \mathrm{NHCH}_{3}$ $\left(\mathbf{2 9 g}, \mathrm{IC}_{50}=0.018 \mu \mathrm{M}\right), \mathrm{OCH}_{3}\left(\mathbf{2 9 k}, \mathrm{IC}_{50}=0.030 \mu \mathrm{M}\right)$, and $\mathrm{H}\left(\mathbf{2 9 1}, \mathrm{IC}_{50}=0.015 \mu \mathrm{M}\right)$ were more active than other compounds with larger groups. Interestingly, the $\mathrm{CH}_{3}$ substituted compound 24d exhibited a slightly more potent activity than the correspond non-substituted counterpart 291, though the methyl group has a larger steric hindrance than hydrogen.

The positive results of the antiproliferative activities of newly designed quinoline-chalcone derivatives against K562 cells led us to further evaluate the biological functions against more cancer cell lines. Four additional cancer cell lines, including human hepatocellular carcinoma (HepG2), epidermoid carcinoma of the nasopharynx (KB), human colon cancer cells (HCT-8) and human breast cancer cells (MDA-MB-231), were chosen for further evaluation. The cytotoxic data of representative compounds against these four cancer cell lines were shown in Table 2, which indicated that the $\mathrm{IC}_{50}$ values of selected compounds against these four cancer cell lines were in nanomolar ranges. The K562 cell was the most sensitive cell line among the five cancer cell lines tested, and the most active compound $\mathbf{2 4 d}$ exhibited comparable activity to the reference compound CA-4 with $\mathrm{IC}_{50}$ values ranging from 0.009 to $0.016 \mu \mathrm{M}$. Notably, 24d displayed an approximately 6-fold improvement in activity compared with the parent compound $\mathbf{1}$. The SARs of the newly synthesized compounds were summarized in Figure 3.

Table 1. Antiproliferative activities of compounds 24a-q and 29a-n against K562 cell line ${ }^{a}$.

\begin{tabular}{ll||ll}
\hline Compd. & $\mathrm{IC}_{50}$ values $(\mu \mathrm{M})^{b}$ & Compd. & $\mathrm{IC}_{50}$ values $(\mu \mathrm{M})^{b}$ \\
\hline
\end{tabular}




\begin{tabular}{|c|c|c|c|}
\hline & K562 & & K562 \\
\hline $24 a$ & $0.850 \pm 0.032$ & $29 b$ & $0.110 \pm 0.008$ \\
\hline $24 b$ & $0.011 \pm 0.001$ & $29 \mathrm{c}$ & $0.053 \pm 0.006$ \\
\hline $24 c$ & $0.127 \pm 0.07$ & 29d & $0.049 \pm 0.001$ \\
\hline 24d & $0.009 \pm 0.001$ & $29 e$ & $0.315 \pm 0.033$ \\
\hline $24 \mathrm{e}$ & $0.108 \pm 0.009$ & $29 f$ & $0.153 \pm 0.014$ \\
\hline $24 f$ & $1.055 \pm 0.040$ & $29 \mathrm{~g}$ & $0.018 \pm 0.003$ \\
\hline $24 g$ & $0.069 \pm 0.007$ & $29 h$ & $0.040 \pm 0.005$ \\
\hline $24 \mathrm{~h}$ & $0.563 \pm 0.021$ & $29 \mathrm{i}$ & $0.058 \pm 0.008$ \\
\hline $24 \mathbf{i}$ & $>1$ & 29j & $0.330 \pm 0.028$ \\
\hline $\mathbf{2 4 j}$ & $>1$ & $29 k$ & $0.026 \pm 0.004$ \\
\hline $24 k$ & $>1$ & 291 & $0.015 \pm 0.001$ \\
\hline 241 & $0.346 \pm 0.015$ & $29 m$ & $1.239 \pm 0.055$ \\
\hline $24 m$ & $0.074 \pm 0.009$ & $29 n$ & $0.120 \pm 0.015$ \\
\hline $24 n$ & $>1$ & 1 & $0.060 \pm 0.007$ \\
\hline 240 & $>1$ & CA-4 & $0.011 \pm 0.001$ \\
\hline 29a & $0.050 \pm 0.004$ & & \\
\hline
\end{tabular}

${ }^{a}$ Cells were treated with different concentrations of the compounds for $72 \mathrm{~h}$. Cell viability was measured by an MTT assay as described in the Experimental Section.

${ }^{b} \mathrm{IC}_{50}$ values are indicated as the mean $\pm \mathrm{SD}$ (standard deviation) of at least three independent experiments.

Table 2. Antiproliferative activities of representative compounds against four cancer cell lines ${ }^{a}$. 
IC $_{50}$ values $(\mu \mathrm{M})^{b}$

\begin{tabular}{|c|c|c|c|c|}
\hline & HepG2 & $\mathrm{KB}$ & HCT-8 & MDA-MB-231 \\
\hline $24 a$ & $0.223 \pm 0.021$ & $0.189 \pm 0.015$ & $0.21 \pm 0.010$ & $0.195 \pm 0.011$ \\
\hline $24 b$ & $0.036 \pm 0.008$ & $0.025 \pm 0.003$ & $0.036 \pm 0.005$ & $0.063 \pm 0.009$ \\
\hline $24 c$ & $0.121 \pm 0.010$ & $0.123 \pm 0.022$ & $0.137 \pm 0.015$ & $0.112 \pm 0.013$ \\
\hline 24d & $0.015 \pm 0.002$ & $0.016 \pm 0.001$ & $0.015 \pm 0.003$ & $0.015 \pm 0.004$ \\
\hline 241 & $0.226 \pm 0.021$ & $0.429 \pm 0.034$ & $0.421 \pm 0.035$ & $0.425 \pm 0.025$ \\
\hline $24 m$ & $0.111 \pm 0.009$ & $0.124 \pm 0.013$ & $0.135 \pm 0.011$ & $0.220 \pm 0.016$ \\
\hline 29a & $0.165 \pm 0.012$ & $0.231 \pm 0.022$ & $0.242 \pm 0.018$ & $0.209 \pm 0.015$ \\
\hline $29 \mathrm{c}$ & $0.187 \pm 0.014$ & $0.237 \pm 0.023$ & $0.227 \pm 0.026$ & $0.183 \pm 0.014$ \\
\hline 29d & $0.057 \pm 0.003$ & $0.043 \pm 0.008$ & $0.052 \pm 0.006$ & $0.048 \pm 0.005$ \\
\hline $29 \mathrm{~g}$ & $0.027 \pm 0.003$ & $0.029 \pm 0.006$ & $0.040 \pm 0.009$ & $0.043 \pm 0.007$ \\
\hline $29 k$ & $0.038 \pm 0.002$ & $0.052 \pm 0.006$ & $0.061 \pm 0.008$ & $0.052 \pm 0.008$ \\
\hline 291 & $0.024 \pm 0.001$ & $0.026 \pm 0.001$ & $0.037 \pm 0.003$ & $0.030 \pm 0.007$ \\
\hline 1 & $0.102 \pm 0.010$ & $0.108 \pm 0.005$ & $0.104 \pm 0.010$ & $0.102 \pm 0.009$ \\
\hline CA-4 & $0.012 \pm 0.001$ & $0.012 \pm 0.002$ & $0.015 \pm 0.004$ & $0.015 \pm 0.003$ \\
\hline
\end{tabular}

${ }^{a}$ Cells were treated with different concentrations of the compounds for $72 \mathrm{~h}$. Cell viability was measured by the MTT assay as described in the Experimental Section.

${ }^{b} \mathrm{IC}_{50}$ values are indicated as the mean $\pm \mathrm{SD}$ (standard deviation) of at least three independent experiments. 


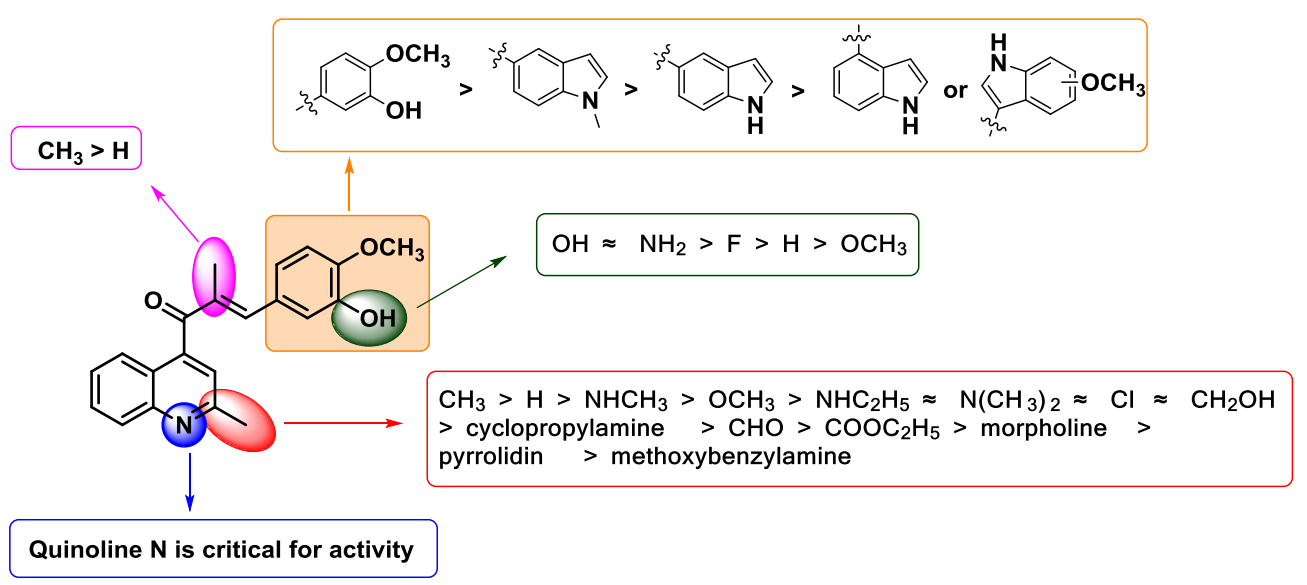

Figure 3. Summarized SARs of the new synthesized compounds.

\section{Compound 24d Selectively Inhibited Cancer Cell Growth In Vitro.}

Nonselective cytotoxicity is one of the main factors limiting the clinical use of anticancer drugs. ${ }^{41}$ To obtain insights into the cytotoxic potential of these new compounds on normal human cells, the effects of compounds $24 \mathbf{b}, \mathbf{2 4 d}, \mathbf{2 9 g}$, and $29 \mathrm{I}$ were evaluated in the normal human liver cell line L-O2 with CA-4 as the reference, which were compared with the $\mathrm{IC}_{50}$ values against human hepatocellular carcinoma cells (HepG2). As shown in Table 3, all the tested compounds showed high selectivity in inhibiting the growth of HepG2 cells vs. L-O2 cells with selective index (SI) values ( $\mathrm{IC}_{50}$ of normal cells/IC 50 of tumor cells) ranging from 24.1 to 65.8 while the SI value of the reference CA-4 was only 7.9. Importantly, the most potent compound in cancer cell antiproliferative assays, $\mathbf{2 4 d}$, was the most selective with an SI value of 65.8. Thus, 24d was chosen for further biological studies.

Table 3. Antiproliferative activities of compounds $24 \mathrm{~b}, 24 \mathrm{~d}, 29 \mathrm{~g}, 29 \mathrm{k}$ and $29 \mathrm{l}$ against normal human liver cell line L-O2 ${ }^{a}$. 


\begin{tabular}{|c|c|c|c|}
\hline \multirow{2}{*}{ Compd. } & \multicolumn{2}{|c|}{$\mathrm{IC}_{50}$ values $(\mu \mathrm{M})^{b}$} & \multirow{2}{*}{ Selective Index ${ }^{c}$} \\
\hline & HepG2 & $\mathrm{L}-\mathrm{O} 2$ & \\
\hline $24 b$ & $0.036 \pm 0.008$ & $0.923 \pm 0.056$ & 25.6 \\
\hline 24d & $0.015 \pm 0.002$ & $0.987 \pm 0.064$ & 65.8 \\
\hline $29 \mathrm{~g}$ & $0.027 \pm 0.003$ & $1.086 \pm 0.101$ & 40.2 \\
\hline $29 k$ & $0.038 \pm 0.002$ & $0.914 \pm 0.091$ & 24.1 \\
\hline 291 & $0.024 \pm 0.001$ & $0.928 \pm 0.082$ & 38.7 \\
\hline CA-4 & $0.012 \pm 0.001$ & $0.095 \pm 0.012$ & 7.9 \\
\hline
\end{tabular}

${ }^{a}$ Cells were treated with different concentrations of the compounds for $72 \mathrm{~h}$. Cell viability was measured by an MTT assay as described in the Experimental Section.

${ }^{b} \mathrm{IC}_{50}$ values are indicated as the mean $\pm \mathrm{SD}$ (standard deviation) of at least three independent experiments.

${ }^{c}$ Selectivity index $=\left(\mathrm{IC}_{50} \mathrm{~L}-\mathrm{O} 2\right) /\left(\mathrm{IC}_{50} \mathrm{HepG} 2\right)$.

\section{Compound 24d Inhibited Tubulin Polymerization and Colchicine Binding}

Effects. To investigate whether the antiproliferative activity of compound 24d was related to interactions with microtubule systems, $\mathbf{2 4 d}$ was evaluated for in vitro microtubule polymerization activity. The typical microtubule depolymerization agent (MDA) colchicine was employed as the reference. As shown in Figure 4, compound 24d displayed a concentration-dependent inhibition of tubulin polymerization, indicating that the mechanism of $\mathbf{2 4 d}$ was consistent with colchicine as an MDA. Moreover, 24d exhibited more potent tubulin polymerization inhibitory activity $\left(\mathrm{IC}_{50}\right.$ $=1.71 \mu \mathrm{M})$ than $\mathrm{CA}-4\left(\mathrm{IC}_{50}=2.53 \mu \mathrm{M}\right)($ Table 4$)$. In addition, 24d competed with 
$[3 \mathrm{H}]$-colchicine in binding to tubulin. The binding potency of $\mathbf{2 4 d}$ to the colchicine binding site was comparable to that of CA-4 with the inhibition rates of $79.4 \%$ and 92.7\% at $1 \mu \mathrm{M}$ and $5 \mu \mathrm{M}$, respectively (Table 4), indicating that $\mathbf{2 4 d}$ bound to the colchicine binding site similar to CA-4.

\section{Compound 24d Disrupted the Organization of the Cellular Microtubule}

Network in $\mathbf{K 5 6 2}$ cells. The inhibitory effects of $\mathbf{2 4 d}$ on microtubule organization were further investigated by immunofluorescent staining in K562 cells. As shown in Figure 5, the microtubule networks in vehicle-treated cells had a normal arrangement with slim and fibrous microtubules wrapped around the cell nucleus. However, after exposure to $\mathbf{2 4 d}$ at three different concentrations ( $5 \mathrm{nM}, 10 \mathrm{nM}$, and $20 \mathrm{nM})$ for $24 \mathrm{~h}$, the microtubule organization in the cytosol were disrupted especially for the group that was treated with $\mathbf{2 4 d}$ at $30 \mathrm{nM}$, indicating that $\mathbf{2 4 d}$ induced disruption of the microtubule networks, which might eventually lead to cell apoptosis.

Table 4. Inhibition of Tubulin Polymerization ${ }^{a}$ and Colchicine Binding to Tubulin ${ }^{b}$.

\begin{tabular}{|c|c|c|c|}
\hline \multirow{3}{*}{ Compd. } & \multirow{2}{*}{ Inhibition of tubulin polymerizaion } & \multicolumn{2}{|c|}{ Inhibition of colchicine binding } \\
\hline & & \multicolumn{2}{|c|}{$(\%)$ inhibition $\pm \mathrm{SD}$} \\
\hline & $\mathrm{IC}_{50}(\mu \mathrm{M})$ & $1 \mu \mathrm{M}$ & $5 \mu \mathrm{M}$ \\
\hline 24d & $1.71 \pm 0.08$ & $79.4 \pm 4.4$ & $92.7 \pm 4.7$ \\
\hline CA-4 & $2.53 \pm 0.19$ & $81.2 \pm 1.9$ & $93.7 \pm 4.4$ \\
\hline
\end{tabular}

${ }^{a}$ The tubulin assembly assay measured the extent of assembly of $2 \mathrm{mg} / \mathrm{mL}$ tubulin after $60 \mathrm{~min}$ at

$37^{\circ} \mathrm{C}$. Data are presented as the mean \pm SD from three independent experiments.

${ }^{b}$ Tubulin, $1 \mu \mathrm{M}$; $[3 \mathrm{H}]$-colchicine, $5 \mu \mathrm{M}$; and inhibitors, 1 or $5 \mu \mathrm{M}$. 


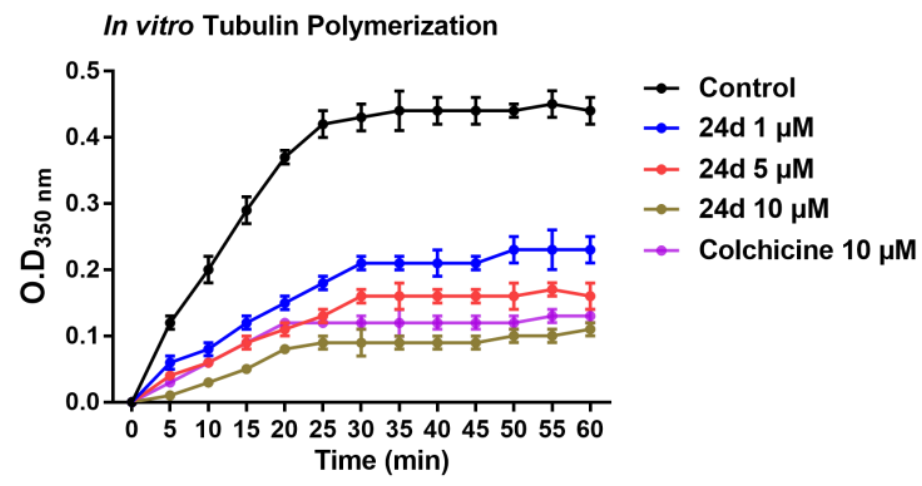

Figure 4. Effect of $\mathbf{2 4 d}$ on tubulin polymerization in vitro. Purified tubulin protein at $2 \mathrm{mg} / \mathrm{mL}$ in a reaction buffer incubated at $37{ }^{\circ} \mathrm{C}$ in the presence of $1 \%$ DMSO, test compounds $(\mathbf{2 4 d}$ at 1,5 , or $10 \mu \mathrm{M})$ or colchicine $(10 \mu \mathrm{M})$. Polymerizations were followed by an increase in fluorescence emission at $350 \mathrm{~nm}$ over a $60 \mathrm{~min}$ period at $37^{\circ} \mathrm{C}$. The experiments were performed three times.

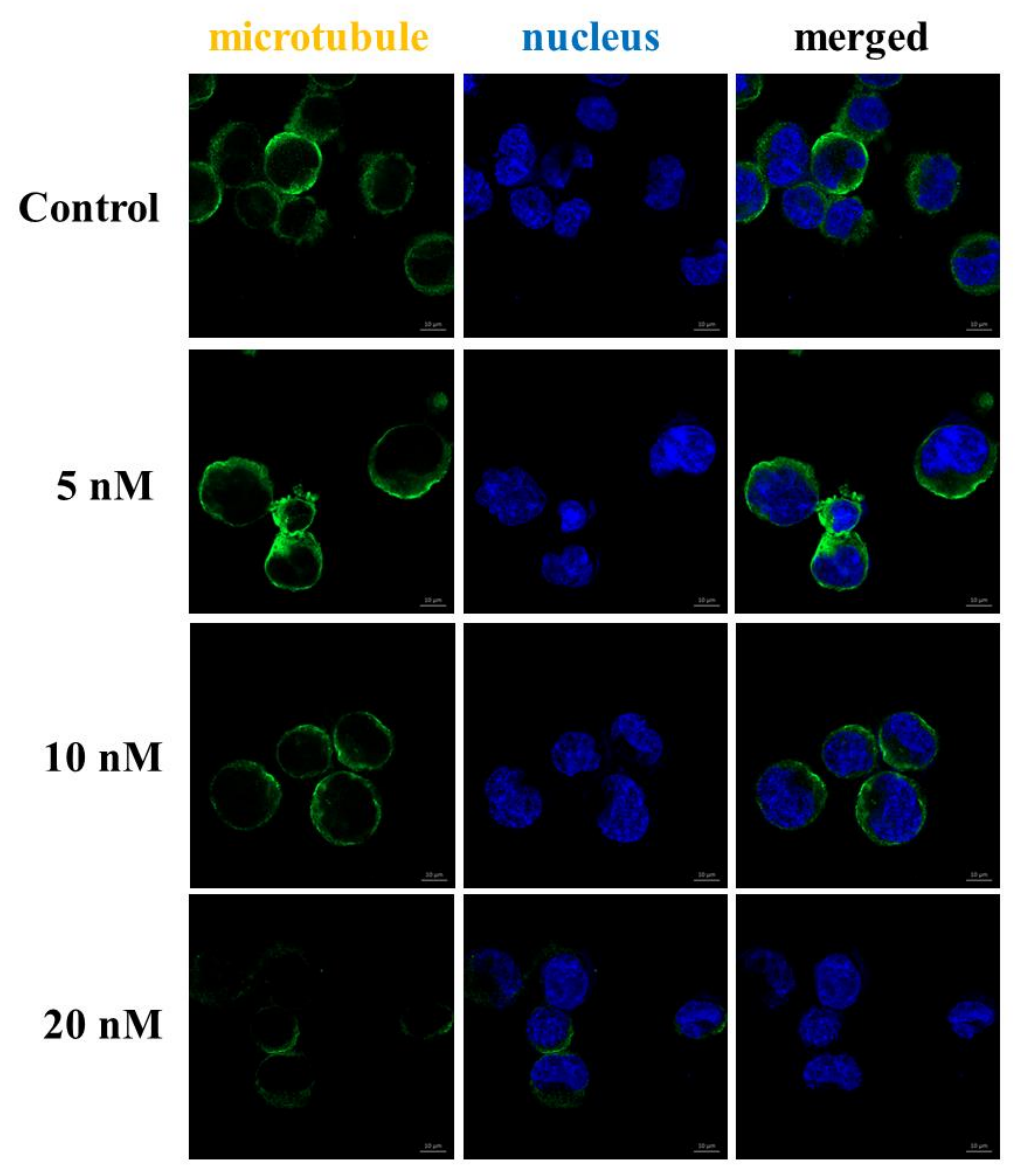

Figure 5. Effects of $\mathbf{2 4 d}$ on the cellular microtubule network visualized by immunofluorescence. 
K562 cells were treated with vehicle control 0.1\% DMSO, 24d (5 nM, $10 \mathrm{nM}$, and $20 \mathrm{nM})$. Then, the cells were fixed and stained with anti- $\alpha$-tubulin-FITC antibody (green), Alexa Fluor 488 dye and counterstained with DAPI (blue). The detection of the fixed and stained cells was performed with an LSM 570 laser confocal microscope (Carl Zeiss, Germany).

Docking Studies of Compound 24d with Tubulin. To investigate the potential binding site of $\mathbf{2 4 d}$ with the tubulin-microtubule system, molecular modeling studies were performed. The crystal structure of tubulin complexed with CA-4 (PDB: 5lyj) ${ }^{42}$ was chosen as the docking protein. CA-4 was first redocked into the colchicine site with the resulting root mean square deviation (RMSD) value of $0.69 \AA$, which indicated our docking method was reasonable. As shown in Figure 6a, 24d adopted a very similar location with that of CA-4. The phenolic hydroxyl of $\mathbf{2 4 d}$ formed two hydrogen bonds with the residue Val 315 while the hydroxyl of CA-4 interacted with the residue Thr 179 . The $N-1$ atom on the quinoline moiety of $\mathbf{2 4 d}$ formed a hydrogen bond with the critical residue Cys 241, which was similar to the binding pose of compound 11 with tubulin. ${ }^{33}$ The C-2 methyl group of $\mathbf{2 4 d}$ pointed towards the deep pocket of the colchicine site, which might explain how the C-2 position tolerated a modification without a significant decrease in activity. Similarly, the parent compound 1 was also docked into the colchicine site, and the result showed that compound 1 and 24d adopted similar positions when binding to tubulin (Figure 6b). The docking results demonstrated that $\mathbf{2 4 d}$ binds to the colchicine site of tubulin resembling the binding mode of CA-4. 


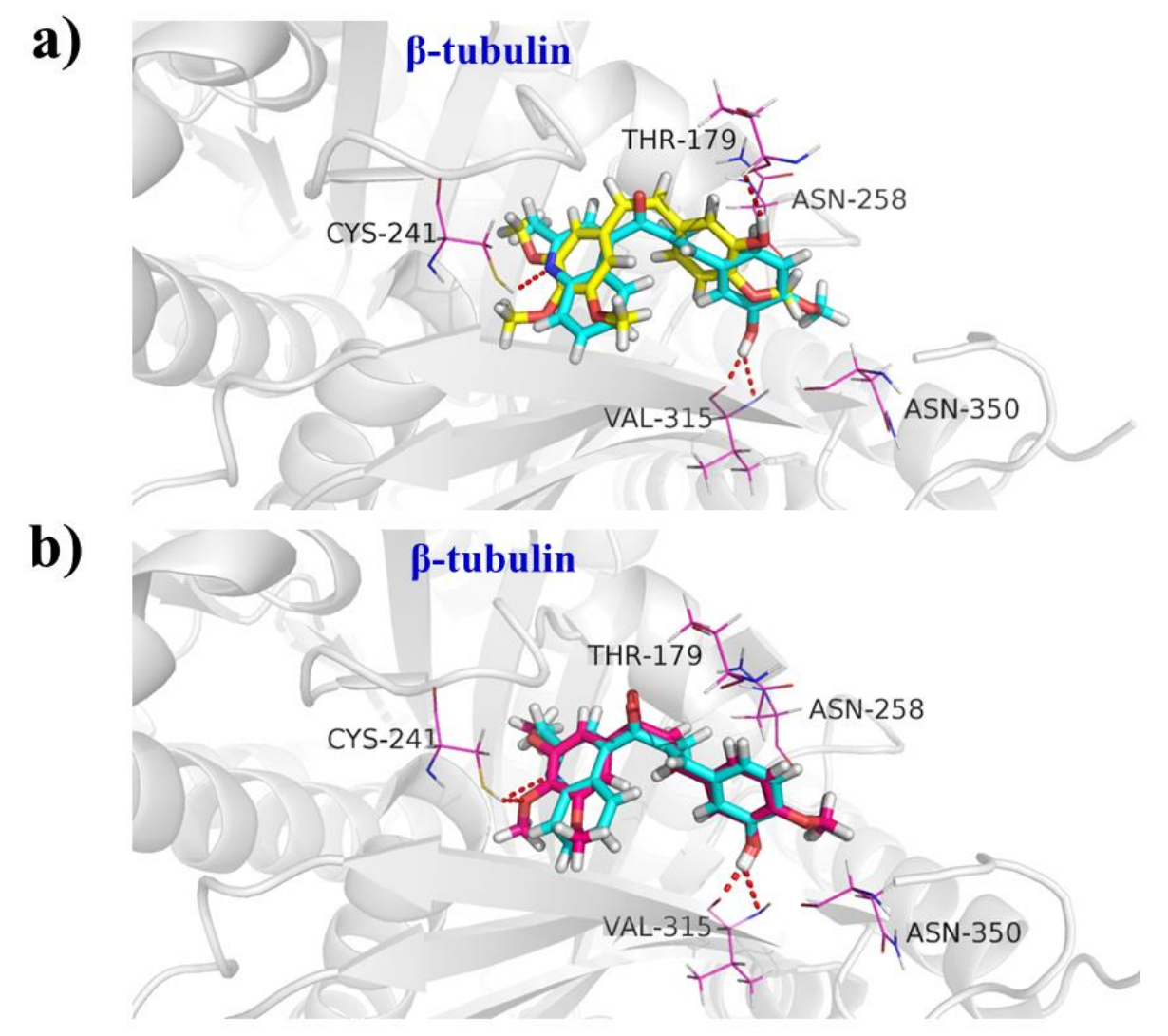

Figure 6. Proposed binding models for $24 d$ binding with tubulin (PDB code: 5lyj). (a) CA-4 (shown in yellow) and $\mathbf{2 4 d}$ (shown in cyan); (b) $\mathbf{1}$ (shown in pink) and $\mathbf{2 4 d}$ (shown in cyan).

\section{Compound 24d Induced G2/M Phase Arrest via Regulating G2/M-Related}

Protein Expression. Since most tubulin polymerization inhibitors could disrupt the regulated cell cycle distribution, ${ }^{43}$ a flow cytometry analysis was performed to examine the arrest effects of $\mathbf{2 4 d}$ on cell cycle of K562 cells. As illustrated in Figure $7 \mathrm{a}$ and $7 \mathrm{c}$, incubation with $\mathbf{2 4 d}$ arrested the cell cycle at the G2/M phase. The incubation of K562 cells with increasing concentrations of $\mathbf{2 4 d}$ from 0 to $30 \mathrm{nM}$ increased the percentage of cells in the G2/M phase from $15.82 \%$ to $26.98 \%$.

Mitosis in eukaryotic cells is regulated by the activation of Cdc2 kinase, which is controlled by several steps including cyclin B1 binding and cdc $25 \mathrm{c}$ phosphorylation. ${ }^{44}$ 
Thus, to obtain insight into the mechanism of $\mathbf{2 4 d}$ in K562 cell cycle arrest, the expression of cell cycle regulatory proteins was investigated. As shown in Figure $7 \mathrm{~b}$ and 7d, 24d decreased cdc2, cyclin B1 and cdc25c protein levels in a concentration-dependent manner. The results suggested that the $\mathbf{2 4 d}$-induced G2/M arrest may be correlated with a change of expression of cdc2/cyclin B1 and cdc25c.

\section{Compound 24d Induced Apoptosis via Regulating of Apoptosis-related Protein}

Expressions. Mitotic arrest of tumor cells by microtubule targeting agents is generally associated with cellular apoptosis. ${ }^{45}$ Hoechst 33342 staining was first used to assess morphology changes of K562 cells, as shown in Figure 8a, K562 cells incubated with $\mathbf{2 4 d}(5,10$, and $20 \mathrm{nM})$ for $48 \mathrm{~h}$ displayed significant changes in cell morphology, such as nucleus fragmentation and chromatin condensation, indicating cell apoptosis. To further evaluate the capacity of $\mathbf{2 4 d}$ to induce apoptosis, Annexin-V/PI assay was performed with K562 cells. As shown in Figure 8b and 8d, after K562 cells were exposed to 5, 10, and $20 \mathrm{nM}$ of $\mathbf{2 4 d}$ for $48 \mathrm{~h}$, the total numbers of early (Annexin-V+/PI-) and late (Annexin-V+/PI+) apoptotic cells were 17.21\%, $34.55 \%$ and $60.14 \%$, respectively.

Increasing evidence has indicated that the regulation of the Bcl-2 family of proteins is involved in the signaling pathways, ${ }^{46}$ including pro-apoptotic (e.g., Bax and Bad) and anti-apoptotic proteins (e.g., Bcl-2 and Bcl-xl). As shown in Figure 8c and 8e, 24d upregulated Bad and Bax and downregulated Bcl-2 and Bcl-xl protein levels in a concentration-dependent manner. Thus, as described above, compound 24d induced cell apoptosis by interfering with the expression of apoptosis-related proteins. 

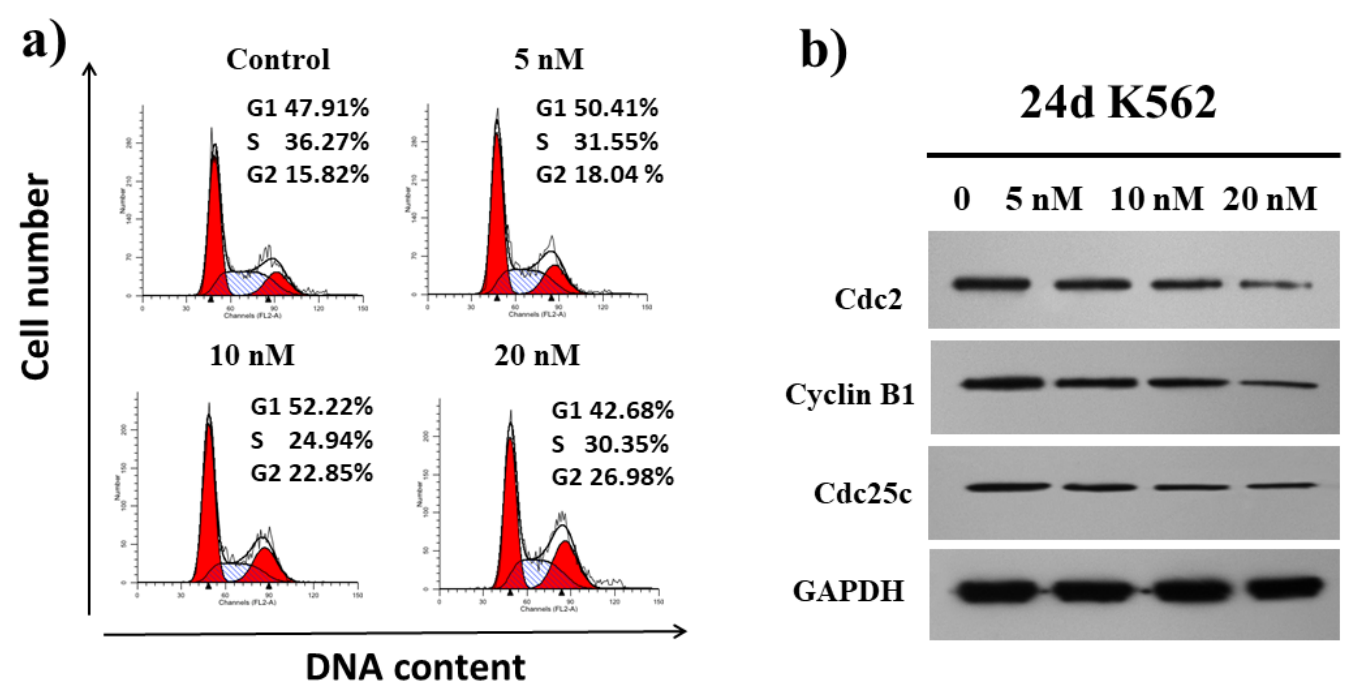

c)

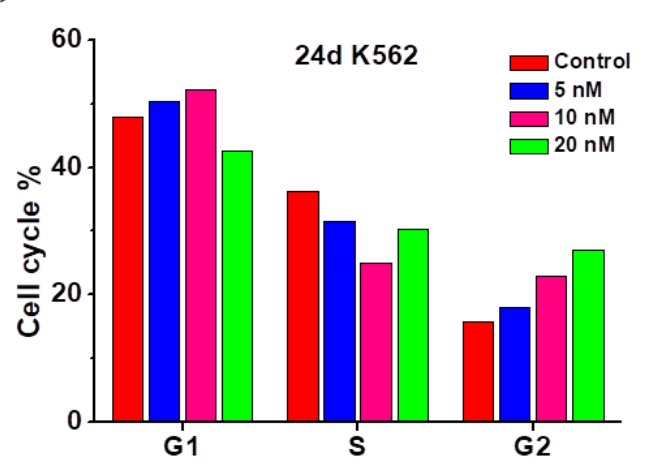

d)

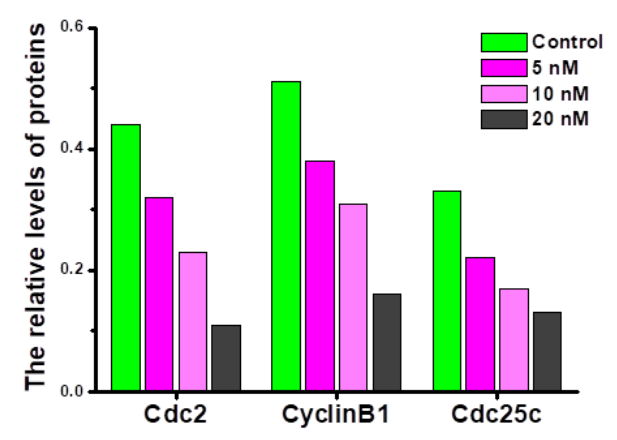

Figure 7. Compound 24d induced G2/M arrest in K562 cancer cells. (a) K562 cells were incubated with DMSO and varying concentrations of $\mathbf{2 4 d}(5,10$, and $20 \mathrm{nM})$ for $48 \mathrm{~h}$. Cells were harvested and stained with PI and then analyzed by flow cytometry. The percentages of cells in different phases of the cell cycle were analyzed by ModFit 4.1. (b) Western blotting analysis on the effect of $\mathbf{2 4 d}$ on the G2/M regulatory proteins. The cells were harvested and lysed for the detection of cdc2, cdc25c and cyclin B1. (c) Histograms display the percentage of cell cycle distribution. (d) Histograms display the density ratios of cdc2, cdc25c and cyclin B1 to GADPH. 


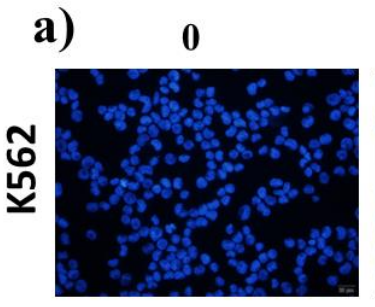

b)

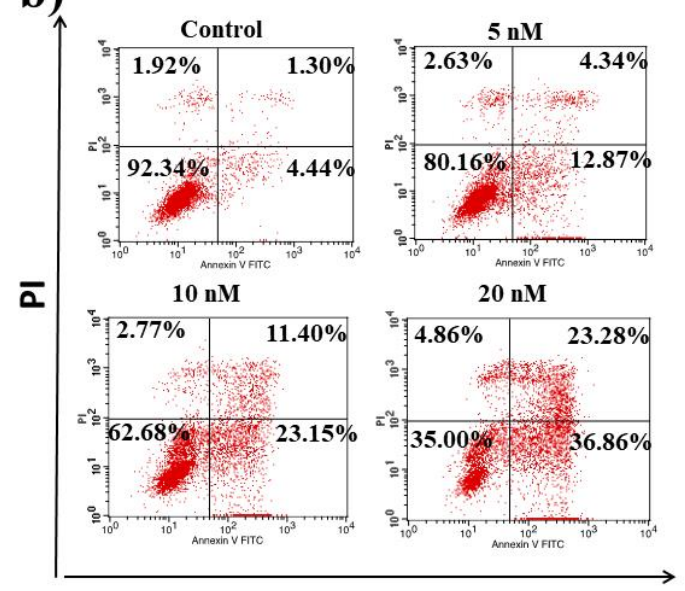

Annexin V

d)

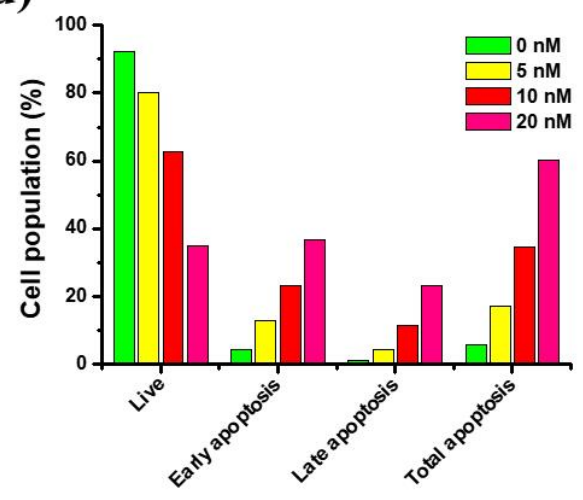

$10 \mathrm{nM}$

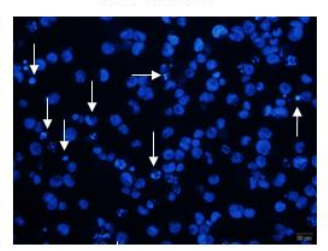

c)

\section{4d K562}

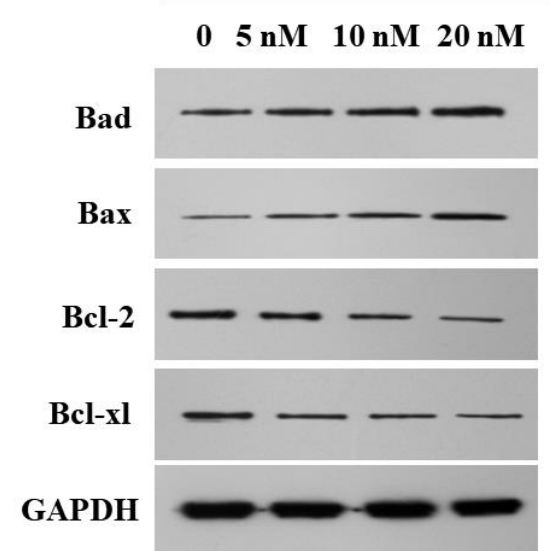

e)

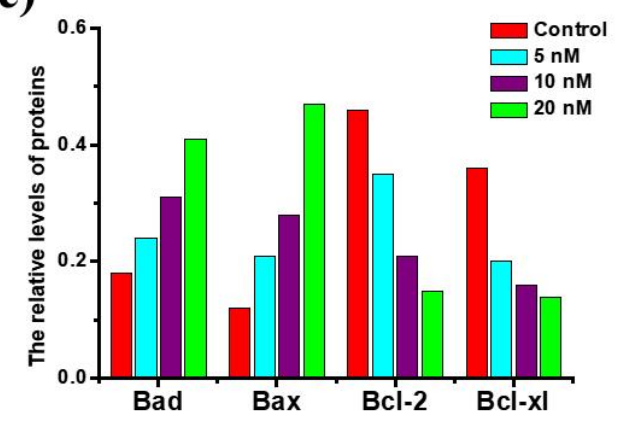

Figure 8. Compound 24d induced apoptosis in K562 cancer cells. (a) Cell morphological alterations and nuclear changes (white arrow marked cells) associated with K562 cells after incubation with $\mathbf{2 4 d}(5,10$, and $20 \mathrm{nM})$ for $48 \mathrm{~h}$ were assessed by staining with Hoechst 33342 and visualized by fluorescence microscopy; (b) K562 cells were incubated with DMSO and varying concentrations of $\mathbf{2 4 d}(5,10$, and $20 \mathrm{nM})$ for $48 \mathrm{~h}$, cells were collected and stained with Annexin V/PI, followed by flow cytometric analysis; (c) Western blotting analysis on the effect of 24d on apoptosis-related proteins. The cells were harvested and lysed to detect Bad, Bax, Bcl-2 
and Bcl-xl; (d) Histograms display the percentage of cell distribution; (e) Histograms display the density ratios of Bad, Bax, Bcl-2 and Bcl-xl to GADPH.

\section{Compound 24d Induced Mitochondrial Depolarization and Reactive Oxygen}

Species (ROS) Generation. Increasing evidence has indicated that mitochondria plays an important role in regulating cellular functions, and mitochondrial dysfunction is involved in many pathological processes. ${ }^{47}$ To explore whether $\mathbf{2 4 d}$ could induce mitochondrial dysfunction, mitochondrial membrane potential (MMP) assay by JC-1 staining of mitochondria in K562 was performed. As shown in Figure 9a, with the concentrations of $\mathbf{2 4 d}$ increasing from 0 to $20 \mathrm{nM}$, the green fluorescence intensity (JC-1 monomers, low mitochondrial membrane potentials) correspondingly increased from $0.63 \%$ to $53.39 \%$, suggesting that $\mathbf{2 4 d}$ caused MMP collapse of K562 cells and mitochondrial dysfunction, which eventually triggers apoptotic cell death.

Accumulating evidence reveals that increased levels of reactive oxygen species (ROS) is often associated with promoting cancer cell growth, ${ }^{47}$ and mitochondrial membrane depolarization is related to mitochondrial production of ROS. ${ }^{48}$ Thus, the fluorescent probe $2^{\prime}, 7^{\prime}$-dichlorofluorescein diacetate (DCF-DA) was used to evaluate the intracellular ROS levels after incubation with 24d. As shown in Figure 9b and 9c, 24d induced intracellular ROS generation with a dose-dependent manner, while the increased ROS was inhibited by pre-incubation with $2.5 \mathrm{mM}$ of the ROS scavenger, $N$-acetyl cysteine (NAC). 
a)

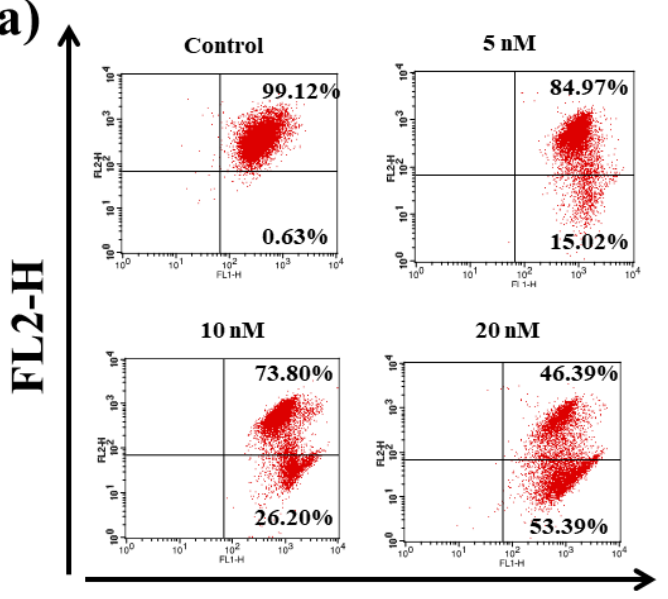

b)

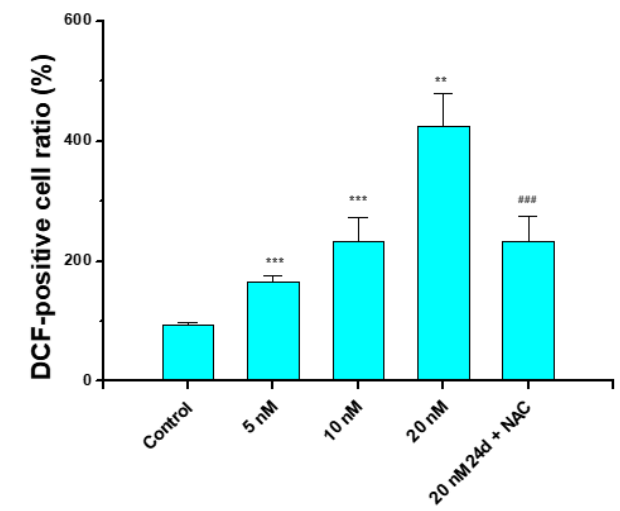

FL1-H

c) 24d K562

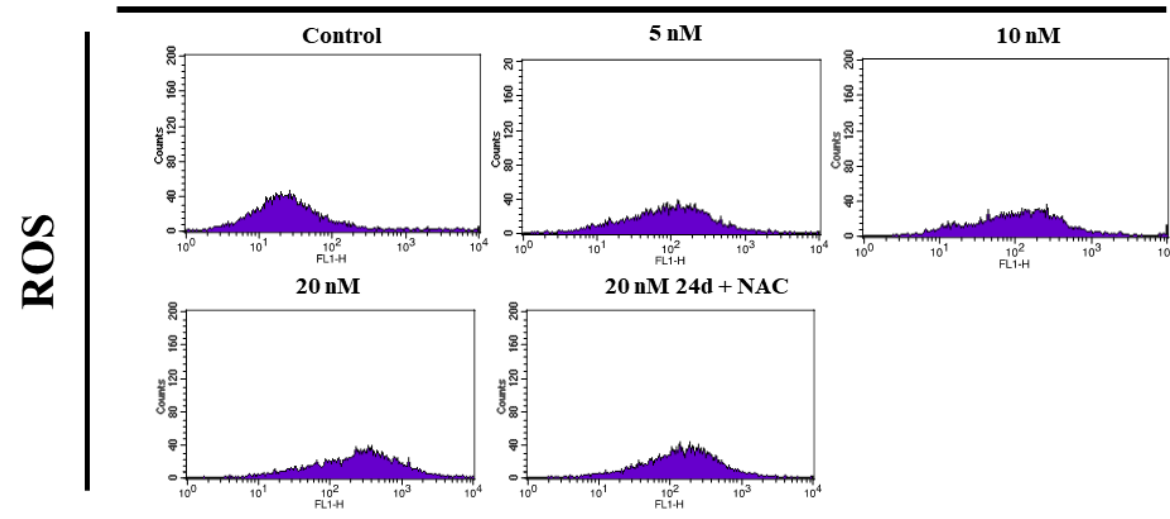

Figure 9. Effects of $\mathbf{2 4 d}$ on the mitochondrial membrane potential of K562 cells. a) After incubation with different concentrations $(0,5,10$ and $20 \mathrm{nM})$ of $\mathbf{2 4 d}$ in $\mathrm{K} 562$ cells for $48 \mathrm{~h}$ prior to staining with JC-1 dye, the number of cells with collapsed mitochondrial membrane potentials was determined by flow cytometry analysis; (b) Histograms display the intracellular ROS contents in the absence or presence of 24d. ${ }^{* *} p<0.01$, ***p $<0.001$ vs. control; \#\#\# $p<0.001 v s .20 \mathrm{nM}$ 24d-treated group; (c) The generation of ROS was measured using the ROS-detecting fluorescent dye DCF-DA in combination with FACScan flow cytometry.

\section{Compound 24d Inhibited the Migration and Invasion of MDA-MB-231 Cells.}

Cell migration and invasion play essential roles in achieving normal functions, such as wound healing and embryonic growth. ${ }^{49}$ Drugs that can simultaneously induce 
apoptosis and inhibit migration or invasion of cancer cells have clinical superiorities and have gained increasing research interest. ${ }^{50}$ To evaluate the ability of $\mathbf{2 4 d}$ in preventing the migration and invasion of cancer cells, transwell assays with or without Matrigel were conducted. The highly invasive and aggressive MDA-MB-231 cell line was chosen for activity evaluation. As shown in Figure 10a and 10b, 24d dose-dependently inhibited MDA-MB-231 cell migration through the membrane of the transwell insert after incubation with $\mathbf{2 4 d}(2,5$, and $10 \mathrm{nM})$ for $48 \mathrm{~h}$. In the invasion assay, 24d potently and dose-dependently inhibited cell invasion through the Matrigel-coated membrane (Figure 10c and 10d). These results indicated that 24d effectively inhibited the migration and invasion of MDA-MB-231 cells, which were not due to the cytotoxic actions of $\mathbf{2 4 d}$ (inhibitive rate under $10 \%$ after incubation with $\mathbf{2 4 d}$ at $10 \mathrm{nM}$ for $48 \mathrm{~h}$ ).
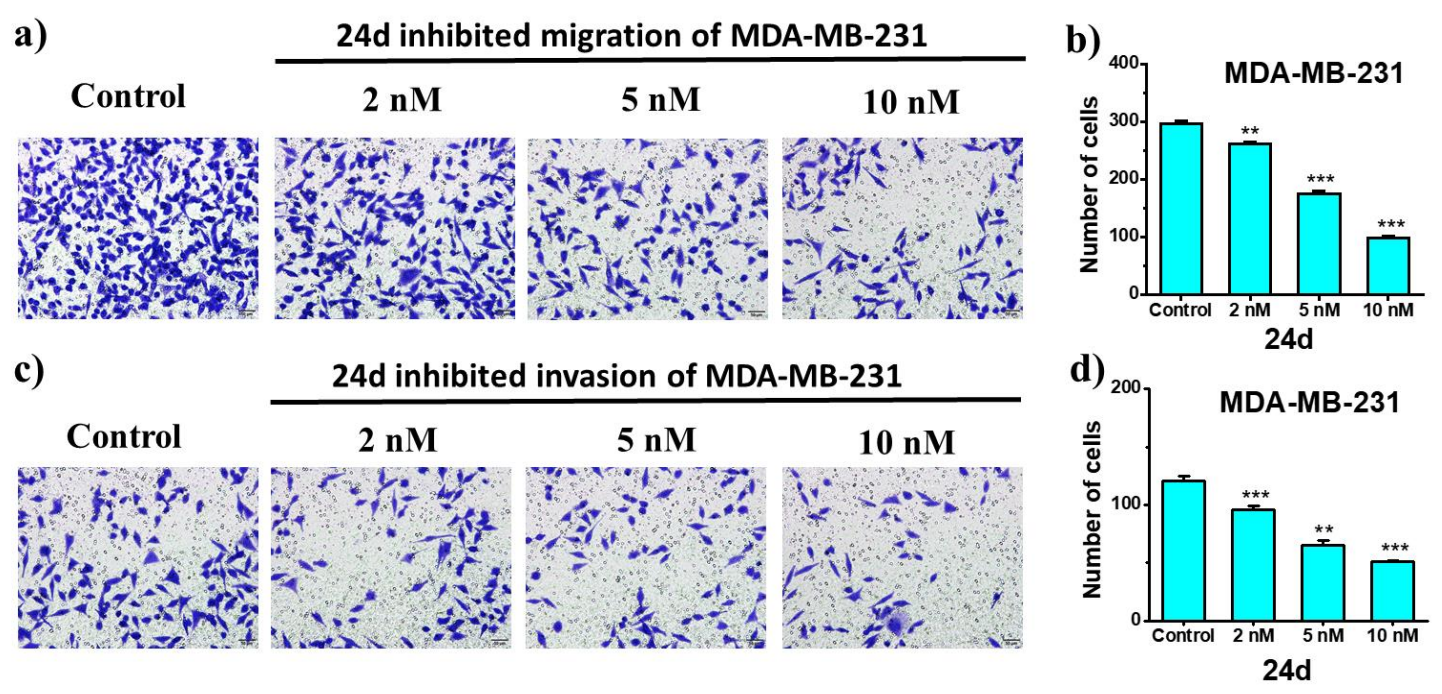

Figure 10. Effects of $\mathbf{2 4 d}$ on transwell migration and invasion of MDA-MB-231 cells. (a) The

MDA-MB-231 cells were seeded on chambers and incubated with $\mathbf{2 4 d}(0,2,5$, and $10 \mathrm{nM})$ for 48

h. Cells that migrated through the chambers were stained with crystal violet, and representative 
images were captured; (b) The cells that migrated through the chambers were counted from three independent experiments; (c) The MDA-MB-231 cells were seeded on chambers and and incubated with $24 \mathbf{d}(2,5$, and $10 \mathrm{nM})$ for $48 \mathrm{~h}$. Cells that migrated through the Matrigel-coated chambers were stained with crystal violet, and representative images were captured; (d) The cells that migrated through the Matrigel-coated chambers were counted from three independent experiments. All the data in (b and d) were expressed as the means \pm SD of each group of cells. $* * P<0.01, * * * P<0.001$ vs. control group.

Compound 24d Exhibited Potent Anti-Vascular Activity. Most microtubule binding agents possess potent vascular disrupting activity, which are contributed to the disruption of microtubule dynamics to induce endothelial cell shape change. ${ }^{51}$ As HUVEC migration is the key step to generate new blood vessels, ${ }^{52}$ wound healing assay was applied to assess the ability of $\mathbf{2 4 d}$ to inhibit HUVEC migration. As shown in Figure 11a and 11c, the untreated cells migrated to fill the area that was initially scraped after $24 \mathrm{~h}$, while 24d significantly inhibited HUVEC migration at the dose of $20 \mathrm{nM}$.

We also evaluated the effect of $\mathbf{2 4 d}$ in a tube formation assay, which are based on the ability of HUVECs to form tubular and cord-like networks on Matrigel. In contrast to the tube-like networks of the control, the capillary-like tubes of HUVECs exposed to $\mathbf{2 4 d}$ at doses of 5,10 , and $20 \mathrm{nM}$ for $6 \mathrm{~h}$ could be interrupted at different levels (Figure 11b). These results showed that 24d effectively inhibited the tube formation of HUVECs.

The antiproliferative activity of $\mathbf{2 4 d}$ against HUVECs was also determined by an 
MTT assay to exclude the possibility that the anti-vascular activity of $\mathbf{2 4 d}$ was due to a cytotoxic action of $\mathbf{2 4 d}$. The calculated IC $_{50}$ value of $\mathbf{2 4 d}$ against HUVECs after a 24-h treatment was $0.250 \pm 0.06 \mu \mathrm{M}$, which is higher than the concentration of $10 \mathrm{nM}$ required for the obvious inhibition of cell migration and tube formation. These results indicate that $\mathbf{2 4 d}$ exhibited possessed anti-vascular activity.

Physicochemical Properties of $\mathbf{2 4 d}$. To evaluate the drug-likeness of $\mathbf{2 4 d}$, the physicochemical properties of $\mathbf{2 4 d}$ were predicted with compound $\mathbf{1}$ and CA-4 as the references. ${ }^{53}$ As shown in Table 5, compound 24d conformed to Lipinski's rule of five. The aqueous solubility in phosphate buffer $(\mathrm{pH} 7.4)$ was also determined at $20{ }^{\circ} \mathrm{C}$ by HPLC. ${ }^{54}$ As shown in Table 5 , the solubility of $\mathbf{2 4 d}$ was approximately 5and 16-fold greater than compounds 1 and CA-4, respectively. Moreover, the hydrochloride salt of $\mathbf{2 4 d}(\mathbf{2 4 d}-\mathbf{H C l})$ could be easily prepared by the reaction of $\mathbf{2 4 d}$ with hydrogen chloride in ethyl acetate, which was soluble in PBS (solubility > 1000 $\mu \mathrm{g} / \mathrm{mL})$. The improvement of the aqueous solubility of $\mathbf{2 4 d}$ is most likely attributable to the quinoline moiety, which is more water-soluble than trimethylphenyl ring in compounds 1 and CA-4.

Table 5. Aqueous Solubility in PBS (pH 7.4) and Physicochemical Properties of Compounds 1, CA-4, and 24d.

\begin{tabular}{ccccccc}
\hline Compd. & $\mathrm{MW}^{a}$ & $\mathrm{HBA}^{b}$ & $\mathrm{HBD}^{c}$ & $\operatorname{cLogP}^{d}$ & $\operatorname{tPSA}^{e}$ & Solubility $(\mu \mathrm{g} / \mathrm{mL})^{f}$ \\
\hline $\mathbf{1}$ & 344.13 & 6 & 1 & 2.78 & 74.23 & 3.2 \\
$\mathrm{CA}-4$ & 316.13 & 5 & 1 & 3.47 & 57.16 & 1.055 \\
$\mathbf{2 4 d}$ & 333.14 & 4 & 1 & 4.37 & 59.42 & 16.0 \\
\hline
\end{tabular}




\begin{tabular}{rcccccc}
\hline $\mathbf{2 4 d - H C l}$ & - & - & - & - & - & $>1000$ \\
$\operatorname{RO5}^{g}$ & $<450$ & $<10$ & $<5$ & $<5$ & $<90$ & \\
\hline
\end{tabular}

${ }^{a} \mathrm{MW}$ : molecular weight; ${ }^{b} \mathrm{HBA}$ : hydrogen-bond acceptor atoms; ${ }^{c} \mathrm{HBD}$ : hydrogen-bond donor atoms; ${ }^{d} \operatorname{cogP}$ : calculated logarithm of the octanol-water partition coefficient; ${ }^{e}$ PSA: topological polar surface area, calculated using http://www.molinspiration.com/cgi-bin/properties. ${ }^{f}$ Solubility in PBS (pH 7.4); ${ }^{g} \mathrm{RO}$ : Lipinski's rule of five.
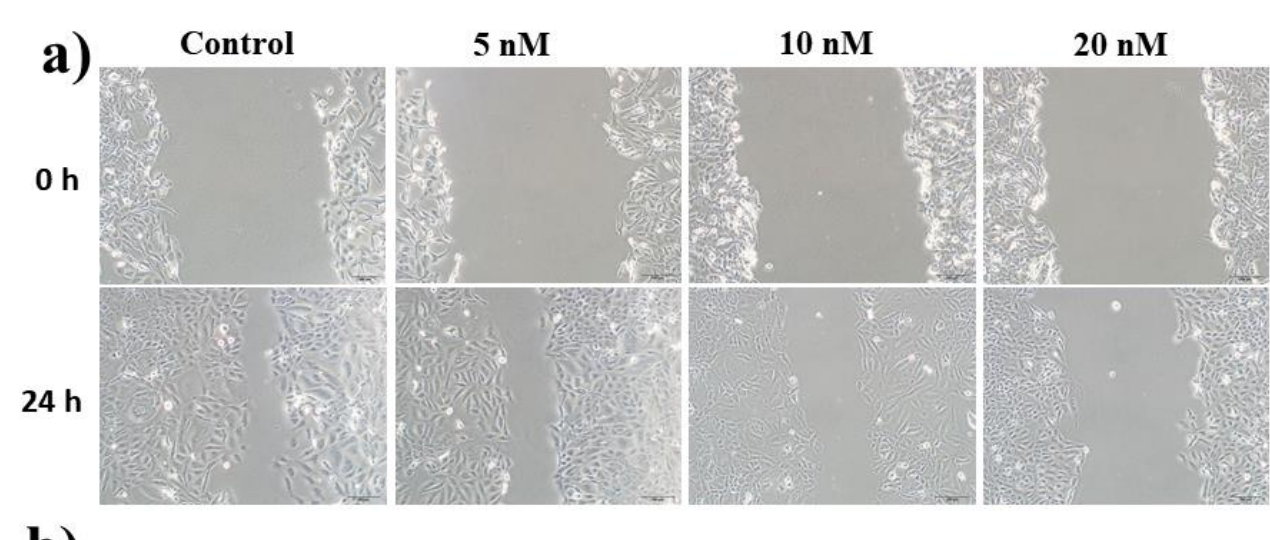

b)
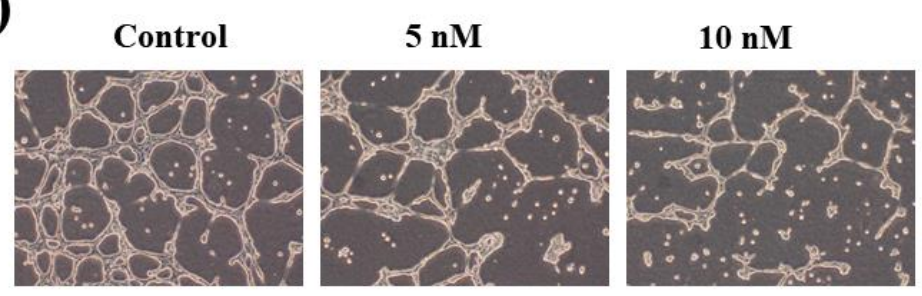

$20 \mathrm{nM}$

c)

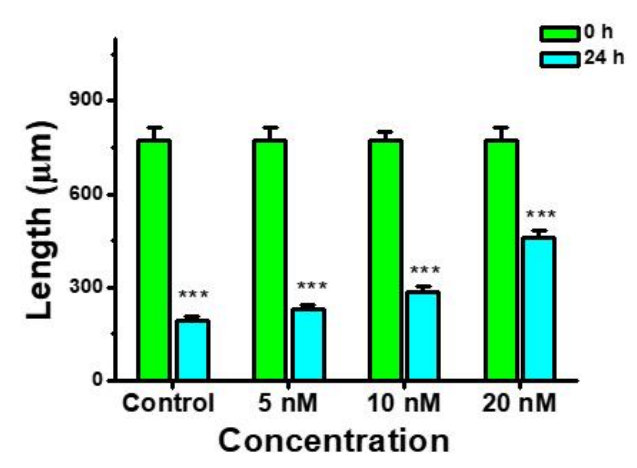

Figure 11. Effects on HUVECs migration and tube formation. (a) Scratches were created with sterile $200 \mu \mathrm{L}$ pipette tips, and images were captured using phase contrast microscopy at $0 \mathrm{~h}$ and $24 \mathrm{~h}$ after treatments with $0,5,10$ and $20 \mathrm{nM}$ of $\mathbf{2 4 d}$. (b) Images depicting the formation of a HUVEC capillary-like tubular network after treatments with 0, 5, 10 and $20 \mathrm{nM}$ of $\mathbf{2 4 d}$ for 6 h. (c) 
Histograms display the length of the scratches at $0 \mathrm{~h}$ and $24 \mathrm{~h}$ after treatments with $0,5,10$ and 20 $\mathrm{nM}$ of 24d, $* * * P<0.001 v s$. control group.

The Safety Profile of $\mathbf{2 4 d}$ in Mice. To investigate the safety profiles of $\mathbf{2 4 d}$, the acute toxicity was determined in ICR mice treated with 409.6, 512, 640, 800, and $1000 \mathrm{mg} / \mathrm{kg}$ ( $i v, \mathrm{n}=10$ per group) for 14 days. As shown in Table 6, treatment with 24d at doses of $409.6 \mathrm{mg} / \mathrm{kg}$ only caused one death in ten mice, while treatment with 24d at $1000 \mathrm{mg} / \mathrm{kg}$ killed nine mice. Finally, the median lethal dose $\left(\mathrm{LD}_{50}\right)$ value of 24d was calculated to be $665.62 \mathrm{mg} / \mathrm{kg}$, indicating the low toxicity of $\mathbf{2 4 d}$ and its safety as an anti-tumor agent.

Table 6. Acute Toxicity of $\mathbf{2 4 d}$ in Mice.

\begin{tabular}{ccccc}
\hline dose $(\mathrm{mg} / \mathrm{kg})$ & no. of mice & total mortality & survival $(\%)$ & $\mathrm{LD}_{50}(\mathrm{mg} / \mathrm{kg})^{a}$ \\
\hline 409.6 & 10 & 1 & 90 & \\
512 & 10 & 2 & 80 & \\
640 & 10 & 4 & 60 & 665.62 \\
800 & 10 & 7 & 30 & \\
1000 & 10 & 9 & 10 & \\
${ }^{a}$ The $95 \%$ confidence limits: $624.01-710.02 \mathrm{mg} / \mathrm{kg}$. & \\
\hline
\end{tabular}

24d and 24d-HCl Inhibited the Growth of H22 Xenograft Tumors in Mice. The

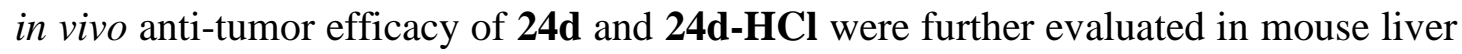
cancer xenograft models, which were established by subcutaneous inoculation of H22 cells into the right flank of mice. Once the tumors were well-established, the mice 
were randomly allocated into eight groups: vehicle (iv, group 1), paclitaxel (PTX) (iv, $8 \mathrm{mg} / \mathrm{kg}$ per 2 days, group 2), 24d (iv, $10 \mathrm{mg} / \mathrm{kg}$ per day, group 3), 24d (iv, $20 \mathrm{mg} / \mathrm{kg}$ per day, group 4), 24d-HCl (iv, $10 \mathrm{mg} / \mathrm{kg}$ per day, group 5), 24d-HCl (iv, $20 \mathrm{mg} / \mathrm{kg}$ per day, group 6), CA-4 (iv, $10 \mathrm{mg} / \mathrm{kg}$ per day, group 7), and CA-4 (iv, $20 \mathrm{mg} / \mathrm{kg}$ per day, group 8), with eight mice per group (Figure 12a). As shown in Figure 12b and 12d, 24d and 24d-HCl significantly and dose-dependently decreased tumor volume and tumor weight. At the $20 \mathrm{mg} / \mathrm{kg}$ dose, $\mathbf{2 4 d}-\mathbf{H C l}$ reduced the tumor weight by 68.9\%, which was more potent than the free drug 24d (65.3\%). Although CA-4 displayed comparable in vitro antiproliferative activity to $\mathbf{2 4 d}$, its anti-tumor activity (inhibition rate: $55.3 \%$ at $20 \mathrm{mg} / \mathrm{kg}$ ) was less potent than $\mathbf{2 4 d}$. Additionally, PTX exhibited potent activity with an inhibition rate of $90.4 \%$ at a dose of $8 \mathrm{mg} / \mathrm{kg}$ every 2 days. However, PTX-treated mice displayed significant decrease of body weight compared to those in control group (Figure 12c) while $\mathbf{2 4 d}$ and $\mathbf{2 4 d - H C l}$ did not obviously affect the body weight at doses of 10 and $20 \mathrm{mg} / \mathrm{kg}$.

Furthermore, we also observed the impact of $\mathbf{2 4 d}$ on tumor microvessels in vivo by immunohistochemistry. Tumor vessels were stained with CD31, which is a prominent endothelial marker that binds specifically to blood microvessels. As shown in Figure 12e, 24d-treated group at the dose of $20 \mathrm{mg} / \mathrm{kg}$ displayed considerably lower tumor microvessel density (MVD) than the control group, indicating that $\mathbf{2 4 d}$ exhibited potent in vivo anti-vascular activity.

Additionally, H\&E staining of the heart, liver, spleen, lung and kidney collected at the end of the study also suggested no observable major organ-related toxicities 
(Figure 13). Overall, these data indicated that compound $\mathbf{2 4 d}$ was efficacious in inhibiting the growth of cancer in vivo with no observable toxicity. It deserves further evaluation as a safe anti-tumor agent.

\section{a)}

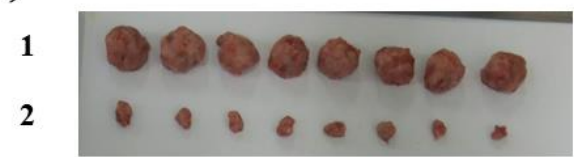

$300000 \%$

4

5

6

7

8

c)

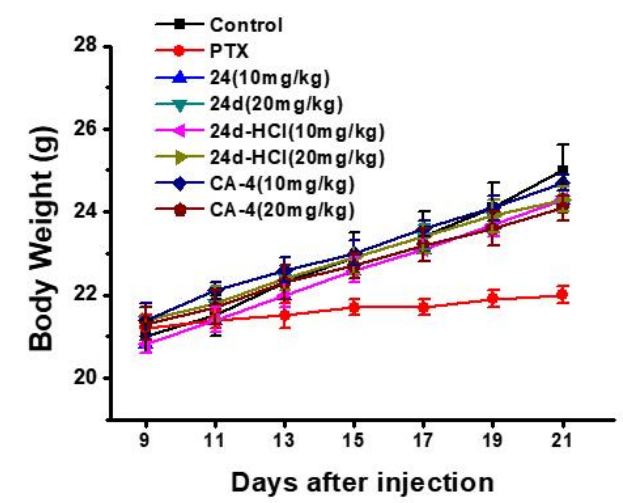

e)

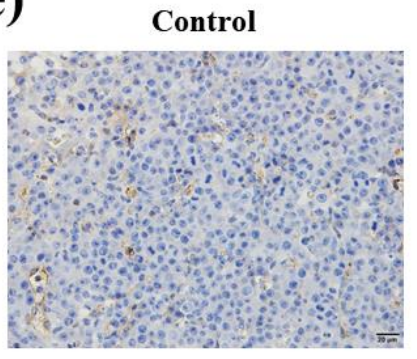

b)

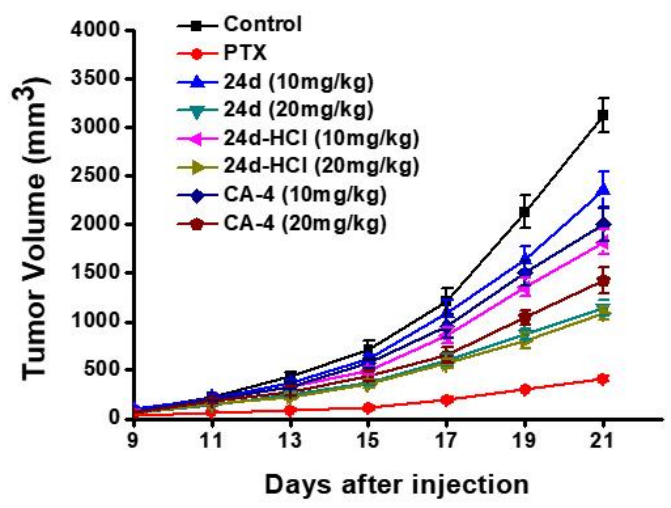

d)

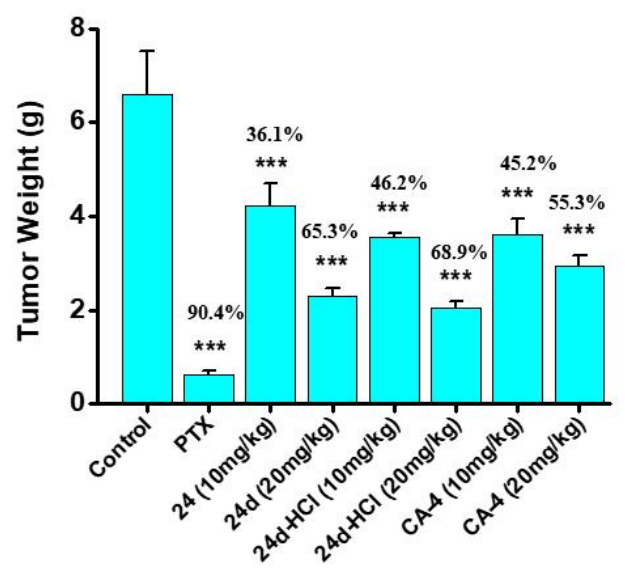

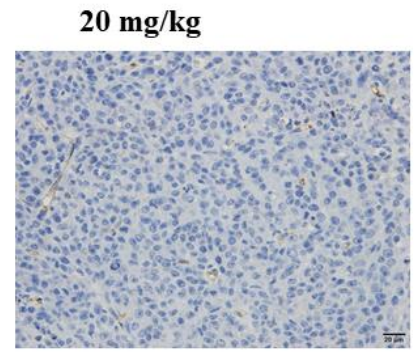

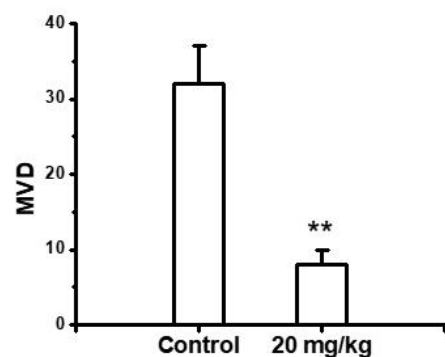

Figure 12. 24d inhibits liver cancer xenograft growth in vivo. After administering vehicle (group

1), PTX (8 mg/kg per 2 days, group 2), 24d (10 mg/kg per day, group 3), $24 d$ (20 mg/kg per day, 
$\mathrm{mg} / \mathrm{kg}$ per day, group 7), and CA-4 (20 mg/kg per day, group 8) for three weeks, the mice were sacrificed, and the tumors were weighed. (a) The images of tumors from mice at 21 days after initiation of treatment. (b) Tumor volume changes during treatment. (c) Body weight changes of mice during treatment. (d) The weight of the excised tumors of each group. $* * * P<0.001$ vs. control group. (e) Immunohistochemical staining against CD31 was used to quantify the microvessel density (MVD) in H22 xenograft tumors treated with vehicle and $\mathbf{2 4 d}(20 \mathrm{mg} / \mathrm{kg}$ ). Representative images of anti-CD31 immunohistochemistry from five tumor xenografts are shown. $* * P<0.01 v s$. control group.

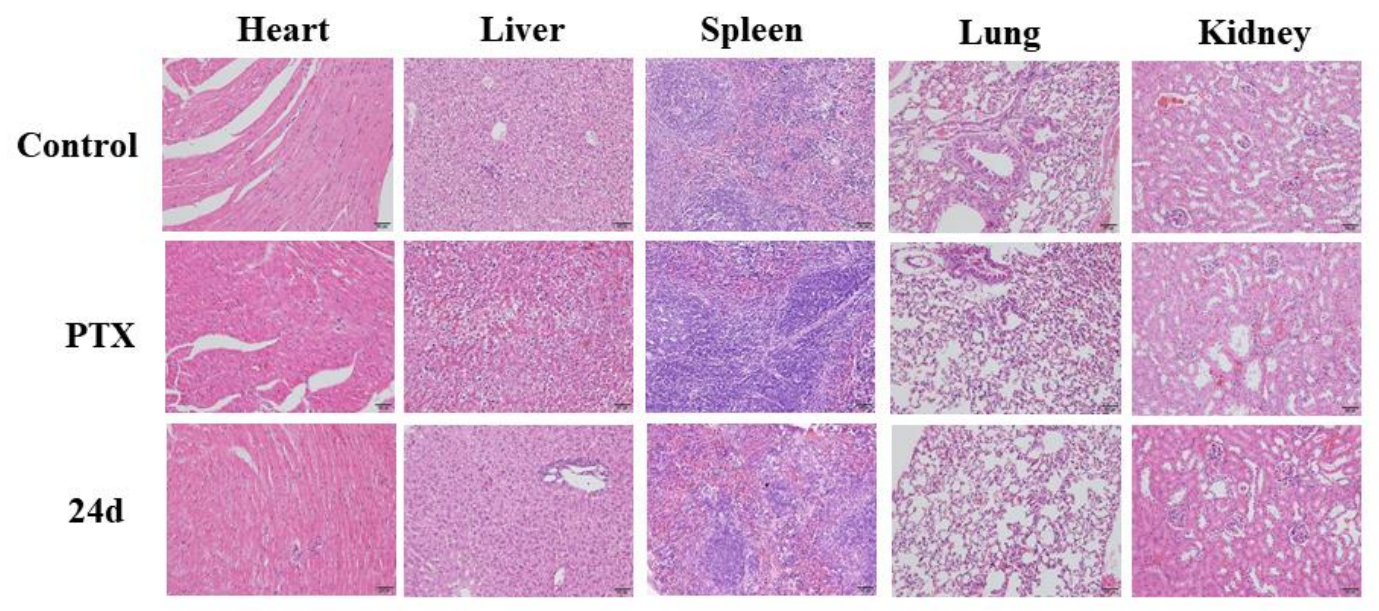

Figure 13. HE staining of heart, liver, spleen, lung and kidney of mice. No abnormality of these organs was observed.

\section{CONCLUSION}

Based on the previous work, we have continued to focus our studies on the new nitrogenous chalcones acting as CBSIs. With chalcone compound $\mathbf{1}$ as the parent compound, we designed and synthesized a series of novel quinoline-chalcone derivatives with comprehensive and detailed SARs. Some compounds displayed enhanced antiproliferative efficacy in a panel of human cancer cell lines, and the most 
potent compound $\mathbf{2 4 d}$ exhibited excellent antiproliferative activity with $\mathrm{IC}_{50}$ values ranging from 0.009 to $0.016 \mu \mathrm{M}$, which is comparable to those of the reference compound CA-4. Furthermore, 24d displayed a 65.8-fold selectivity ratio for normal human liver L-O2 cells, which was higher than that of CA-4, indicating that $\mathbf{2 4 d}$ might have lower toxicity than CA-4.

In addition, the microtubule polymerization inhibitory action of $\mathbf{2 4 d}$ was investigated using an in vitro tubulin polymerization assay, colchicine competition inhibition assay, immunofluorescence analysis of intracellular microtubules and a virtual molecular docking study. These experiments demonstrated that $\mathbf{2 4 d}$ effectively inhibited tubulin polymerization, and it bound to the colchicine site of tubulin. Further mechanistic studies indicated that $\mathbf{2 4 d}$ induced cell cycle arrest in the G2/M phase via regulation of G2/M-related protein expression ( $\operatorname{cdc} 2$, cyclin B1, and $\operatorname{cdc} 25 \mathrm{c}$ ) and induced cell apoptosis by upregulating the expression of pro-apoptotic protein (Bad and $\mathrm{Bax}$ ) and downregulating the expression of anti-apoptotic protein (Bcl-2 and Bcl-xl). Additionally, 24d depolarized the mitochondria membrane potentials and induced ROS generation in K562 cells.

Furthermore, 24d inhibited the migration and invasion of MDA-MB-231 cells in transwell migration and invasion assays, indicating the potent anti-metastatic activity of $\mathbf{2 4 d}$. The anti-vascular activity of $\mathbf{2 4 d}$ was confirmed in in vitro HUVECs migration and tube formation assays, and in vivo microvessel formation in $\mathrm{H} 22$ xenograft tumor issues. In addition, 24d displayed satisfactory physicochemical properties conforming to Lipinski's rule of five, and its aqueous solubility was greatly 
improved compared with compound $\mathbf{1}$ and CA-4. More importantly, 24d have a safety profile with an $\mathrm{LD}_{50}$ value of $665.62 \mathrm{mg} / \mathrm{kg}$ after $i v$. injection, and $\mathbf{2 4 d}$ and $\mathbf{2 4 d - H C l}$ exhibited potent anti-tumor activities in mouse liver cancer xenograft models without observable major organ-related toxicities. 24d effectively suppressed the tumor volume and reduced tumor weight by $65.3 \%$ at $20 \mathrm{mg} / \mathrm{kg}$ per day (iv). In the meantime, the more water-soluble hydrochloride salt $\mathbf{2 4 d - H C l}$ displayed a higher inhibition rate of $68.9 \%$ at $20 \mathrm{mg} / \mathrm{kg}$ per day $(i v)$, which is more potent than the reference CA-4.

Collectively, the new developed quinoline-chalcone derivative $\mathbf{2 4 d}$ has been shown to possess significant in vitro anti-metastatic activity, anti-vascular and anti-tumor activities both in vitro and in vivo. Thus, $\mathbf{2 4 d}$ has the potential to be further developed as an efficient chemotherapeutic agent.

\section{EXPERIMENTAL SECTION}

\section{Chemistry.}

1.1 General Methods. All commercially available reagents were used without further purification. Solvents were dried through routine protocols. Flash column chromatography was carried out on 200-300 mesh silica gel (Qingdao Haiyang Chemical, China). Reactions were monitored by thin-layer chromatography (TLC) on $0.25 \mathrm{~mm}$ silicagel plates (GF254) and visualized under UV light. ${ }^{1} \mathrm{H}$ NMR and ${ }^{13} \mathrm{C}$ NMR spectra were recorded with a Bruker AV-300 spectrometer (Bruker Company, Germany) in the indicated solvents $\left(\mathrm{CDCl}_{3}\right.$ or DMSO- $d_{6}, \mathrm{TMS}$ as internal standard): 
the values of the chemical shifts are expressed in $\delta$ values (ppm) and the coupling constants $(J)$ in Hz. Low- and high-resolution mass spectra (LRMS and HRMS) were measured on Finnigan MAT 95 spectrometer (Finnigan, Germany). Purity of all tested compounds was $\geq 95 \%$, as estimated by HPLC (SHIMADZU Labsolutions, UV dection at $\lambda=254 \mathrm{~nm})$ analysis on the Aglilent C18 column $(4.6 \times 150 \mathrm{~mm}, 5 \mu \mathrm{m})$.

1.2 1-(2-Methylquinolin-4-yl)ethan-1-one (16). 2-Methylquinoline-4-carboxylic acid (14) was synthesized according to literature report. ${ }^{56}$ To a solution of $\mathbf{1 4}$ (500 mg, $2.7 \mathrm{mmol}$ ) in $20 \mathrm{~mL}$ anhydrous $\mathrm{CH}_{2} \mathrm{Cl}_{2}$ was added dimethylamine hydrochloride (310 mg, $3.2 \mathrm{mmol})$, trimethylamine (440 $\mu \mathrm{L}, 3.2 \mathrm{mmol})$, EDCI (1.0 g, $5.4 \mathrm{mmol}), \mathrm{HOBt}$ (437.4 mg, $3.2 \mathrm{mmol}$ ) and catalytic amount of DMAP. The mixture was stirred for $2 \mathrm{~h}$, and extracted with $\mathrm{CH}_{2} \mathrm{Cl}_{2}(3 \times 50 \mathrm{~mL})$. The combined organic layers were then washed with brine, dried over anhydrous $\mathrm{Na}_{2} \mathrm{SO}_{4}$, and concentrated in vacuo to afford 15 as a yellow solid (510 mg, yield $83.1 \%$ ), which was used for next step without further purification. A solution of $\mathrm{CH}_{3} \mathrm{MgBr}$ in diethyl ether $(3 \mathrm{M}, 2.0 \mathrm{~mL}, 5.9 \mathrm{mmol})$ was added dropwise to a solution of $\mathbf{1 5}(500 \mathrm{mg}, 2.7 \mathrm{mmol})$ in $20 \mathrm{~mL}$ anhydrous THF under nitrogen atmosphere at $0{ }^{\circ} \mathrm{C}$. After stirring for $2 \mathrm{~h}$, the reaction was quenched by $\mathrm{NH}_{4} \mathrm{Cl}$ aqueous, and extracted with $\mathrm{CH}_{2} \mathrm{Cl}_{2}(3 \times 50 \mathrm{~mL})$. The combined organic layers were then washed with brine, dried over anhydrous $\mathrm{Na}_{2} \mathrm{SO}_{4}$, and concentrated in vacuo to provide the crude product, which was purified by column chromatography with petroleum/ethyl acetate (2:1) to give 16 (420 mg, 84.0\%); ${ }^{1} \mathrm{H}$ NMR (300 MHz, $\left.\mathrm{CDCl}_{3}\right) \delta 8.39-8.31(\mathrm{~m}, 1 \mathrm{H}), 8.09-8.00(\mathrm{~m}, 1 \mathrm{H}), 7.76-7.65(\mathrm{~m}, 1 \mathrm{H}), 7.58-7.51(\mathrm{~m}$, 1H), $7.47(\mathrm{~s}, 1 \mathrm{H}), 2.78(\mathrm{~s}, 3 \mathrm{H}), 2.71(\mathrm{~s}, 3 \mathrm{H}) ;{ }^{13} \mathrm{C} \mathrm{NMR}\left(75 \mathrm{MHz}, \mathrm{CDCl}_{3}\right) \delta 201.38$, 
$158.40,148.87,143.07,129.81,129.16,127.27,125.22,121.91,120.70,30.04,25.34$

ESI-MS $m / z[\mathrm{M}+\mathrm{Na}]^{+} 208.1$.

1.3 2-Methylquinoline-4-carbaldehyde (19). Intermediate 18 was synthesized according to literature report. ${ }^{40}$ To a solution of $\mathbf{1 8}(15.0 \mathrm{~g}, 86.7 \mathrm{mmol})$ in $50 \mathrm{~mL}$ $\mathrm{CH}_{2} \mathrm{Cl}_{2}$ was added Dess-Martin reagent $(40.4 \mathrm{~g}, 95.3 \mathrm{mmol})$ in batches. The mixture was stirred for $2 \mathrm{~h}$, and quenched by $\mathrm{Na}_{2} \mathrm{~S}_{2} \mathrm{O}_{4}$ aqueous. The residue was extracted with EtOAc $(3 \times 50 \mathrm{~mL})$, and the combined organic layers were then washed with saturated $\mathrm{NaHCO}_{3}$, brine, dried over anhydrous $\mathrm{Na}_{2} \mathrm{SO}_{4}$, and concentrated in vacuo to afford the crude product, which was purified by column chromatography with petroleum/ethyl acetate (2:1) to give $19(12 \mathrm{~g}, 80.0 \%) ;{ }^{1} \mathrm{H} \mathrm{NMR}\left(300 \mathrm{MHz}, \mathrm{CDCl}_{3}\right) \delta$ $10.42(\mathrm{~s}, 1 \mathrm{H}), 8.91(\mathrm{~d}, J=8.4 \mathrm{~Hz}, 1 \mathrm{H}), 8.09(\mathrm{~d}, J=8.5 \mathrm{~Hz}, 1 \mathrm{H}), 7.80-7.71(\mathrm{~m}, 1 \mathrm{H})$, $7.62(\mathrm{~d}, J=4.3 \mathrm{~Hz}, 2 \mathrm{H}), 2.83(\mathrm{~s}, 3 \mathrm{H}) ;{ }^{13} \mathrm{C} \mathrm{NMR}\left(75 \mathrm{MHz}, \mathrm{CDCl}_{3}\right) \delta$ 192.92, 159.09, 148.96, 136.96, 130.08, 129.15, 128.24, 127.06, 124.18, 122.15, 25.22; ESI-MS m/z $[\mathrm{M}+\mathrm{Na}]^{+}$194.1.

1.4 1-(2-Methylquinolin-4-yl)propan-1-one (21). A solution of $\mathrm{C}_{2} \mathrm{H}_{5} \mathrm{MgBr}$ in diethyl ether (3 M, $12 \mathrm{~mL}, 36.0 \mathrm{mmol})$ was added dropwise to a solution of 19 (5.0 g, $29.1 \mathrm{mmol}$ ) in $50 \mathrm{~mL}$ anhydrous THF under nitrogen atmosphere at $0{ }^{\circ} \mathrm{C}$. After stirring for $2 \mathrm{~h}$, the reaction was quenched by $\mathrm{NH}_{4} \mathrm{Cl}$ aqueous, and extracted with $\mathrm{CH}_{2} \mathrm{Cl}_{2}(3 \times 50 \mathrm{~mL})$. The combined organic layers were then washed with brine, dried over anhydrous $\mathrm{Na}_{2} \mathrm{SO}_{4}$, and concentrated in vacuo to provide the crude product, which was purified by column chromatography with petroleum/ethyl acetate $(2: 1)$ to give intermediate $20(4.3 \mathrm{~g}, 74.1 \%)$. To a solution of $\mathbf{2 0}(2.0 \mathrm{~g}, 9.95 \mathrm{mmol})$ in $50 \mathrm{~mL}$ 
$\mathrm{CH}_{2} \mathrm{Cl}_{2}$ was added Dess-Martin reagent $(5.1 \mathrm{~g}, 11.9 \mathrm{mmol})$ in batches. The mixture was stirred for $2 \mathrm{~h}$, and quenched by $\mathrm{Na}_{2} \mathrm{~S}_{2} \mathrm{O}_{4}$ aqueous. The residue extracted with EtOAc $(3 \times 50 \mathrm{~mL})$, and the combined organic layers were then washed with saturated $\mathrm{NaHCO}_{3}$, brine, dried over anhydrous $\mathrm{Na}_{2} \mathrm{SO}_{4}$, and concentrated in vacuo to afford the crude product, which was purified by column chromatography with petroleum/ethyl acetate (2:1) to give $21(1.3 \mathrm{~g}, 65.1 \%) .{ }^{1} \mathrm{H} \mathrm{NMR}\left(300 \mathrm{MHz}, \mathrm{CDCl}_{3}\right) \delta$ $8.16(\mathrm{~d}, J=8.5 \mathrm{~Hz}, 1 \mathrm{H}), 8.03(\mathrm{~d}, J=8.5 \mathrm{~Hz}, 1 \mathrm{H}), 7.73-7.65(\mathrm{~m}, 1 \mathrm{H}), 7.55-7.48(\mathrm{~m}$, 1H), $7.38(\mathrm{~s}, 1 \mathrm{H}), 3.01$ (q, $J=7.5 \mathrm{~Hz}, 2 \mathrm{H}), 2.76(\mathrm{~s}, 3 \mathrm{H}), 1.25(\mathrm{t}, J=7.2 \mathrm{~Hz}, 3 \mathrm{H}) ;{ }^{13} \mathrm{C}$ NMR (75 MHz, $\left.\mathrm{CDCl}_{3}\right) \delta 158.38,148.70,144.14,136.94,129.85,129.15,127.08$, $125.05,122.09,119.70,35.85,25.38,8.05 ;$ ESI-MS $m / z . \mathrm{M}+\mathrm{Na}]^{+} 222.1$.

1.5 General procedures for the preparation of $24 \mathrm{a}$ and $\mathbf{2 4 b}$. To a solution of 16 (75 mg, $0.40 \mathrm{mmol})$ or 21 (80 mg, $0.40 \mathrm{mmol})$ in $5 \mathrm{~mL}$ EtOH was added $\mathrm{NaOH}(81$ mg, $2.0 \mathrm{mmol}$ ). After stirring for $5 \mathrm{~min}$, 3-nitro-4-methoxybenzaldehyde ( $88 \mathrm{mg}, 0.49$ mmol) was added in one portion. After reaction completed, the mixture was extracted with EtOAc $(3 \times 20 \mathrm{~mL})$, and the combined organic layers were then washed with saturated brine, dried over anhydrous $\mathrm{Na}_{2} \mathrm{SO}_{4}$, and concentrated in vacuo to afford the crude products. The crude products were dissolved into the mixture solvent of $5 \mathrm{~mL}$ EtOH and $5 \mathrm{~mL} \mathrm{AcOH}, \mathrm{Fe}$ powder $(77 \mathrm{mg}, 1.38 \mathrm{mmol})$ was added, and the mixture was stirred at $65{ }^{\circ} \mathrm{C}$ for $30 \mathrm{~min}$. Then, the solvent was removed in vacuo, and the residue was neutralized by saturated $\mathrm{NaHCO}_{3}$ aqueous. The mixture was filtrated, and the filtrates was extracted with EtOAc $(3 \times 20 \mathrm{~mL})$, and the combined organic layers were then washed with saturated brine, dried over anhydrous $\mathrm{Na}_{2} \mathrm{SO}_{4}$, and 
concentrated in vacuo to afford the crude products, which was purified by column chromatography with petroleum/ethyl acetate (2:1) to give $\mathbf{2 4 a}$ or $\mathbf{2 4 b}$.

(E)-3-(3-amino-4-methoxyphenyl)-1-(2-methylquinolin-4-yl)prop-2-en-1-one (24a). Yellow solid (54 mg, yield $42.5 \%$ over two steps). ${ }^{1} \mathrm{H}$ NMR (300 MHz, $\mathrm{CDCl}_{3}$ ) $\delta 8.07(\mathrm{~d}, J=8.5 \mathrm{~Hz}, 1 \mathrm{H}), 8.03-7.95(\mathrm{~m}, 1 \mathrm{H}), 7.70(\mathrm{ddd}, J=8.4,6.8,1.5 \mathrm{~Hz}, 1 \mathrm{H})$, $7.51-7.45(\mathrm{~m}, 1 \mathrm{H}), 7.37(\mathrm{~d}, J=17.0 \mathrm{~Hz}, 2 \mathrm{H}), 7.00(\mathrm{~d}, J=16.0 \mathrm{~Hz}, 1 \mathrm{H}), 6.94-6.85$ $(\mathrm{m}, 2 \mathrm{H}), 6.75(\mathrm{~d}, J=8.2 \mathrm{~Hz}, 1 \mathrm{H}), 3.86(\mathrm{~s}, 3 \mathrm{H}), 2.78(\mathrm{~s}, 3 \mathrm{H}) ;{ }^{13} \mathrm{C}$ NMR $(75 \mathrm{MHz}$, CDCl3) $\delta 195.10,158.43,150.23,148.66,148.41,145.59,136.80,129.86,129.10$, $127.11,126.66,125.24,124.00,123.01,121.40,119.94,113.21,110.21,77.47,77.05$, 76.63, 55.62, 25.42; HR-MS (ESI) $m / z$ : calcd for $\mathrm{C}_{21} \mathrm{H}_{21} \mathrm{~N}_{2} \mathrm{O}_{2}[\mathrm{M}+\mathrm{H}]^{+}$319.1441, found 319.1445; Purity: 95.2\% (by HPLC).

(E)-3-(3-amino-4-methoxyphenyl)-2-methyl-1-(2-methylquinolin-4-yl)prop-2-e

n-1-one (24b). Yellow solid (65 mg, yield 50.4\% over two steps). ${ }^{1} \mathrm{H}$ NMR (300 MHz, $\left.\mathrm{CDCl}_{3}\right) \delta 8.00(\mathrm{~d}, J=8.5 \mathrm{~Hz}, 1 \mathrm{H}), 7.64(\mathrm{~m}, 2 \mathrm{H}), 7.39(\mathrm{t}, J=7.4 \mathrm{~Hz}, 1 \mathrm{H}), 7.17(\mathrm{~d}, J=$ $9.8 \mathrm{~Hz}, 1 \mathrm{H}), 6.97(\mathrm{~s}, 1 \mathrm{H}), 6.84-6.56(\mathrm{~m}, 3 \mathrm{H}), 3.79(\mathrm{~s}, 3 \mathrm{H}), 2.70(\mathrm{~s}, 3 \mathrm{H}), 2.28(\mathrm{~s}, 3 \mathrm{H})$; ${ }^{13} \mathrm{C}$ NMR $\left(75 \mathrm{MHz}, \mathrm{CDCl}_{3}\right) \delta 198.29,157.71,148.04,147.56,147.05,146.18,135.72$, $134.76,129.35,128.50,127.69,125.95,124.78,123.32,121.43,119.44,115.79$, 109.56, 55.05, 29.17, 24.83; HR-MS (ESI) $m / z$ : calcd for $\mathrm{C}_{21} \mathrm{H}_{21} \mathrm{~N}_{2} \mathrm{O}_{2}[\mathrm{M}+\mathrm{H}]^{+}$ 333.1598, found 333.1604. Purity: 98.2\% (by HPLC).

1.6 General procedures for the preparation of $24 \mathrm{c}$ and $24 \mathrm{~d}$. To a solution of 16 (75 $\mathrm{mg}, 0.40 \mathrm{mmol})$ or $21(80 \mathrm{mg}, 0.40 \mathrm{mmol})$ in $5 \mathrm{~mL} \mathrm{EtOH}$ was added $\mathrm{NaOH}(81 \mathrm{mg}$, $2.0 \mathrm{mmol})$. After stirring for $5 \mathrm{~min}$, MEM protected isovanillin $(117 \mathrm{mg}, 0.49 \mathrm{mmol})$ 
was added in one portion. After reaction completed, the mixture was extracted with EtOAc $(3 \times 20 \mathrm{~mL})$, and the combined organic layers were then washed with saturated brine, dried over anhydrous $\mathrm{Na}_{2} \mathrm{SO}_{4}$, and concentrated in vacuo to afford the crude products, which was purified by column chromatography with petroleum/ethyl acetate (4:1) to give products as colorless oil. Then, the products were dissolved in 5 $\mathrm{mL}$ EtOH, $1 \mathrm{~mL} \mathrm{10 \%} \mathrm{HCl}$ aqueous was added followed by refluxing for $30 \mathrm{~min}$. Then, the mixture was extracted with EtOAc $(3 \times 20 \mathrm{~mL})$, and the combined organic layers were then washed with saturated brine, dried over anhydrous $\mathrm{Na}_{2} \mathrm{SO}_{4}$, and concentrated in vacuo to afford the crude products, which was purified by column chromatography with petroleum/ethyl acetate (2:1) to give products $\mathbf{2 4} \mathbf{c}$ or $\mathbf{2 4 d}$.

(E)-3-(3-hydroxy-4-methoxyphenyl)-1-(2-methylquinolin-4-yl)prop-2-en-1-one (24c). Yellow solid (65 mg, 50.3\% over two steps). ${ }^{1} \mathrm{H}$ NMR (300 MHz, DMSO- $\left.d_{6}\right) \delta$ $9.26(\mathrm{~s}, 1 \mathrm{H}), 8.03(\mathrm{~d}, J=9.0 \mathrm{~Hz}, 2 \mathrm{H}), 7.76(\mathrm{t}, J=7.6 \mathrm{~Hz}, 1 \mathrm{H}), 7.65(\mathrm{~s}, 1 \mathrm{H}), 7.57(\mathrm{t}, J$ $=7.9 \mathrm{~Hz}, 1 \mathrm{H}), 7.50(\mathrm{~d}, J=16.0 \mathrm{~Hz}, 1 \mathrm{H}), 7.33-7.22(\mathrm{~m}, 2 \mathrm{H}), 7.20(\mathrm{~d}, J=6.3 \mathrm{~Hz}, 1 \mathrm{H})$, $6.97(\mathrm{~d}, J=8.4 \mathrm{~Hz}, 1 \mathrm{H}), 3.83(\mathrm{~s}, 3 \mathrm{H}), 2.74(\mathrm{~s}, 3 \mathrm{H}) ;{ }^{13} \mathrm{C}$ NMR $\left(75 \mathrm{MHz}, \mathrm{DMSO}-d_{6}\right) \delta$ $193.80,158.59,150.87,147.82,147.55,146.77,144.27,129.66,128.80,126.94$ 126.61, 124.96, 123.60, 122.60, 122.37, 120.42, 114.68, 111.91, 55.65, 24.81; HR-MS (ESI) $m / z$ : calcd for $\mathrm{C}_{20} \mathrm{H}_{18} \mathrm{NO}_{3}[\mathrm{M}+\mathrm{H}]^{+} 320.1281$, found 320.1285 . Purity: $95.8 \%$ (by HPLC).

(E)-3-(3-hydroxy-4-methoxyphenyl)-2-methyl-1-(2-methylquinolin-4-yl)prop-2 -en-1-one (24d). Yellow solid (52 mg, 36.1\% over two steps). ${ }^{1} \mathrm{H}$ NMR (300 MHz, $\left.\mathrm{CDCl}_{3}\right) \delta 8.08(\mathrm{~d}, J=8.5 \mathrm{~Hz}, 1 \mathrm{H}), 7.76-7.67(\mathrm{~m} 2 \mathrm{H}), 7.47(\mathrm{t}, J=7.6 \mathrm{~Hz}, 1 \mathrm{H}), 7.24(\mathrm{~s}$, 
1H), 7.12 - $6.99(\mathrm{~m}, 2 \mathrm{H}), 6.94-6.78(\mathrm{~m}, 2 \mathrm{H}), 3.89(\mathrm{~s}, 3 \mathrm{H}), 2.77(\mathrm{~s}, 3 \mathrm{H}), 2.35(\mathrm{~s}, 3 \mathrm{H})$;

${ }^{13} \mathrm{C}$ NMR $\left(75 \mathrm{MHz}, \mathrm{CDCl}_{3}\right) \delta 198.19,157.71,147.54,147.44,146.36,146.11,145.21$, $135.33,129.44,128.39,128.07,126.03,124.75,123.30,123.06,119.50,115.76$, $110.05,76.94,76.52,76.10,55.45,24.71,12.31$; HR-MS (ESI) $m / z$ : calcd for $\mathrm{C}_{21} \mathrm{H}_{20} \mathrm{NO}_{3}[\mathrm{M}+\mathrm{H}]^{+}$334.1438, found 334.1446. Purity: 99.3\% (by HPLC).

1.7 General procedures for the preparation of $24 \mathrm{e}-\mathrm{h}$. To a solution of 16 (75 mg, $0.40 \mathrm{mmol}$ ) or 21 (80 mg, $0.40 \mathrm{mmol})$ in $5 \mathrm{~mL}$ EtOH was added $\mathrm{NaOH}(81 \mathrm{mg}, 2.0$ mmol). After stirring for $5 \mathrm{~min}$, various benzaldehydes $(0.49 \mathrm{mmol})$ was added in one portion. After reaction completed, the mixture was extracted with EtOAc $(3 \times 20 \mathrm{~mL})$, and the combined organic layers were then washed with saturated brine, dried over anhydrous $\mathrm{Na}_{2} \mathrm{SO}_{4}$, and concentrated in vacuo to afford the crude products, which was purified by column chromatography with petroleum/ethyl acetate (2:1) to give $\mathbf{2 4 e - h}$.

(E)-3-(4-methoxyphenyl)-2-methyl-1-(2-methylquinolin-4-yl)prop-2-en-1-one

(24e). White solid (82 mg, 64.4\%). ${ }^{1} \mathrm{H}$ NMR (300 MHz, $\left.\mathrm{CDCl}_{3}\right) \delta 8.03-7.97(\mathrm{~m}, 1 \mathrm{H})$, 7.70 - 7.59 (m, 2H), 7.39 (m, 1H), $7.28(\mathrm{~s}, 1 \mathrm{H}), 7.25(\mathrm{~s}, 1 \mathrm{H}), 7.17$ (s, 1H), $7.06-7.02$ $(\mathrm{m}, 1 \mathrm{H}), 6.82(\mathrm{~d}, J=8.9 \mathrm{~Hz}, 2 \mathrm{H}), 3.74(\mathrm{~s}, 3 \mathrm{H}), 2.71(\mathrm{~s}, 3 \mathrm{H}), 2.29(\mathrm{~s}, 3 \mathrm{H}) . ;{ }^{13} \mathrm{C} \mathrm{NMR}$ $\left(75 \mathrm{MHz}, \mathrm{CDCl}_{3}\right) \delta 198.20,160.17,157.71,147.59,146.21,146.01,134.96,131.64$, $129.37,128.55,127.27,125.97,124.73,123.28,119.42,113.59,54.85,24.86,12.35$; HR-MS (ESI) $m / z$ : calcd for $\mathrm{C}_{21} \mathrm{H}_{20} \mathrm{NO}_{2}[\mathrm{M}+\mathrm{H}]^{+} 318.1489$, found 318.1494. Purity: $99.8 \%$ (by HPLC).

(E)-3-(3,4-dimethoxyphenyl)-2-methyl-1-(2-methylquinolin-4-yl)prop-2-en-1-o ne (24f). White solid (91 mg, 65.2\%). ${ }^{1} \mathrm{H}$ NMR (300 MHz, $\left.\mathrm{CDCl}_{3}\right) \delta 8.04-7.97(\mathrm{~m}$, 
1H), $7.70-7.59(\mathrm{~m}, 2 \mathrm{H}), 7.44-7.36(\mathrm{~m}, 1 \mathrm{H}), 7.18(\mathrm{~d}, J=7.1 \mathrm{~Hz}, 1 \mathrm{H}), 7.03(\mathrm{~d}, J=$ $1.5 \mathrm{~Hz}, 1 \mathrm{H}), 6.95(\mathrm{dd}, J=8.5,2.0 \mathrm{~Hz}, 1 \mathrm{H}), 6.79(\mathrm{dd}, J=5.3,3.2 \mathrm{~Hz}, 2 \mathrm{H}), 3.82(\mathrm{~s}$, 3H), $3.76(\mathrm{~s}, 3 \mathrm{H}), 2.70(\mathrm{~s}, 3 \mathrm{H}), 2.31(\mathrm{~s}, 3 \mathrm{H}) ;{ }^{13} \mathrm{C} \mathrm{NMR}\left(75 \mathrm{MHz}, \mathrm{CDCl}_{3}\right) \delta 198.68$, $158.25,150.30,148.75,148.08,146.94,146.46,135.66,129.94,129.02,127.97$, $126.53,125.24,124.13,123.76,119.93,113.20,110.88,55.95,25.42,12.95 ;$ HR-MS (ESI) $m / z$ : calcd for $\mathrm{C}_{22} \mathrm{H}_{12} \mathrm{NO}_{3}[\mathrm{M}+\mathrm{H}]^{+} 348.1594$, found 348.1596. Purity: $99.6 \%$ (by HPLC).

(E)-3-(3-fluoro-4-methoxyphenyl)-2-methyl-1-(2-methylquinolin-4-yl)prop-2-e n-1-one (24g). White solid (78 mg, 57.9\%). ${ }^{1} \mathrm{H}$ NMR $\left(300 \mathrm{MHz}, \mathrm{CDCl}_{3}\right) \delta 8.08(\mathrm{~d}, J$ $=8.5 \mathrm{~Hz}, 1 \mathrm{H}), 7.77-7.66(\mathrm{~m}, 2 \mathrm{H}), 7.48(\mathrm{~m}, 1 \mathrm{H}), 7.24(\mathrm{~s}, 1 \mathrm{H}), 7.19(\mathrm{dd}, J=12.4,2.2$ Hz, 1H), $7.10-7.03$ (m, 2H), 6.93 (t, $J=8.5 \mathrm{~Hz}, 1 \mathrm{H}), 3.90$ (s, 3H), 2.78 (s, 3H), 2.35 (s, 3H); ${ }^{13} \mathrm{C}$ NMR $\left(75 \mathrm{MHz}, \mathrm{CDCl}_{3}\right) \delta 198.01,157.71,147.62,145.60,144.66,136.07$, $129.42,128.63,127.71,126.81,126.04,124.60,123.17,121.85,119.42,117.15$, 116.90, 112.56, 55.73, 24.86, 12.31; HR-MS (ESI) $m / z$ : calcd for $\mathrm{C}_{21} \mathrm{H}_{19} \mathrm{FNO}_{2}$ $[\mathrm{M}+\mathrm{H}]^{+}$336.1394, found 336.1396. Purity: 95.1\% (by HPLC).

(E)-2-methyl-1-(2-methylquinolin-4-yl)-3-(4-(methylthio)phenyl)prop-2-en-1-o ne (24h). White solid (83 mg, 62.0\%). ${ }^{1} \mathrm{H}$ NMR (300 MHz, $\left.\mathrm{CDCl}_{3}\right) \delta 8.08(\mathrm{~d}, J=8.4$ $\mathrm{Hz}, 1 \mathrm{H}), 7.79-7.66(\mathrm{~m}, 2 \mathrm{H}), 7.49(\mathrm{dd}, J=11.2,4.0 \mathrm{~Hz}, 1 \mathrm{H}), 7.30-7.19(\mathrm{~m}, 5 \mathrm{H})$, $7.11(\mathrm{~s}, 1 \mathrm{H}), 2.78(\mathrm{~s}, 3 \mathrm{H}), 2.48(\mathrm{~s}, 3 \mathrm{H}), 2.36(\mathrm{~s}, 3 \mathrm{H}) ;{ }^{13} \mathrm{C} \mathrm{NMR}\left(75 \mathrm{MHz}, \mathrm{CDCl}_{3}\right) \delta$ $198.72,158.25,148.09,146.29,146.24,141.39,136.77,131.48,130.62,129.97$, $129.08,127.61,126.80,126.57,125.59,125.18,123.72,120.00,25.40,15.06,12.99$; HR-MS (ESI) $m / z$ : calcd for $\mathrm{C}_{21} \mathrm{H}_{20} \mathrm{NOS}[\mathrm{M}+\mathrm{H}]^{+} 334.1260$, found 334.1259. Purity: 
98.2\% (by HPLC).

1.8 General procedures for the preparation of $24 \mathrm{i}-\mathrm{o}$. To a solution of 16 (75 mg, $0.40 \mathrm{mmol}$ ) or 21 ( $80 \mathrm{mg}, 0.40 \mathrm{mmol})$ in $5 \mathrm{~mL} \mathrm{EtOH}$, piperidine (48 $\mu \mathrm{L}, 0.48 \mathrm{mmol})$ and indole formaldehydes $(0.48 \mathrm{mmol})$ were added. After the mixture was stirred at $95{ }^{\circ} \mathrm{C}$ for $48 \mathrm{~h}$. After reaction completed, the mixture was extracted with EtOAc $(3 \times$ $20 \mathrm{~mL}$ ), and the combined organic layers were then washed with saturated brine, dried over anhydrous $\mathrm{Na}_{2} \mathrm{SO}_{4}$, and concentrated in vacuo to afford the crude products, which was purified by column chromatography with petroleum/ethyl acetate $(2: 1)$ to give 24i-o.

(E)-3-(1H-indol-4-yl)-1-(2-methylquinolin-4-yl)prop-2-en-1-one (24i). Yellow solid (74 mg, 54.9\%). ${ }^{1} \mathrm{H}$ NMR (300 MHz, $\left.\mathrm{CDCl}_{3}\right) \delta 9.11(\mathrm{~s}, 1 \mathrm{H}), 8.11(\mathrm{dd}, J=8.2$, $4.6 \mathrm{~Hz}, 2 \mathrm{H}), 7.97(\mathrm{~d}, J=16.1 \mathrm{~Hz}, 1 \mathrm{H}), 7.78-7.66(\mathrm{~m}, 1 \mathrm{H}), 7.53(\mathrm{~d}, J=7.1 \mathrm{~Hz}, 1 \mathrm{H})$, $7.48(\mathrm{~d}, J=3.4 \mathrm{~Hz}, 1 \mathrm{H}), 7.44(\mathrm{~m}, 2 \mathrm{H}), 7.38(\mathrm{~s}, 1 \mathrm{H}), 7.35-7.27(\mathrm{~m}, 1 \mathrm{H}), 7.19(\mathrm{t}, J=$ $7.8 \mathrm{~Hz}, 1 \mathrm{H}), 6.74(\mathrm{~s}, 1 \mathrm{H}), 2.81(\mathrm{~s}, 3 \mathrm{H}) ;{ }^{13} \mathrm{C} \mathrm{NMR}\left(75 \mathrm{MHz}, \mathrm{CDCl}_{3}\right) \delta 194.81,157.99$, $150.12,147.86,145.39,137.27,129.45,128.47,127.86,126.21,125.54,125.26$, $124.82,123.19,122.63,121.49,119.49,111.40,103.12,76.96,76.54,76.12,24.83$; HR-MS (ESI) $m / z$ : calcd for $\mathrm{C}_{21} \mathrm{H}_{17} \mathrm{~N}_{2} \mathrm{O}[\mathrm{M}+\mathrm{H}]^{+} 313.1335$, found 313.1333. Purity: 97.2\% (by HPLC).

(E)-3-(1H-indol-4-yl)-2-methyl-1-(2-methylquinolin-4-yl)prop-2-en-1-one (24j). Yellow solid (69 mg, 51.1\%). ${ }^{1} \mathrm{H}$ NMR $\left(300 \mathrm{MHz}, \mathrm{CDCl}_{3}\right) \delta 8.71(\mathrm{~s}, 1 \mathrm{H}), 8.02(\mathrm{~d}, J=$ $8.4 \mathrm{~Hz}, 1 \mathrm{H}), 7.78(\mathrm{~d}, J=8.3 \mathrm{~Hz}, 1 \mathrm{H}), 7.63(\mathrm{t}, J=7.1 \mathrm{~Hz}, 1 \mathrm{H}), 7.55(\mathrm{~s}, 1 \mathrm{H}), 7.42(\mathrm{t}, J$ $=7.4 \mathrm{~Hz}, 1 \mathrm{H}), 7.29(\mathrm{~d}, J=8.0 \mathrm{~Hz}, 1 \mathrm{H}), 7.26(\mathrm{~s}, 1 \mathrm{H}), 7.22(\mathrm{~d}, J=7.3 \mathrm{~Hz}, 1 \mathrm{H}), 7.14$ 
$(\mathrm{dd}, J=13.3,5.6 \mathrm{~Hz}, 1 \mathrm{H}), 7.08-7.01(\mathrm{~m}, 1 \mathrm{H}), 5.94(\mathrm{~s}, 1 \mathrm{H}), 2.71(\mathrm{~s}, 3 \mathrm{H}), 2.31(\mathrm{~s}, 3 \mathrm{H})$;

${ }^{13} \mathrm{C}$ NMR $\left(75 \mathrm{MHz}, \mathrm{CDCl}_{3}\right) \delta 198.58,157.80,147.58,146.13,144.91,136.89,135.29$, $129.49,128.49,127.27,126.53,126.08,124.90,124.67,123.37,121.20,120.48$, 119.68, 112.13, 100.22, 24.81, 12.79; HR-MS (ESI) m/z: calcd for $\mathrm{C}_{22} \mathrm{H}_{19} \mathrm{~N}_{2} \mathrm{O}$ $[\mathrm{M}+\mathrm{H}]^{+}$327.1492, found 327.1498. Purity: 96.6\% (by HPLC).

(E)-3-(1H-indol-5-yl)-1-(2-methylquinolin-4-yl)prop-2-en-1-one (24k). Yellow solid (72 mg, 53.4\%). ${ }^{1} \mathrm{H}$ NMR (300 MHz, $\left.\mathrm{CDCl}_{3}\right) \delta 8.87(\mathrm{~s}, 1 \mathrm{H}), 8.02(\mathrm{~d}, J=8.5 \mathrm{~Hz}$, 1H), $7.96(\mathrm{~d}, J=8.4 \mathrm{~Hz}, 1 \mathrm{H}), 7.72(\mathrm{~s}, 1 \mathrm{H}), 7.66-7.56(\mathrm{~m}, 2 \mathrm{H}), 7.43(\mathrm{~d}, J=7.4 \mathrm{~Hz}$, 1H), $7.36(\mathrm{~m}, 3 \mathrm{H}), 7.18$ - $7.08(\mathrm{~m}, 2 \mathrm{H}), 6.48(\mathrm{~s}, 1 \mathrm{H}), 2.72(\mathrm{~s}, 3 \mathrm{H}) ;{ }^{13} \mathrm{C} \mathrm{NMR}(75 \mathrm{MHz}$, $\left.\mathrm{CDCl}_{3}\right) \delta 194.83,158.00,150.13,147.88,145.41,137.28,129.46,128.48,127.87$ $126.23,125.55,125.27,124.83,123.20,122.64,121.50,119.50,111.41,103.13$, 24.83; HR-MS (ESI) $m / z$ : calcd for $\mathrm{C}_{21} \mathrm{H}_{17} \mathrm{~N}_{2} \mathrm{O}[\mathrm{M}+\mathrm{H}]^{+} 313.1335$ found 313.1339 . Purity: $96.4 \%$ (by HPLC).

(E)-3-(1H-indol-5-yl)-2-methyl-1-(2-methylquinolin-4-yl)prop-2-en-1-one (24l). Yellow solid (65 mg, 49.6\%). ${ }^{1} \mathrm{H} \mathrm{NMR}\left(300 \mathrm{MHz}, \mathrm{CDCl}_{3}\right) \delta 8.98(\mathrm{~s}, 1 \mathrm{H}), 8.09$ (d, $J=$ $8.4 \mathrm{~Hz}, 1 \mathrm{H}), 7.79(\mathrm{~d}, J=8.3 \mathrm{~Hz}, 1 \mathrm{H}), 7.72(\mathrm{~s}, 1 \mathrm{H}), 7.67$ (d, $J=7.2 \mathrm{~Hz}, 1 \mathrm{H}), 7.46$ (t, $J$ $=7.2 \mathrm{~Hz}, 1 \mathrm{H}), 7.38-7.24(\mathrm{~m}, 3 \mathrm{H}), 7.19(\mathrm{~d}, J=7.6 \mathrm{~Hz}, 2 \mathrm{H}), 6.54(\mathrm{~s}, 1 \mathrm{H}), 2.78(\mathrm{~s}, 3 \mathrm{H})$, $2.45(\mathrm{~s}, 3 \mathrm{H}) ;{ }^{13} \mathrm{C} \mathrm{NMR}\left(75 \mathrm{MHz}, \mathrm{CDCl}_{3}\right) \delta 198.53,157.80,148.99,147.57,146.47$, $135.92,134.36,129.44,128.41,127.60,126.46,126.03,125.11,124.89,124.17$, 123.43, 123.37, 119.52, 110.76, 102.84, 24.81, 12.51; HR-MS (ESI) $m / z$ : calcd for $\mathrm{C}_{22} \mathrm{H}_{19} \mathrm{~N}_{2} \mathrm{O}[\mathrm{M}+\mathrm{H}]^{+}$327.1492, found 327.1497. Purity: 95.1\% (by HPLC).

(E)-2-methyl-3-(1-methyl-1H-indol-5-yl)-1-(2-methylquinolin-4-yl)prop-2-en-1- 
one (24m). Yellow solid (78 mg, 57.1\%). ${ }^{1} \mathrm{H}$ NMR (300 MHz, $\left.\mathrm{CDCl}_{3}\right) \delta 7.98(\mathrm{~d}, J=$ $8.5 \mathrm{~Hz}, 1 \mathrm{H}), 7.72-7.65(\mathrm{~m}, 1 \mathrm{H}), 7.62-7.53(\mathrm{~m}, 2 \mathrm{H}), 7.35(\mathrm{td}, J=7.0,3.5 \mathrm{~Hz}, 1 \mathrm{H})$, $7.24(\mathrm{~s}, 1 \mathrm{H}), 7.19-7.09(\mathrm{~m}, 3 \mathrm{H}), 6.93(\mathrm{~d}, J=3.1 \mathrm{~Hz}, 1 \mathrm{H}), 6.37(\mathrm{~d}, J=3.1 \mathrm{~Hz}, 1 \mathrm{H})$, $3.62(\mathrm{~s}, 3 \mathrm{H}), 2.67$ (s, 3H), $2.38-2.30(\mathrm{~s}, 3 \mathrm{H}) ;{ }^{13} \mathrm{C} \mathrm{NMR}\left(75 \mathrm{MHz}, \mathrm{CDCl}_{3}\right) \delta 198.88$, $158.25,149.37,148.12,146.89,137.11,134.75,130.19,129.83,129.05,128.55$, $126.52,126.43,125.39,124.32,124.07,123.91,119.98,109.37,102.05,32.93,25.43$, 13.06; HR-MS (ESI) $m / z$ : calcd for $\mathrm{C}_{23} \mathrm{H}_{21} \mathrm{~N}_{2} \mathrm{O}[\mathrm{M}+\mathrm{H}]^{+} 341.1648$, found 341.1654. Purity: $97.1 \%$ (by HPLC).

(E)-3-(6-methoxy-1H-indol-3-yl)-1-(2-methylquinolin-4-yl)prop-2-en-1-one

(24n). Yellow solid (65 mg, 46.9\%). ${ }^{1} \mathrm{H}$ NMR (300 MHz, DMSO-d $) \delta 8.04(\mathrm{~s}, 1 \mathrm{H})$, $8.01(\mathrm{~s}, 2 \mathrm{H}), 7.81(\mathrm{~d}, J=15.8 \mathrm{~Hz}, 1 \mathrm{H}), 7.75(\mathrm{~d}, J=7.2 \mathrm{~Hz}, 1 \mathrm{H}), 7.63-7.52(\mathrm{~m}, 2 \mathrm{H})$, $7.41(\mathrm{~d}, J=9.1 \mathrm{~Hz}, 2 \mathrm{H}), 7.18(\mathrm{~d}, J=16.0 \mathrm{~Hz}, 1 \mathrm{H}), 6.90(\mathrm{dd}, J=8.7,2.1 \mathrm{~Hz}, 1 \mathrm{H})$, $3.83(\mathrm{~s}, 3 \mathrm{H}), 2.75(\mathrm{~s}, 3 \mathrm{H}) ;{ }^{13} \mathrm{C}$ NMR (75 MHz, DMSO-d 6$) \delta 193.73,158.57,155.16$, $147.78,145.56,142.60,134.44,132.52,129.60,128.75,126.37,125.67,125.14$, $122.73,119.95,119.67,113.32,112.42,112.17,102.59,55.53,24.85$; HR-MS (ESI) $m / z$ : calcd for $\mathrm{C}_{22} \mathrm{H}_{19} \mathrm{~N}_{2} \mathrm{O}_{2}[\mathrm{M}+\mathrm{H}]^{+}$343.1441, found 343.1444. Purity: $96.0 \%$ (by HPLC).

(E)-3-(6-methoxy-1H-indol-3-yl)-2-methyl-1-(2-methylquinolin-4-yl)prop-2-en1-one (24o). Yellow solid (59 mg, 41.2\%). ${ }^{1} \mathrm{H}$ NMR (300 MHz, DMSO- $\left.d_{6}\right) \delta 11.88$ (s, 1H), $8.04(\mathrm{~d}, J=8.4 \mathrm{~Hz}, 1 \mathrm{H}), 7.88(\mathrm{~s}, 1 \mathrm{H}), 7.81-7.67(\mathrm{~m}, 2 \mathrm{H}), 7.52(\mathrm{td}, J=6.8,3.3$ $\mathrm{Hz}, 1 \mathrm{H}), 7.44(\mathrm{~d}, J=6.9 \mathrm{~Hz}, 2 \mathrm{H}), 6.99-6.90(\mathrm{~m}, 2 \mathrm{H}), 6.64(\mathrm{dd}, J=8.7,2.3 \mathrm{~Hz}, 1 \mathrm{H})$, $3.74(\mathrm{~s}, 3 \mathrm{H}), 2.74(\mathrm{~s}, 3 \mathrm{H}), 2.31(\mathrm{~s}, 3 \mathrm{H}) ;{ }^{13} \mathrm{C} \mathrm{NMR}\left(75 \mathrm{MHz}, \mathrm{DMSO}-d_{6}\right) \delta 196.21$, 
$158.25,156.37,147.41,146.46,138.33,136.59,130.38,129.65,128.77,126.23$, $125.11,123.39,121.06,119.69,118.10,118.09,111.33,110.72,94.96,55.15,40.34$, 40.06, 39.79, 39.51, 39.23, 38.95, 38.67, 24.85, 13.16; HR-MS (ESI) $\mathrm{m} / z$ : calcd for $\mathrm{C}_{23} \mathrm{H}_{21} \mathrm{~N}_{2} \mathrm{O}_{2}[\mathrm{M}+\mathrm{H}]^{+} 357.1598$, found 357.1595. Purity: $97.5 \%$ (by HPLC).

1.9 1-(2-(Hydroxymethyl)quinolin-4-yl)propan-1-one (28). To a solution of 21 (300 $\mathrm{mg}, 1.52 \mathrm{mmol})$ in $15 \mathrm{~mL}$ anhydrous $\mathrm{CH}_{2} \mathrm{Cl}_{2}$ was added $m$-CPBA (75\%, $450 \mathrm{mg}, 1.98$ mmol) in one portion. The mixture was stirred for $2 \mathrm{~h}$ at ambient temperature. Then, the reaction was quenched by $\mathrm{Na}_{2} \mathrm{~S}_{2} \mathrm{O}_{4}$ aqueous. The residue was extracted with EtOAc $(3 \times 20 \mathrm{~mL})$, and the combined organic layers were then washed with saturated $\mathrm{NaHCO}_{3}$, brine, dried over anhydrous $\mathrm{Na}_{2} \mathrm{SO}_{4}$, and concentrated in vacuo to

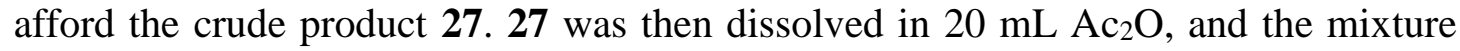
was stirred at refluxing temperature for $2 \mathrm{~h}$. After reaction completion, $\mathrm{Ac}_{2} \mathrm{O}$ was removed in vacuo, and the residue was dissolved in $5 \mathrm{~mL} \mathrm{CH}_{3} \mathrm{OH}$ followed by the addition of ammonia in $\mathrm{CH}_{3} \mathrm{OH}$. After stirring for 30 min, solvent was removed in vacuo to afford the crude produce $\mathbf{2 8}$, which was purified by column chromatography with petroleum/ethyl acetate (2:1) to give $\mathbf{2 8}$ as a yellow solid (200 mg, yield $67.9 \%$ over three steps).

1.10 General procedures for the preparation of 29a and 29c-n. The synthesis of 29a and 29c-n referred to the general procedures for the preparation of $\mathbf{2 4 c}$ and $\mathbf{2 4 d}$.

(E)-3-(3-hydroxy-4-methoxyphenyl)-1-(2-(hydroxymethyl)quinolin-4-yl)-2-met hylprop-2-en-1-one (29a). Yellow solid (61 mg, 43.7\% over two steps). ${ }^{1} \mathrm{H}$ NMR $\left(300 \mathrm{MHz}, \mathrm{CDCl}_{3}\right) \delta 8.07(\mathrm{~d}, J=8.5 \mathrm{~Hz}, 1 \mathrm{H}), 7.69(\mathrm{dd}, J=12.7,8.4 \mathrm{~Hz}, 2 \mathrm{H}), 7.51-$ 
$7.42(\mathrm{~m}, 1 \mathrm{H}), 7.20(\mathrm{~d}, J=1.5 \mathrm{~Hz}, 1 \mathrm{H}), 6.97(\mathrm{~s}, 2 \mathrm{H}), 6.75(\mathrm{~d}, J=8.7 \mathrm{~Hz}, 2 \mathrm{H}), 4.88(\mathrm{~s}$, 2H), $4.69(\mathrm{~s}, 1 \mathrm{H}), 3.83(\mathrm{~s}, 3 \mathrm{H}), 2.29(\mathrm{~s}, 3 \mathrm{H}) ;{ }^{13} \mathrm{C} \mathrm{NMR}\left(75 \mathrm{MHz}, \mathrm{CDCl}_{3}\right) \delta$ 198.49, $158.39,147.89,147.17,147.08,145.54,135.77,130.31,129.04,128.46,127.19$, $125.49,124.95,124.02,123.80,116.48,116.09,110.42,64.26,55.98,29.70 ;$ HR-MS (ESI) $m / z$ : calcd for $\mathrm{C}_{21} \mathrm{H}_{20} \mathrm{NO}_{4}[\mathrm{M}+\mathrm{H}]^{+} 350.1387$, found 350.1381 . Purity: $95.4 \%$ (by HPLC).

(E)-4-(3-(3-hydroxy-4-methoxyphenyl)-2-methylacryloyl)quinoline-2-carbalde hyde (29b). To a solution of 29a (30 mg, $0.08 \mathrm{mmol}$ ) in $2 \mathrm{~mL}$ DMSO was added IBX (29 $\mathrm{mg}, 0.10 \mathrm{mmol}$ ). The reactions were stirred for $30 \mathrm{~min}$, then the mixtures were diluted with $50 \mathrm{~mL}$ EtOAc, then washed with water $(20 \mathrm{~mL} \times 3)$, saturated brine, dried over anhydrous $\mathrm{Na}_{2} \mathrm{SO}_{4}$, and concentrated in vacuo to afford crude products, which was purified by column chromatography with petroleum/ethyl acetate $(2: 1)$ to give 29b as yellow solid (26 mg, 74.9\%). ${ }^{1} \mathrm{H}$ NMR (300 MHz, $\left.\mathrm{CDCl}_{3}\right) \delta 10.18(\mathrm{~s}, 1 \mathrm{H})$, $8.25(\mathrm{~d}, J=8.4 \mathrm{~Hz}, 1 \mathrm{H}), 7.90(\mathrm{~s}, 1 \mathrm{H}), 7.86-7.73(\mathrm{~m}, 2 \mathrm{H}), 7.62(\mathrm{dd}, J=11.2,4.1 \mathrm{~Hz}$, 1H), $6.95(\mathrm{~s}, 2 \mathrm{H}), 6.77-6.72(\mathrm{~m}, 2 \mathrm{H}), 5.71(\mathrm{~s}, 1 \mathrm{H}), 3.82(\mathrm{~s}, 3 \mathrm{H}), 2.30(\mathrm{~s}, 3 \mathrm{H}) ;{ }^{13} \mathrm{C}$ NMR (75 MHz, $\left.\mathrm{CDCl}_{3}\right) \delta 197.83,193.27,151.69,148.23,147.93,147.63,147.40$, $145.51,135.73,130.92,130.88,130.06,128.35,127.37,125.71,123.87,116.10$, 115.47, 110.40, 55.97, 29.70; HR-MS (ESI) $m / z$ : calcd for $\mathrm{C}_{21} \mathrm{H}_{18} \mathrm{NO}_{4}[\mathrm{M}+\mathrm{H}]^{+}$ 348.1230, found 348.1232. Purity: 97.8\% (by HPLC).

(E)-1-(2-chloroquinolin-4-yl)-3-(3-hydroxy-4-methoxyphenyl)-2-methylprop-2-

en-1-one (29c). White solid (65 mg, 45.9\% over two steps). ${ }^{1} \mathrm{H}$ NMR (300 MHz, $\left.\mathrm{CDCl}_{3}\right) \delta 8.01(\mathrm{~d}, J=8.4 \mathrm{~Hz}, 1 \mathrm{H}), 7.78-7.63(\mathrm{~m}, 2 \mathrm{H}), 7.48(\mathrm{t}, J=7.6 \mathrm{~Hz}, 1 \mathrm{H}), 7.28$ 
$(\mathrm{s}, 1 \mathrm{H}), 7.00(\mathrm{~s}, 2 \mathrm{H}), 6.86-6.72(\mathrm{~m}, 2 \mathrm{H}), 5.67(\mathrm{~s}, 1 \mathrm{H}), 3.84(\mathrm{~s}, 3 \mathrm{H}), 2.29(\mathrm{~s}, 3 \mathrm{H}) ;{ }^{13} \mathrm{C}$ NMR (75 MHz, $\left.\mathrm{CDCl}_{3}\right) \delta 196.88,149.93,149.39,148.15,148.00,147.59,145.54$ $135.55,131.07,129.01,128.31,127.74,125.49,124.36,124.01,120.21,116.07$, 110.42, 56.00, 29.70; HR-MS (ESI) $m / z$ : calcd for $\mathrm{C}_{20} \mathrm{H}_{17} \mathrm{ClNO}_{3}[\mathrm{M}+\mathrm{H}]^{+}$354.0891, found 327.0895. Purity: 95.8\% (by HPLC).

(E)-1-(2-(dimethylamino)quinolin-4-yl)-3-(3-hydroxy-4-methoxyphenyl)-2-met hylprop-2-en-1-one (29d). Yellow solid (82 mg, 56.6\% over two steps). ${ }^{1} \mathrm{H}$ NMR $\left(300 \mathrm{MHz}, \mathrm{DMSO}-d_{6}\right) \delta 9.16(\mathrm{~s}, 1 \mathrm{H}), 7.53(\mathrm{~d}, J=8.1 \mathrm{~Hz}, 1 \mathrm{H}), 7.49-7.36(\mathrm{~m}, 1 \mathrm{H})$, $7.32(\mathrm{~d}, J=7.9 \mathrm{~Hz}, 1 \mathrm{H}), 7.07(\mathrm{~d}, J=7.3 \mathrm{~Hz}, 1 \mathrm{H}), 7.02(\mathrm{~s}, 1 \mathrm{H}), 6.96(\mathrm{~s}, 1 \mathrm{H}), 6.90(\mathrm{~s}$, 1H), $6.82(\mathrm{dd}, J=16.2,8.1 \mathrm{~Hz}, 2 \mathrm{H}), 3.69(\mathrm{~s}, 3 \mathrm{H}), 3.08(\mathrm{~s}, 6 \mathrm{H}), 2.17(\mathrm{~s}, 3 \mathrm{H}) ;{ }^{13} \mathrm{C} \mathrm{NMR}$ $\left(75 \mathrm{MHz}, \mathrm{DMSO}-d_{6}\right) \delta 198.74,156.79,149.64,148.20,147.51,146.81,146.47$, $134.80,130.14,128.04,126.84,125.25,123.62,122.32,119.77,117.40,112.34$ 107.92, 56.01, 38.13, 13.07; HR-MS (ESI) m/z: calcd for $\mathrm{C}_{22} \mathrm{H}_{23} \mathrm{~N}_{2} \mathrm{O}_{3}[\mathrm{M}+\mathrm{H}]^{+}$ 363.1703, found 363.1706. Purity: 96.4\% (by HPLC).

(E)-3-(3-hydroxy-4-methoxyphenyl)-2-methyl-1-(2-(pyrrolidin-1-yl)quinolin-4yl)prop-2-en-1-one (29e). Yellow solid (88 mg, 56.6\% over two steps). ${ }^{1} \mathrm{H}$ NMR $\left(300 \mathrm{MHz}, \mathrm{CDCl}_{3}\right) \delta 7.76(\mathrm{~d}, J=8.5 \mathrm{~Hz}, 1 \mathrm{H}), 7.61-7.49(\mathrm{~m}, 2 \mathrm{H}), 7.18(\mathrm{~s}, 1 \mathrm{H}), 7.16-$ $7.07(\mathrm{~m}, 1 \mathrm{H}), 7.05(\mathrm{~s}, 1 \mathrm{H}), 6.85(\mathrm{q}, J=8.2 \mathrm{~Hz}, 2 \mathrm{H}), 6.66(\mathrm{~s}, 1 \mathrm{H}), 3.89(\mathrm{~s}, 3 \mathrm{H}), 3.62(\mathrm{~s}$, 4H), $2.32(\mathrm{~s}, 3 \mathrm{H}), 2.03(\mathrm{~s}, 4 \mathrm{H}) ;{ }^{13} \mathrm{C} \mathrm{NMR}\left(75 \mathrm{MHz}, \mathrm{CDCl}_{3}\right) \delta 199.38,154.69,148.62$, $147.99,147.51,146.68,145.65,135.59,129.97,128.67,126.23,125.28,123.65$, $121.95,119.99,116.25,110.52,108.61,55.94,47.00,25.53,12.79$; HR-MS (ESI) $m / z:$ calcd for $\mathrm{C}_{24} \mathrm{H}_{25} \mathrm{~N}_{2} \mathrm{O}_{3}[\mathrm{M}+\mathrm{H}]^{+} 389.1860$, found 389.1868. Purity: 99.4\% (by HPLC). 
(E)-3-(3-hydroxy-4-methoxyphenyl)-2-methyl-1-(2-morpholinoquinolin-4-yl)pr op-2-en-1-one (29f). Yellow solid (98 mg, 60.6\% over two steps). ${ }^{1} \mathrm{H}$ NMR (300 $\left.\mathrm{MHz}, \mathrm{CDCl}_{3}\right) \delta 7.76(\mathrm{~d}, J=8.3 \mathrm{~Hz}, 1 \mathrm{H}), 7.59-7.53(\mathrm{~m}, 2 \mathrm{H}), 7.22(\mathrm{t}, J=7.5 \mathrm{~Hz}, 1 \mathrm{H})$, $7.13(\mathrm{~s}, 1 \mathrm{H}), 7.05(\mathrm{~s}, 1 \mathrm{H}), 6.90(\mathrm{~s}, 1 \mathrm{H}), 6.89-6.80(\mathrm{~m}, 2 \mathrm{H}), 5.68(\mathrm{~s}, 1 \mathrm{H}), 3.91(\mathrm{~s}, 3 \mathrm{H})$, $3.85(\mathrm{~d}, J=5.1 \mathrm{~Hz}, 4 \mathrm{H}), 3.73(\mathrm{~d}, J=5.1 \mathrm{~Hz}, 4 \mathrm{H}), 2.34(\mathrm{~s}, 3 \mathrm{H}) ;{ }^{13} \mathrm{C} \mathrm{NMR}(75 \mathrm{MHz}$, $\left.\mathrm{CDCl}_{3}\right) \delta 199.17,156.49,148.11,147.97,147.78,146.78,145.49,135.67,130.12$ $128.65,127.11,125.14,123.75,123.29,120.70,116.08,110.42,107.50,66.82,55.97$ 45.48, 12.83; HR-MS (ESI) $m / z$ : calcd for $\mathrm{C}_{24} \mathrm{H}_{25} \mathrm{~N}_{2} \mathrm{O}_{4}[\mathrm{M}+\mathrm{H}]^{+} 405.1809$, found 405.1810. Purity: $96.5 \%$ (by HPLC).

(E)-3-(3-hydroxy-4-methoxyphenyl)-2-methyl-1-(2-(methylamino)quinolin-4-yl )prop-2-en-1-one (29g). Yellow solid (56 mg, 40.2\% over two steps). ${ }^{1} \mathrm{H}$ NMR (300 $\left.\mathrm{MHz}, \mathrm{CDCl}_{3}\right) \delta 7.75(\mathrm{dt}, J=8.2,1.3 \mathrm{~Hz}, 1 \mathrm{H}), 7.53(\mathrm{dd}, J=8.9,7.6 \mathrm{~Hz}, 2 \mathrm{H}), 7.21-$ $7.13(\mathrm{~m}, 2 \mathrm{H}), 7.04(\mathrm{~d}, J=2.0 \mathrm{~Hz}, 1 \mathrm{H}), 6.92-6.81(\mathrm{~m}, 2 \mathrm{H}), 6.59(\mathrm{~s}, 1 \mathrm{H}), 5.35(\mathrm{~s}, 1 \mathrm{H})$, $3.89(\mathrm{~s}, 3 \mathrm{H}), 3.06(\mathrm{~s}, 3 \mathrm{H}), 2.31(\mathrm{~s}, 3 \mathrm{H}) ;{ }^{13} \mathrm{C} \mathrm{NMR}\left(75 \mathrm{MHz}, \mathrm{CDCl}_{3}\right) \delta 198.80,156.52$, $148.06,147.65,146.83,145.66,135.48,130.24,128.57,125.88,125.35,123.67$, $122.72,120.65,116.29,110.54,109.13,55.95,28.79,12.78 ;$ HR-MS (ESI) $m / z:$ calcd for $\mathrm{C}_{21} \mathrm{H}_{21} \mathrm{~N}_{2} \mathrm{O}_{3}[\mathrm{M}+\mathrm{H}]^{+}$349.1547, found 327.1555. Purity: 96.0\% (by HPLC).

(E)-1-(2-(ethylamino)quinolin-4-yl)-3-(3-hydroxy-4-methoxyphenyl)-2-methylp rop-2-en-1-one (29h). Yellow solid (63 mg, 43.5\% over two steps). ${ }^{1} \mathrm{H}$ NMR (300 $\left.\mathrm{MHz}, \mathrm{CDCl}_{3}\right) \delta 7.72(\mathrm{~d}, J=8.5 \mathrm{~Hz}, 1 \mathrm{H}), 7.64-7.49(\mathrm{~m}, 2 \mathrm{H}), 7.18-7.14(\mathrm{~m}, 2 \mathrm{H})$, $7.04(\mathrm{~d}, J=1.8 \mathrm{~Hz}, 1 \mathrm{H}), 6.90(\mathrm{dd}, J=8.5,1.7 \mathrm{~Hz}, 1 \mathrm{H}), 6.84(\mathrm{~d}, J=8.4 \mathrm{~Hz}, 1 \mathrm{H}), 6.58$ $(\mathrm{s}, 1 \mathrm{H}), 4.90(\mathrm{~s}, 1 \mathrm{H}), 3.89(\mathrm{~s}, 3 \mathrm{H}), 3.60-3.48(\mathrm{~m}, 2 \mathrm{H}), 2.31(\mathrm{~s}, 3 \mathrm{H}), 1.27(\mathrm{~m}, 3 \mathrm{H}) ;{ }^{13} \mathrm{C}$ 
NMR $\left(75 \mathrm{MHz}, \mathrm{CDCl}_{3}\right) \delta 198.94,155.95,148.10,147.90,146.74,145.68,135.52$, $130.12,128.61,126.19,125.32,123.63,122.62,120.77,116.34,110.57,109.21$, 55.95, 36.67, 29.70, 14.95; HR-MS (ESI) $m / z$ : calcd for $\mathrm{C}_{22} \mathrm{H}_{23} \mathrm{~N}_{2} \mathrm{O}_{3}[\mathrm{M}+\mathrm{H}]^{+}$ 363.1703, found 363.1702. Purity: 96.8\% (by HPLC).

(E)-1-(2-(cyclopropylamino)quinolin-4-yl)-3-(3-hydroxy-4-methoxyphenyl)-2-

methylprop-2-en-1-one (29i). Yellow solid (55 mg, 36.7\% over two steps). ${ }^{1} \mathrm{H}$ NMR $\left(300 \mathrm{MHz}, \mathrm{CDCl}_{3}\right) \delta 7.62(\mathrm{~d}, J=8.5 \mathrm{~Hz}, 1 \mathrm{H}), 7.49-7.43(\mathrm{~m}, 2 \mathrm{H}), 7.19-7.12(\mathrm{~m}$, 1H), $7.10(\mathrm{~s}, 1 \mathrm{H}), 6.95(\mathrm{~s}, 2 \mathrm{H}), 6.90-6.83(\mathrm{~m}, 1 \mathrm{H}), 6.79(\mathrm{~d}, J=8.5 \mathrm{~Hz}, 1 \mathrm{H}), 5.47(\mathrm{~s}$, 1H), $3.84(\mathrm{~s}, 3 \mathrm{H}), 2.62$ - $2.49(\mathrm{~m}, 1 \mathrm{H}), 2.28(\mathrm{~s}, 3 \mathrm{H}), 1.18(\mathrm{~s}, 4 \mathrm{H}) ;{ }^{13} \mathrm{C} \mathrm{NMR}(75 \mathrm{MHz}$, $\left.\mathrm{CDCl}_{3}\right) \delta 198.98,176.06,157.43,147.79,146.86,145.75,135.56,130.27,128.62$ $125.99,125.40,123.51,122.95,121.10,116.45,115.52,110.60,107.84,55.96,29.70$, 24.01, 12.82; HR-MS (ESI) m/z: calcd for $\mathrm{C}_{23} \mathrm{H}_{23} \mathrm{~N}_{2} \mathrm{O}_{3}[\mathrm{M}+\mathrm{H}]^{+} 375.1703$, found 327.1709. Purity: $96.4 \%$ (by HPLC).

(E)-3-(3-hydroxy-4-methoxyphenyl)-1-(2-((4-methoxybenzyl)amino)quinolin-4yl)-2-methylprop-2-en-1-one (29j). Yellow solid (103 mg, 56.7\% over two steps). ${ }^{1} \mathrm{H}$ NMR (300 MHz, $\left.\mathrm{CDCl}_{3}\right) \delta 7.68(\mathrm{~d}, J=8.4 \mathrm{~Hz}, 1 \mathrm{H}), 7.51-7.40(\mathrm{~m}, 2 \mathrm{H}), 7.23-7.18$ (s, 2H), $7.10(\mathrm{dd}, J=11.3,3.8 \mathrm{~Hz}, 1 \mathrm{H}), 7.05(\mathrm{~s}, 1 \mathrm{H}), 6.93(\mathrm{~s}, 1 \mathrm{H}), 6.77$ - $6.74(\mathrm{~m}, 4 \mathrm{H})$, $6.49(\mathrm{~s}, 1 \mathrm{H}), 5.14(\mathrm{~s}, 1 \mathrm{H}), 4.54(\mathrm{~s}, 2 \mathrm{H}), 3.79(\mathrm{~s}, 3 \mathrm{H}), 3.68(\mathrm{~s}, 3 \mathrm{H}), 2.20(\mathrm{~s}, 3 \mathrm{H}) ;{ }^{13} \mathrm{C}$ NMR (75 MHz, $\left.\mathrm{CDCl}_{3}\right) \delta 198.83,158.93,155.68,148.14,147.94,147.77,146.70$, $145.57,135.53,130.93,130.12,129.09,128.61,126.47,125.32,123.71,122.81$, 120.96, 116.24, 114.09, 110.50, 109.59, 55.94, 55.29, 45.40, 29.71; HR-MS (ESI) $m / z:$ calcd for $\mathrm{C}_{28} \mathrm{H}_{27} \mathrm{~N}_{2} \mathrm{O}_{4}[\mathrm{M}+\mathrm{H}]^{+} 455.1965$, found 455.1969. Purity: 95.8\% (by HPLC). 
(E)-3-(3-hydroxy-4-methoxyphenyl)-1-(2-methoxyquinolin-4-yl)-2-methylprop-

2-en-1-one (29k). Yellow solid (88 mg, 63.0\% over two steps). ${ }^{1} \mathrm{H}$ NMR (300 MHz, $\left.\mathrm{CDCl}_{3}\right) \delta 7.90(\mathrm{~d}, J=8.4 \mathrm{~Hz}, 1 \mathrm{H}), 7.68-7.62(\mathrm{~m}, 2 \mathrm{H}), 7.42-7.31(\mathrm{~m}, 1 \mathrm{H}), 7.14(\mathrm{~s}$, 1H), $7.05(\mathrm{~d}, J=1.8 \mathrm{~Hz}, 1 \mathrm{H}), 6.91-6.77(\mathrm{~m}, 3 \mathrm{H}), 5.62(\mathrm{~s}, 1 \mathrm{H}), 4.11(\mathrm{~s}, 3 \mathrm{H}), 3.91(\mathrm{~s}$, 3H), $2.34(\mathrm{~s}, 3 \mathrm{H}) ;{ }^{13} \mathrm{C} \mathrm{NMR}\left(75 \mathrm{MHz}, \mathrm{CDCl}_{3}\right) \delta 198.27,161.47,148.94,147.76$, $146.93,146.85,145.45,135.63,130.00,128.58,127.63,125.35,124.67,123.76$, 122.59, 116.09, 111.41, 110.38, 55.95, 53.64, 12.83; HR-MS (ESI) $m / z$ : calcd for $\mathrm{C}_{21} \mathrm{H}_{20} \mathrm{NO}_{4}[\mathrm{M}+\mathrm{H}]^{+} 350.1387$, found 350.1392. Purity: 96.0\% (by HPLC).

(E)-3-(3-hydroxy-4-methoxyphenyl)-2-methyl-1-(quinolin-4-yl)prop-2-en-1-one (29l). White solid (92 mg, $72.0 \%$ over two steps). ${ }^{1} \mathrm{H}$ NMR (300 $\left.\mathrm{MHz}, \mathrm{CDCl}_{3}\right) \delta 8.88$ (d, $J=4.3 \mathrm{~Hz}, 1 \mathrm{H}), 8.11(\mathrm{~d}, J=8.5 \mathrm{~Hz}, 1 \mathrm{H}), 7.73(\mathrm{~d}, J=8.0 \mathrm{~Hz}, 1 \mathrm{H}), 7.66$ (dd, $J=$ 11.2, 4.1 Hz, 1H), $7.47(\mathrm{dd}, J=11.2,4.0 \mathrm{~Hz}, 1 \mathrm{H}), 7.28(\mathrm{~d}, J=4.3 \mathrm{~Hz}, 1 \mathrm{H}), 7.00-6.90$ (m, 2H), 6.82 - $6.74(\mathrm{~m}, 2 \mathrm{H}), 3.80(\mathrm{~s}, 3 \mathrm{H}), 2.28(\mathrm{~s}, 3 \mathrm{H}) ;{ }^{13} \mathrm{C} \mathrm{NMR}\left(75 \mathrm{MHz}, \mathrm{CDCl}_{3}\right) \delta$ $198.44,149.27,148.30,148.14,147.22,146.51,145.86,135.69,130.09,129.57$ 128.40, 127.57, 125.53, 123.62, 119.20, 116.43, 110.61, 55.94, 29.70; HR-MS (ESI) $m / z$ : calcd for $\mathrm{C}_{20} \mathrm{H}_{18} \mathrm{NO}_{3}[\mathrm{M}+\mathrm{H}]^{+}$320.1281, found 320.1286. Purity: $98.2 \%$ (by HPLC).

(E)-4-(3-(3-hydroxy-4-methoxyphenyl)-2-methylacryloyl)quinolin-2(1H)-one (29m). Yellow solid (72 mg, 53.7\% over two steps). ${ }^{1} \mathrm{H}$ NMR (300 MHz, $\left.\mathrm{CDCl}_{3}\right) \delta$ $12.71(\mathrm{~s}, 1 \mathrm{H}), 7.44(\mathrm{~s}, 2 \mathrm{H}), 7.39(\mathrm{~d}, J=8.2 \mathrm{~Hz}, 1 \mathrm{H}), 7.23(\mathrm{~s}, 1 \mathrm{H}), 7.12(\mathrm{~s}, 1 \mathrm{H}), 7.02(\mathrm{~s}$, 1H), $6.84(\mathrm{~d}, J=7.8 \mathrm{~Hz}, 1 \mathrm{H}), 6.76(\mathrm{~d}, J=8.1 \mathrm{~Hz}, 1 \mathrm{H}), 6.62(\mathrm{~s}, 1 \mathrm{H}), 6.13(\mathrm{~s}, 1 \mathrm{H}), 3.81$ (s, 3H), 2.24 (s, 3H); ${ }^{13} \mathrm{C}$ NMR (75 MHz, $\left.\mathrm{CDCl}_{3}\right) \delta 197.04,163.73,151.34,148.13$, 
$147.27,145.59,138.70,134.95,131.36,128.37,126.12,124.05,123.28,119.17$, 118.02, 116.77, 116.31, 110.52, 55.97, 29.70; HR-MS (ESI) $\mathrm{m} / z$ : calcd for $\mathrm{C}_{20} \mathrm{H}_{18} \mathrm{NO}_{4}[\mathrm{M}+\mathrm{H}]^{+} 336.1230$, found 336.1233. Purity: 92.5\% (by HPLC).

\section{Ethyl(E)-4-(3-(3-hydroxy-4-methoxyphenyl)-2-methylacryloyl)quinoline-2-car}

boxylate(29n). Yellow solid (82 mg, 52.4\% over two steps). ${ }^{1} \mathrm{H}$ NMR (300 MHz, $\left.\mathrm{CDCl}_{3}\right) \delta 8.26(\mathrm{~d}, J=8.5 \mathrm{~Hz}, 1 \mathrm{H}), 8.04(\mathrm{~s}, 1 \mathrm{H}), 7.73-7.64(\mathrm{~m}, 2 \mathrm{H}), 7.54(\mathrm{t}, J=8.1$ Hz, 1H), $7.03-6.87(\mathrm{~m}, 2 \mathrm{H}), 6.82-6.66(\mathrm{~m}, 2 \mathrm{H}), 4.44(\mathrm{q}, J=7.1 \mathrm{~Hz}, 2 \mathrm{H}), 3.75(\mathrm{~s}$, 3H), $2.27(\mathrm{~s}, 3 \mathrm{H}), 1.36(\mathrm{t}, J=7.1 \mathrm{~Hz}, 3 \mathrm{H}) ;{ }^{13} \mathrm{C} \mathrm{NMR}\left(75 \mathrm{MHz}, \mathrm{CDCl}_{3}\right) \delta 197.89$, $164.90,148.16,147.78,147.61,147.56,147.38,145.62,135.55,130.98,130.67$ $129.42,128.28,126.50,125.28,123.89,119.03,116.28,110.50,62.46,55.90,29.67$, 14.30; HR-MS (ESI) $m / z$ : calcd for $\mathrm{C}_{23} \mathrm{H}_{22} \mathrm{NO}_{5}[\mathrm{M}+\mathrm{H}]^{+} 392.1492$, found 392.1493. Purity: 95.1\% (by HPLC).

1.11 2-Chloroquinoline-4-carbaldehyde (34). Intermediate 33 was synthesized according to literature report ${ }^{[40]} . \mathbf{3 4}$ was then prepared as the same procedures of $\mathbf{1 9}$ with $33(5.0 \mathrm{~g}, 25.8 \mathrm{mmol})$ and Dess-Martin oxidant $(12.1 \mathrm{~g}, 28.4 \mathrm{mmol})$ as the reagents. White solid, 84.0\%. ${ }^{1} \mathrm{H}$ NMR $\left(300 \mathrm{MHz}, \mathrm{CDCl}_{3}\right) \delta 10.46(\mathrm{~s}, 1 \mathrm{H}), 8.94$ (dd, $J$ $=8.5,1.5 \mathrm{~Hz}, 1 \mathrm{H}), 8.15-8.07(\mathrm{~m}, 1 \mathrm{H}), 7.87-7.70(\mathrm{~m}, 3 \mathrm{H}) ;{ }^{13} \mathrm{C} \mathrm{NMR}(75 \mathrm{MHz}$, $\left.\mathrm{CDCl}_{3}\right) \delta 191.10,150.68,149.20,139.51,131.30,129.45,129.10,127.28,124.49$, 122.79; ESI-MS $m / z[\mathrm{M}+\mathrm{Na}]^{+} 214.0$.

1.12 1-(2-Chloroquinolin-4-yl)propan-1-ol (35). 35 was prepared as the same procedures of 20. Colorless oil, yield 72.9\%. ${ }^{1} \mathrm{H}$ NMR $\left(300 \mathrm{MHz}, \mathrm{CDCl}_{3}\right) \delta 8.00-$ $7.93(\mathrm{~m}, 1 \mathrm{H}), 7.93-7.86(\mathrm{~m}, 1 \mathrm{H}), 7.71-7.62(\mathrm{~m}, 1 \mathrm{H}), 7.53(\mathrm{~s}, 1 \mathrm{H}), 7.52-7.44(\mathrm{~m}$, 
1H), 5.35 (dd, $J=7.7,4.2 \mathrm{~Hz}, 1 \mathrm{H}), 3.05(\mathrm{~s}, 1 \mathrm{H}), 1.99-1.76(\mathrm{~m}, 2 \mathrm{H}), 1.04(\mathrm{t}, J=7.4$ $\mathrm{Hz}, 3 \mathrm{H}) ;{ }^{13} \mathrm{C} \mathrm{NMR}\left(75 \mathrm{MHz}, \mathrm{CDCl}_{3}\right) \delta 153.88,151.00,147.89,130.10,129.13$, $126.72,124.24,123.10,118.83,70.97,31.19,10.11 ;$ ESI-MS $m / z[\mathrm{M}+\mathrm{Na}]^{+} 244.1$.

1.13 1-(2-Chloroquinolin-4-yl)propan-1-one (36). 36 was prepared as the same procedures of 21. Yellow solid, yield 65.0\%. ${ }^{1} \mathrm{H}$ NMR (300 MHz, $\left.\mathrm{CDCl}_{3}\right) \delta 8.19(\mathrm{~d}, \mathrm{~J}$ $=8.2 \mathrm{~Hz}, 1 \mathrm{H}), 8.05(\mathrm{~d}, J=8.5 \mathrm{~Hz}, 1 \mathrm{H}), 7.81-7.72(\mathrm{~m}, 1 \mathrm{H}), 7.64-7.56(\mathrm{~m}, 1 \mathrm{H}), 7.51$ $(\mathrm{s}, 1 \mathrm{H}), 3.02(\mathrm{q}, J=7.2 \mathrm{~Hz}, 2 \mathrm{H}), 1.28(\mathrm{t}, J=7.2 \mathrm{~Hz}, 3 \mathrm{H}) ;{ }^{13} \mathrm{C} \mathrm{NMR}\left(75 \mathrm{MHz}, \mathrm{CDCl}_{3}\right)$ $\delta 203.03,150.07,148.79,146.79,130.99,129.05,128.25,125.36,122.71,120.24$, 35.93, 7.88; ESI-MS $m / z,[\mathrm{M}+\mathrm{Na}]^{+} 242.0$.

1.14 General procedures for the preparation of $\mathbf{3 7 a}-\mathbf{a}$. To a solution of $\mathbf{3 6}$ (150 mg, $0.68 \mathrm{mml})$ in $2 \mathrm{~mL}$ EtOH in sealed tube was added secondary amines $(3.4 \mathrm{mmol})$. The mixture was stirred at $80{ }^{\circ} \mathrm{C}$ for $6 \mathrm{~h}$. Then, the mixture was concentrated in vacuo to afford the crude products, which was purified by column chromatography with petroleum/ethyl acetate $(2: 1)$ to give $\mathbf{3 7 a - c}$ as yellow solids.

1-(2-(Dimethylamino)quinolin-4-yl)propan-1-one (37a). Yellow solid (135 mg, 86.5\%). ${ }^{1} \mathrm{HNMR}\left(300 \mathrm{MHz}, \mathrm{CDCl}_{3}\right) \delta 7.88(\mathrm{~d}, J=8.3 \mathrm{~Hz}, 1 \mathrm{H}), 7.74(\mathrm{~d}, J=8.5 \mathrm{~Hz}$, 1H), $7.58-7.50(\mathrm{~m}, 1 \mathrm{H}), 7.26-7.18(\mathrm{~m}, 1 \mathrm{H}), 6.95(\mathrm{~s}, 1 \mathrm{H}), 3.23(\mathrm{~s}, 6 \mathrm{H}), 2.99$ (q, $J=$ $7.2 \mathrm{~Hz}, 2 \mathrm{H}), 1.27(\mathrm{~s}, 3 \mathrm{H}) ;{ }^{13} \mathrm{C} \mathrm{NMR}\left(75 \mathrm{MHz}, \mathrm{CDCl}_{3}\right) \delta 205.53,156.66,148.97$, 146.30, 129.84, 126.93, 124.76, 122.63, 118.06, 106.85, 38.02, 36.08, 29.69; ESI-MS $m / z[\mathrm{M}+\mathrm{Na}]^{+} 251.1$

1-(2-(Pyrrolidin-1-yl)quinolin-4-yl)propan-1-one (37b). Yellow solid (142 mg, 81.8\%). ${ }^{1} \mathrm{H}$ NMR (300 MHz, $\left.\mathrm{CDCl}_{3}\right) \delta 7.91-7.84(\mathrm{~m}, 1 \mathrm{H}), 7.74(\mathrm{~d}, J=8.4 \mathrm{~Hz}, 1 \mathrm{H})$, 
$7.58-7.50(\mathrm{~m}, 1 \mathrm{H}), 7.20(\mathrm{~d}, J=7.7 \mathrm{~Hz}, 1 \mathrm{H}), 6.78(\mathrm{~s}, 1 \mathrm{H}), 3.62(\mathrm{~s}, 4 \mathrm{H}), 2.99(\mathrm{q}, J=$

$7.2 \mathrm{~Hz}, 2 \mathrm{H}), 2.05(\mathrm{~s}, 4 \mathrm{H}), 1.27(\mathrm{~s}, 3 \mathrm{H}) ;{ }^{13} \mathrm{C} \mathrm{NMR}\left(75 \mathrm{MHz}, \mathrm{CDCl}_{3}\right) \delta 205.52,154.79$, $149.36,146.05,129.81,126.73,124.88,122.26,118.20,108.08,46.89,36.09,25.51$, 8.10; ESI-MS $m / z[\mathrm{M}+\mathrm{Na}]^{+} 277.1$.

1-(2-Morpholinoquinolin-4-yl)propan-1-one (37c). Yellow solid (164 mg, 88.8\%). ${ }^{1} \mathrm{H}$ NMR (300 MHz, $\left.\mathrm{CDCl}_{3}\right) \delta 7.95-7.84(\mathrm{~m}, 1 \mathrm{H}), 7.75(\mathrm{~d}, J=8.4 \mathrm{~Hz}, 1 \mathrm{H})$, $7.64-7.53(\mathrm{~m}, 1 \mathrm{H}), 7.33-7.24(\mathrm{~m}, 1 \mathrm{H}), 7.03(\mathrm{~s}, 1 \mathrm{H}), 3.86(\mathrm{t}, J=4.8 \mathrm{~Hz}, 4 \mathrm{H}), 3.72(\mathrm{t}$, $J=4.8 \mathrm{~Hz}, 4 \mathrm{H}), 2.99(\mathrm{q}, J=7.2 \mathrm{~Hz}, 2 \mathrm{H}), 1.28(\mathrm{t}, J=7.3 \mathrm{~Hz}, 3 \mathrm{H}) ;{ }^{13} \mathrm{C} \mathrm{NMR}(75 \mathrm{MHz}$, $\left.\mathrm{CDCl}_{3}\right) \delta 205.28,156.59,148.55,146.72,130.06,127.31,124.79,123.70,118.96$, 107.15, 66.77, 45.59, 36.11, 8.06; ESI-MS m/z [M+Na] ${ }^{+} 293.1$.

1.15 General procedures for the preparation of 39a-d. To a solution of $\mathbf{3 5}$ (100 mg, $0.45 \mathrm{mmol})$ in $2 \mathrm{~mL} \mathrm{EtOH}$ in sealed tube was added primary amines $(4.5 \mathrm{mmol})$. The mixture was stirred at $150{ }^{\circ} \mathrm{C}$ for $2 \mathrm{~d}$. Then, the mixture was concentrated in vacuo to afford the crude products 38a-d. 38a-d were dissolved in $5 \mathrm{~mL}$ DMSO, IBX (150 mg, $0.56 \mathrm{mmol}$ ) was added. The reactions were stirred for $30 \mathrm{~min}$, then the mixtures were diluted with $50 \mathrm{~mL}$ EtOAc, then washed with water $(20 \mathrm{~mL} \times 3)$, saturated brine, dried over anhydrous $\mathrm{Na}_{2} \mathrm{SO}_{4}$, and concentrated in vacuo to afford crude products, which was purified by column chromatography with petroleum/ethyl acetate (2:1) to give 39a-d.

1-(2-(Methylamino)quinolin-4-yl)propan-1-one (39a). Colorless oil (55 mg, 56.9\%). ${ }^{1} \mathrm{H}$ NMR (300 MHz, $\left.\mathrm{CDCl}_{3}\right) \delta 7.96-7.86(\mathrm{~m}, 1 \mathrm{H}), 7.74(\mathrm{~d}, J=8.4 \mathrm{~Hz}, 1 \mathrm{H})$, $7.56(\mathrm{~m}, 1 \mathrm{H}), 7.30-7.19(\mathrm{~m}, 1 \mathrm{H}), 6.71(\mathrm{~s}, 1 \mathrm{H}), 5.00(\mathrm{~s}, 1 \mathrm{H}), 3.09(\mathrm{~d}, J=4.4 \mathrm{~Hz}, 3 \mathrm{H})$ 
$2.94(\mathrm{q}, J=7.3 \mathrm{~Hz}, 2 \mathrm{H}), 1.25(\mathrm{t}, J=7.2 \mathrm{~Hz}, 3 \mathrm{H}) ;{ }^{13} \mathrm{C} \mathrm{NMR}\left(75 \mathrm{MHz}, \mathrm{CDCl}_{3}\right) \delta$ 205.02, 156.61, 148.84, 146.08, 130.00, 126.64, 125.00, 123.00, 119.01, 109.49, 35.92, 28.65, 8.03; ESI-MS $m / z[\mathrm{M}+\mathrm{Na}]^{+} 237.1$.

1-(2-(Ethylamino)quinolin-4-yl)propan-1-one (39b). Colorless oil (51 mg, 49.1\%). ${ }^{1} \mathrm{H}$ NMR (300 MHz, $\left.\mathrm{CDCl}_{3}\right) \delta 7.90(\mathrm{~d}, J=8.2 \mathrm{~Hz}, 1 \mathrm{H}), 7.71(\mathrm{~d}, J=8.4 \mathrm{~Hz}$, 1H), $7.55(\mathrm{t}, J=7.7 \mathrm{~Hz}, 1 \mathrm{H}), 7.25(\mathrm{~d}, J=8.5 \mathrm{~Hz}, 1 \mathrm{H}), 6.71(\mathrm{~s}, 1 \mathrm{H}), 4.80(\mathrm{~s}, 1 \mathrm{H}), 3.56$ $(\mathrm{d}, J=6.6 \mathrm{~Hz}, 2 \mathrm{H}), 2.95(\mathrm{~d}, J=7.3 \mathrm{~Hz}, 2 \mathrm{H}), 1.36-1.19(\mathrm{~m}, 6 \mathrm{H}) ;{ }^{13} \mathrm{C} \mathrm{NMR}(75 \mathrm{MHz}$, $\left.\mathrm{CDCl}_{3}\right) \delta 205.05,155.97,148.99,146.05,129.94,126.73,124.97,122.94,119.05$, 109.52, 36.55, 35.91, 14.93, 8.05; ESI-MS $m / z[\mathrm{M}+\mathrm{Na}]^{+} 253.1$.

1-(2-((4-Methoxybenzyl)amino)quinolin-4-yl)propan-1-one (39d). Colorless oil (65 mg, 45.0\%). ${ }^{1} \mathrm{H}$ NMR (300 MHz, $\left.\mathrm{CDCl}_{3}\right) \delta 7.95-7.88(\mathrm{~m}, 1 \mathrm{H}), 7.74(\mathrm{~d}, J=8.4$ $\mathrm{Hz}, 1 \mathrm{H}), 7.60-7.50(\mathrm{~m}, 1 \mathrm{H}), 7.30(\mathrm{~d}, J=8.2 \mathrm{~Hz}, 2 \mathrm{H}), 7.26-7.20(\mathrm{~m}, 1 \mathrm{H}), 6.89-$ $6.82(\mathrm{~m}, 2 \mathrm{H}), 6.68(\mathrm{~s}, 1 \mathrm{H}), 5.12(\mathrm{~d}, J=5.6 \mathrm{~Hz}, 1 \mathrm{H}), 4.64(\mathrm{~d}, J=5.4 \mathrm{~Hz}, 2 \mathrm{H}), 3.77(\mathrm{~s}$, 3H), $2.87(\mathrm{~d}, J=7.2 \mathrm{~Hz}, 2 \mathrm{H}), 1.24-1.13(\mathrm{~m}, 3 \mathrm{H}) ;{ }^{13} \mathrm{C} \mathrm{NMR}\left(75 \mathrm{MHz}, \mathrm{CDCl}_{3}\right) \delta$ $204.95,158.98,155.69,148.89,145.89,131.08,130.00,129.19,126.86,125.04$, 123.16, 119.24, 114.07, 109.99, 55.30, 45.29, 35.83, 8.06; ESI-MS $m / z[\mathrm{M}+\mathrm{Na}]^{+}$ 343.2 .

1.16 4-Propionylquinoline-2-carbonitrile (40). To a solution of $\mathbf{3 6}$ (500 mg, 2.25 mmol) in $10 \mathrm{~mL}$ DMF was added $\mathrm{Ph}_{3}\left(\mathrm{PPh}_{3}\right)_{4}(260 \mathrm{mg}, 0.25 \mathrm{mmol}), \mathrm{Zn}(\mathrm{CN})_{2}(320 \mathrm{mg}$, $2.7 \mathrm{mmol}$ ), the mixture was stirred at $120^{\circ} \mathrm{C}$ for $2 \mathrm{~h}$ under nitrogen atmosphere. Then, the mixture was diluted with $50 \mathrm{~mL}$ EtOAc, washed with water $(20 \mathrm{~mL} \times 3)$, saturated brine, dried over anhydrous $\mathrm{Na}_{2} \mathrm{SO}_{4}$, and concentrated in vacuo to afford crude 
products, which was purified by column chromatography with petroleum/ethyl acetate (30:1) to give 40 as a yellow solid (415 mg, 87.0\%). ${ }^{1} \mathrm{H}$ NMR (300 $\left.\mathrm{MHz}, \mathrm{CDCl}_{3}\right) \delta$ $8.21(\mathrm{~d}, J=8.5 \mathrm{~Hz}, 1 \mathrm{H}), 8.07(\mathrm{~d}, J=7.8 \mathrm{~Hz}, 1 \mathrm{H}), 7.82-7.75(\mathrm{~m}, 1 \mathrm{H}), 7.66-7.59(\mathrm{~m}$, 1H), $7.53(\mathrm{~s}, 1 \mathrm{H}), 3.04(\mathrm{q}, J=7.6,5.3 \mathrm{~Hz}, 2 \mathrm{H}), 1.28(\mathrm{~d}, J=6.3 \mathrm{~Hz}, 3 \mathrm{H}) ;{ }^{13} \mathrm{C} \mathrm{NMR}$ $\left(75 \mathrm{MHz}, \mathrm{CDCl}_{3}\right) \delta{ }^{13} \mathrm{C} \mathrm{NMR}\left(75 \mathrm{MHz}, \mathrm{CDCl}_{3}\right) \delta 202.10,182.78,145.76,132.51$, 130.02, 128.06, 127.28, 124.36, 121.70, 120.13, 119.24, 34.95, 6.89; ESI-MS m/z $[\mathrm{M}+\mathrm{Na}]^{+} 211.1$.

1.17 1-(2-Methoxyquinolin-4-yl)propan-1-one (41). To a solution of 36 (150 mg, $0.68 \mathrm{mml})$ in $10 \mathrm{~mL} \mathrm{CH} 3 \mathrm{OH}$ was added $\mathrm{CH}_{3} \mathrm{ONa}(180 \mathrm{mg}, 3.4 \mathrm{mmol})$, the mixture was stirred at refluxing temperature under nitrogen atmosphere for $4 \mathrm{~h}$. Then, the mixture was extracted with EtOAc $(3 \times 20 \mathrm{~mL})$, and the combined organic layers were then washed with brine, dried over anhydrous $\mathrm{Na}_{2} \mathrm{SO}_{4}$, and concentrated in vacuo to afford the crude product, which was purified by column chromatography with petroleum/ethyl acetate (20:1) to give 41 as yellow solid (130 mg, 88.4\%). ${ }^{1} \mathrm{H}$ NMR $\left(300 \mathrm{MHz}, \mathrm{CDCl}_{3}\right) \delta 8.17-8.08(\mathrm{~m}, 1 \mathrm{H}), 7.93-7.85(\mathrm{~m}, 1 \mathrm{H}), 7.70-7.61(\mathrm{~m}$, 1H), $7.47-7.38(\mathrm{~m}, 1 \mathrm{H}), 7.06(\mathrm{~s}, 1 \mathrm{H}), 4.10(\mathrm{~s}, 3 \mathrm{H}), 3.00(\mathrm{q}, J=7.2 \mathrm{~Hz}, 2 \mathrm{H}), 1.27(\mathrm{t}, J$ $=7.3 \mathrm{~Hz}, 3 \mathrm{H}) ;{ }^{13} \mathrm{C} \mathrm{NMR}\left(75 \mathrm{MHz}, \mathrm{CDCl}_{3}\right) \delta 204.17,161.61,147.53,146.82,129.96$, $127.73,125.26,125.11,120.94,111.68,53.65,35.72,8.01$; ESI-MS $m / z .[\mathrm{M}+\mathrm{Na}]^{+}$ 238.1.

1.18 4-Propionylquinolin-2(1H)-one (42). To a solution of $\mathbf{3 6}$ (100 mg, $0.46 \mathrm{mmol})$ in the mixture solvent of $\mathrm{H}_{2} \mathrm{O}(10 \mathrm{~mL})$ and $\mathrm{AcOH}(2 \mathrm{~mL})$ was added $\mathrm{CH}_{3} \mathrm{SO}_{2} \mathrm{Na}(92$ $\mathrm{mg}, 0.92 \mathrm{mmol})$, the mixture was stirred at $90{ }^{\circ} \mathrm{C}$ overnight. Then, the mixture was 
neutralized by saturated $\mathrm{NaHCO}_{3}$ aqueous, and extracted with EtOAc $(3 \times 20 \mathrm{~mL})$, and the combined organic layers were then washed with brine, dried over anhydrous $\mathrm{Na}_{2} \mathrm{SO}_{4}$, and concentrated in vacuo to afford the crude product, which was purified by column chromatography with petroleum/ethyl acetate (20:1) to give $\mathbf{4 2}$ as a white solid (80 mg, 87.3\%). ${ }^{1} \mathrm{H}$ NMR (300 MHz, DMSO- $\left.d_{6}\right) \delta 12.01(\mathrm{~s}, 1 \mathrm{H}), 7.67(\mathrm{~d}, J=8.2$ $\mathrm{Hz}, 1 \mathrm{H}), 7.58-7.51(\mathrm{~m}, 1 \mathrm{H}), 7.38(\mathrm{~d}, J=8.2 \mathrm{~Hz}, 1 \mathrm{H}), 7.22-7.14(\mathrm{~m}, 1 \mathrm{H}), 6.89(\mathrm{~s}$, 1H), $3.10-2.97(\mathrm{~m}, 2 \mathrm{H}), 1.16-1.02(\mathrm{~m}, 3 \mathrm{H}) ;{ }^{13} \mathrm{C}$ NMR $\left(75 \mathrm{MHz}, \mathrm{DMSO}-d_{6}\right) \delta$ 204.19, 161.18, 148.22, 139.41, 130.77, 125.67, 122.11, 120.64, 115.75, 115.16, 35.14, 7.49; ESI-MS $m / z$ [M+Na $]^{+} 224.1$.

1.19 1-(Quinolin-4-yl)propan-1-one (45). 45 was prepared as the same procedures of 21 with the commercially available $43(500 \mathrm{mg}, 3.18 \mathrm{mmol})$ as the starting material. Colorless oil (320 mg, $54.3 \%$ over two steps). ${ }^{1} \mathrm{H}$ NMR (300 MHz, $\left.\mathrm{CDCl}_{3}\right) \delta 8.89$ (d, $J=4.4 \mathrm{~Hz}, 1 \mathrm{H}), 8.21(\mathrm{dd}, J=8.6,1.4 \mathrm{~Hz}, 1 \mathrm{H}), 8.12-8.03(\mathrm{~m}, 1 \mathrm{H}), 7.70-7.63(\mathrm{~m}$, 1H), $7.56-7.48(\mathrm{~m}, 1 \mathrm{H}), 7.43(\mathrm{~d}, J=4.4 \mathrm{~Hz}, 1 \mathrm{H}), 2.95(\mathrm{q}, J=7.2 \mathrm{~Hz}, 2 \mathrm{H}), 1.19(\mathrm{t}, J$ $=7.2 \mathrm{~Hz}, 3 \mathrm{H}) ;{ }^{13} \mathrm{C} \mathrm{NMR}\left(75 \mathrm{MHz}, \mathrm{CDCl}_{3}\right) \delta 204.42,149.65,148.88,143.56,129.82$, $129.76,128.03,125.27,123.73,118.82,35.69,7.97 ;$ ESI-MS $m / z[\mathrm{M}+\mathrm{Na}]^{+} 208.1$.

\section{Biology.}

2.1 Materials. 3-(4,5-Dimethylthiazol-2-yl)-2,5-diphenyl-2-H-tetrazolium bromide (MTT), propidium iodide (PI), the Annexin V-FITC apoptosis detection kit, 5,5',6,6'-tetrachloro-1,1',3,3'-tetraethyl-imidacarbocyanine iodide (JC-1) were purchased from Nanjing KeyGen Biotech Co. Ltd. (Nanjing, China). Goat antimouse IgG/Alexa-Fluor 488 antibody was purchased from Jackson ImmunoResearch in USA. 
Primary antibodies against cdc25c, cdc2, cyclin B1, Bax, Bad, Bcl-2 and Bcl-xl were purchased from Beyotime (Jiangsu, China). The purified tubulin polymerization kit was purchased from Cytoskeleton Inc. (Denver, USA). Other reagents were purchased from Sigma-Aldrich (St. Louis, MO, USA) unless otherwise specified.

2.2 Cell Lines and Cell Culture. Human chronic myelogenous leukemia cells (K562), hepatocellular carcinoma cells (HepG2), epidermoid carcinoma of the nasopharynx cells (KB), human colon cancer cells (HCT-8), and human breast cancer cells (MDA-MB-231) were grown in RPMI 1640 medium (KeyGen Biotech Co. Ltd., Nanjing, China). Human umbilical vein endothelial cells (HUVECs) were grown in F12K medium (KeyGen Biotech Co. Ltd., Nanjing, China). The medium for all cell lines were supplemented with $10 \%$ fetal bovine serum (Life Technologies, USA), 100 $\mu \mathrm{g} / \mathrm{mL}$ streptomycin (Life Technologies, USA), and $100 \mathrm{U} / \mathrm{mL}$ penicillin (Life Technologies, USA) and maintained at $37{ }^{\circ} \mathrm{C}$ in a humidified atmosphere with $5 \%$ $\mathrm{CO}_{2}$.

2.3 MTT Assay. The overall growth of human cancer cell lines was determined using the colorimetric MTT assay. Briefly, the cell lines were incubated at $37{ }^{\circ} \mathrm{C}$ in a humidified $5 \% \mathrm{CO}_{2}$ incubator for $24 \mathrm{~h}$ in 96 -well plates prior to the experiments. K562, HepG2, KB, HCT-8, and MDA-MB-231 were seeded at a density of $5 \times 10^{3}$ cells/well. After removal of medium, $100 \mu \mathrm{L}$ of fresh medium containing the test compound at different concentrations was added to each well and incubated at $37^{\circ} \mathrm{C}$ for 24 or $72 \mathrm{~h}$. The percentage of DMSO in the medium was not exceeded $0.25 \%$. The number of living cells after $72 \mathrm{~h}$ (or $24 \mathrm{~h}$ ) of culture in the presence (or absence: 
control) of the various compounds is directly proportional to the intensity of the blue color of media, which is quantitatively measured by spectrophotometry (Biorad, Nazareth, Belgium) at a $570 \mathrm{~nm}$ wavelength. The experiment was performed in quadruplicate and repeated three times.

2.4 In Vitro Tubulin Polymerization Inhibitory Assay. The tubulin reaction mix in $100 \mu \mathrm{L}$ PEM buffer contained $2 \mathrm{mg} / \mathrm{mL}$ tubulin (Cytoskeleton), $80 \mathrm{mM}$ piperazine-N,N'-bis(2-ethanesulfonic acid) sequisodium salt PIPES (pH 6.9), $0.5 \mathrm{mM}$ EGTA, $2 \mathrm{mM} \mathrm{MgCl}$, and $15 \%$ glycerol. Then, the mixture was preincubated with compounds or vehicle DMSO on ice. PEG containing GTP was added to the final concentration of $3 \mathrm{mg} / \mathrm{mL}$ before detecting the tubulin polymerization reaction. After $30 \mathrm{~min}$, the absorbance was detected by a spectrophotometer at $340 \mathrm{~nm}$ at $37^{\circ} \mathrm{C}$ every $2 \mathrm{~min}$ for $60 \mathrm{~min}$. The area under the curve was used to determine the concentration that inhibited tubulin polymerization by $50 \%$ (IC50), which was calculated with GraphPad Prism Software version 5.02.

2.5 Competitive Inhibition Assays. The competitive binding activity of inhibitors was evaluated using a radiolabeled $[3 \mathrm{H}]$-colchicine competition scintillation proximity (SPA) assay. In brief, $0.08 \mu \mathrm{M}[3 \mathrm{H}]$-colchicine was mixed with $\mathbf{2 4 d}(1 \mu \mathrm{M}$, $5 \mu \mathrm{M})$ or CA-4 $(1 \mu \mathrm{M}, 5 \mu \mathrm{M})$ and biotinylated porcine tubulin $(0.5 \mu \mathrm{g})$ in a buffer of $100 \mu \mathrm{L}$ containing $80 \mathrm{mM}$ PIPES (pH 6.8), 1mM EGTA, $10 \%$ glycerol, $1 \mathrm{mM} \mathrm{MgCl}$, and $1 \mathrm{mM}$ GTP for $2 \mathrm{~h}$ at $37{ }^{\circ} \mathrm{C}$. Then streptavidin-labeled SPA beads $(80 \mu \mathrm{g})$ were added to each mixture. The radioactive counts were measured directly with a scintillation counter. 
2.6 Immunofluorescent Staining. K562 cells were seeded into 6-well plates and then treated with vehicle control 0.1\% DMSO, 24d (5 nM, $10 \mathrm{nM}, 20 \mathrm{nM})$. The cells were fixed with $4 \%$ paraformaldehyde and then washed with PBS for three times. After blocking for 20 min by adding $50-100 \mu \mathrm{L}$ goat serum albumin at room temperature, cells were incubated with a monoclonal antibody (anti- $\alpha$-tubulin) at $37{ }^{\circ} \mathrm{C}$ for $2 \mathrm{~h}$. Then the cells were washed three times by PBS following staining by fluorescence secondary antibody and labeling of nuclei by 4,6-diamidino-2-phenylindole (DAPI). Cells were finally visualized on a Zeiss LSM 570 laser scanning confocal microscope (Carl Zeiss, Germany).

2.7 Molecular Modeling. In our study, the X-ray structure of CA-4- $\alpha, \beta$-tubulin complex was downloaded from the Protein Data Bank (PDB code 5lyj). The protein was prepared by removal of the stathmin-like domain, subunits $\mathrm{C}$ and $\mathrm{D}$, water molecules and CA-4 using Discovery Studio modules. The docking procedure was performed by employing DOCK program in Discovery Studio 3.0 software, and the structural image was obtained using PyMOL software.

2.8 Cell Cycle Analysis. K562 cells were seeded into 6-well plates and incubated at $37{ }^{\circ} \mathrm{C}$ in a humidified $5 \% \mathrm{CO}_{2}$ incubator for $24 \mathrm{~h}$, and then treated with or without 24d at indicated concentrations for another $48 \mathrm{~h}$. The collected cells were fixed by adding $70 \%$ ethanol at $4{ }^{\circ} \mathrm{C}$ for $12 \mathrm{~h}$. Subsequently, the cells were resuspended in PBS containing $100 \mathrm{~mL}$ RNase A and $400 \mathrm{~mL}$ of propidium iodide for $30 \mathrm{~min}$. The DNA content of the cells was measured using a FACS Calibur flow cytometer (Bectone Dickinson, San Jose, CA, USA). 
2.9 Hoechst 33342 Staining. Approximately $5 \times 10^{4}$ cells per well were plated in six-well plates, and the cells were then incubated with $0,5,10$, and $20 \mathrm{nM} \mathbf{2 4 d}$ for 48 h. After incubation, cells were washed with PBS, fixed in $4 \%$ paraformaldehyde for $30 \mathrm{~min}$, and then stained with $20 \mu \mathrm{g} / \mathrm{mL}$ Hoechst 33342 for $15 \mathrm{~min}$ at room temperature in the dark. Cells were then assessed by fluorescence microscopy for morphological changes after $\mathbf{2 4 d}$ treatment.

2.10 Cell Apoptosis Analysis. After treatment with or without 24d at indicated concentrations for $48 \mathrm{~h}$, the cells were washed twice in PBS, centrifuged and resuspended in $500 \mathrm{~mL}$ AnnexinV binding buffer. The cells were then harvested, washed and stained with $5 \mathrm{~mL}$ Annexin V-APC and $5 \mathrm{~mL}$ 7-AAD in the darkness for 15 min. Apoptosis was analyzed using a FACS Calibur flow cytometer (Bectone Dickinson, San Jose, CA, USA).

2.11 Mitochondrial Membrane Potential Analysis. After treatment with vehicle control $0.1 \%$ DMSO, 24d (5 nM, $10 \mathrm{nM}$, and $20 \mathrm{nM}$ ) for $48 \mathrm{~h}$, the cells were washed in PBS and resuspended in $500 \mu \mathrm{L} \mathrm{JC}-1$ incubation buffer at $37^{\circ} \mathrm{C}$ for $15 \mathrm{~min}$. The percentage of cells with healthy or collapsed mitochondrial membrane potentials was monitored by flow cytometry analysis (Bectone-Dickinson, San Jose, CA, USA).

Measurement of Intracellular ROS Generation. Intracellular ROS production was detected by using the peroxide-sensitive fluorescent probe DCF-DA. In brief, after treatment with $0,5,10$, and $20 \mathrm{nM} \mathbf{2 4 d}$ for $48 \mathrm{~h}$, the cells were incubated with $10 \mathrm{mM}$ DCF-DA at $37{ }^{\circ} \mathrm{C}$ for 15 min. The intracellular ROS mediated oxidation of DCF-DA to the fluorescent compound 2',7'-dichlorofluorescein (DCF). Then cells were 
harvested, and the pellets were suspended in $1 \mathrm{~mL}$ PBS. Samples were analyzed at an excitation wavelength of $480 \mathrm{~nm}$ and an emission wavelength of $525 \mathrm{~nm}$ by flow cytometry on a FC500 cytometer (Beckman Coulter).

2.12 Transwell Migration and Invasion Assay. In the invasion assay, diluted Matrigel was added to the upper chamber whereas for migration assay, the chamber was not coated with Matrigel. MDB-MB231 cells $\left(1 \times 10^{5}\right.$ cells/well $)$ were cultured in the upper chambers of 24 -well transwell plates ( $8 \mu \mathrm{m}$ pore, Corning Costar), and $\mathbf{2 4 d}$ $(0,2,5$, and $10 \mathrm{nM})$ was treated on the lower surface for $48 \mathrm{~h}$. The cells on the upper surface of the membrane were removed, and the migrated or invaded cells on the bottom surface of the membranes were stained with crystal violet. The images of migrated or invaded cells at the bottom part of the chamber were captured and the number of migrated or invaded cells determined by counting cells in at least three fields from random sites.

2.13 Wound Healing Assays. K562 cells were grown in 6-well plates for $24 \mathrm{~h}$. Scratches were made in confluent monolayers using $200 \mu \mathrm{L}$ pipette tips. Then, wounds were washed twice with PBS to remove non-adherent cell debris. The media containing different concentrations $(0,5,10$, and $20 \mathrm{nM})$ of $\mathbf{2 4 d}$ were added to the petri dishes. Cells which migrated across the wound area were photographed using phase contrast microscopy at $0 \mathrm{~h}$ and $24 \mathrm{~h}$. The migration distance of cells migrated in to the wound area was measured manually.

2.14 Tube Formation Assay. EC Matrigel matrix was thawed at $4{ }^{\circ} \mathrm{C}$ overnight, and HUVECs suspended in F12K were seeded in 96-well culture plates at a cell density of 
50,000 cells/well after polymerization of the Matrigel at $37{ }^{\circ} \mathrm{C}$ for $30 \mathrm{~min}$. They were then treated with $20 \mu \mathrm{L}$ different concentrations of $\mathbf{2 4 d}$ or vehicle for $6 \mathrm{~h}$ at $37^{\circ} \mathrm{C}$. Then, the morphological changes of the cells and tubes formed were observed and photographed under inverted microscope (OLYMPUS, Japan).

2.15 Solubility Evaluation. Compounds 1 and $24 d$ were added to phosphate buffer $(50 \mathrm{mM}, \mathrm{pH} 7.4)$ at $20^{\circ} \mathrm{C}$. After shaking and centrifuging, the supernatant was taken to determine the concentration of compounds $\mathbf{1}$ and $\mathbf{2 4 d}$ in each solvent for calculation of the corresponding solubility. The samples (10 $\mu \mathrm{L}$ each) were analyzed by HPLC (Shimadzu DGU-20A3R) on Shimadzu-GL WondaSil C18-WR column. The mobile phase was acetonitrile-water $(70 / 30, \mathrm{v} / \mathrm{v})$ at a flow rate of $1.0 \mathrm{~mL} / \mathrm{min}$ with the detection wavelength at $254 \mathrm{~nm}$. This experiment was repeated in triplicates.

2.16 Acute Toxicity Determination. Five-week-old male Institute of Cancer Research (ICR) mice were purchased from Shanghai SLAC Laboratory Animals Co. Ltd. An acute toxicity study by intravenous injection was conducted according to the guidelines of the Organization for Economic Co-operation and Development. The animals were weighed and at random divided into five groups of ten animals. Then, the mice were intravenous injected with $24 d(409.6,512,640,800$, and $1000 \mathrm{mg} / \mathrm{kg}$ ) in a vehicle of $10 \% \mathrm{DMF} / 2 \%$ Tween $80 / 88 \%$ saline. The animals were observed continuously for 14 days.

2.17 In Vivo Anti-tumor Effect Evaluation. A total of $1 \times 10^{6} \mathrm{H} 22$ cells were subcutaneously inoculated into the right flank of ICR mice according to protocols of tumor transplant research. After incubation for one day, mice were weighted and at 
random divided into eight groups with eight animals per groups. The groups treated with 24d and CA-4 were administered $10,20 \mathrm{mg} / \mathrm{kg}$ in a vehicle of $10 \% \mathrm{DMF} / 2 \%$ Tween 80/88\% saline, respectively. The groups treated with $\mathbf{2 4 d - H C l}$ were administered $10,20 \mathrm{mg} / \mathrm{kg}$ in a vehicle of saline. The positive control group was treated with PTX $(8 \mathrm{mg} / \mathrm{kg})$ every 2 days by intravenous injection. The negative control group received a vehicle of $10 \% \mathrm{DMF} / 2 \%$ Tween $80 / 88 \%$ saline through intravenous injection. Treatments of $\mathbf{2 4 d}, \mathbf{2 4 d}-\mathbf{H C l}$ and CA-4 were conducted at a frequency of intravenous injection one dose per day for a total 21 consecutive days while the positive group was treated with PTX one dose per two days. Body weights and tumor volumes were measured every 2 days. After the treatments, all the mice were sacrificed and weighed. The following formula was used to determine tumor volumes: tumor volume $=\mathrm{L} \times \mathrm{W}^{2} / 2$, where $\mathrm{L}$ is the length and $\mathrm{W}$ is the width. Ratio of inhibition of tumor $(\%)=(1-$ average tumor weight of treated group/average tumor weight of control group) $\times 100 \%$. All procedures were performed following institutional approval in accordance with the NIH Guide for the Care and Use of Laboratory Animals.

2.18 Immunohistochemistry assay. Slides from mouse tissues (24d-treated group at $20 \mathrm{mg} / \mathrm{kg}$ ) were embedded in paraffin were cut to a section of $4 \mu \mathrm{m}$, deparaffinized, and treated with citrate buffer. Then, they were blocked with avidin/biotin for $20 \mathrm{~min}$. The slides were incubated with CD31 overnight at $4{ }^{\circ} \mathrm{C}$. Next, the slides were treated with secondary antibody with horseradish peroxidase goat anti-rabbit for $1-3 \mathrm{~h}$ and developed with 3, 3-diaminobenzidine. Finally, the slides were counterstained with 
hematoxylin. The mean microvessel density (MVD) was measured by calculating the CD31-positive cells in randomly selected areas in each section using image analysis software and then analyzed with OriginPro 8.0 software.

\section{SUPPORTING INFORMATION AVAILABLE}

${ }^{1} \mathrm{H}$ and ${ }^{13} \mathrm{C}$ NMR spectra for key intermediates and all target compounds, HPLC trace for compound 24d and Molecular Formula Strings are available free of charge via the internet at http://pubs.acs.org.

The statement for Molecular modeling (PDB) file: Authors will release the atomic coordinates and experimental data upon article publication.

\section{AUTHOR INFORMATION}

\section{Corresponding Authors}

*E-mail: jinyixu@china.com (J. Xu); cpuxst@163.com (S.Xu).

\section{ORCID}

Jinyi Xu: 0000-0002-1961-0402

\section{Funding}

This study was supported from the National Natural Science Foundation of China (No. 81673306, 81703348), The Open Project of State Key Laboratory of Natural Medicines, China Pharmaceutical University (No. SKLNMKF 201710), China Postdoctoral Science Foundation (No. 2017100424) for financial support, and "Double First-Class" University project CPU2018GY04, China Pharmaceutical University.

\section{Notes}

The authors declare no competing financial interest.

\section{ABBREVIATIONS USED}


CA-4, Combretastatin A-4; MEM, 2-Methoxyethoxymethyl chloride; m-CPBA, meta-chloroperoxybenzoic acid; DMAP, 4-dimethylaminopyridine; EDCI, 1-(3-(dimethylamino)propyl)-3-ethylcarbodiimide hydrochloride; HOBt, 1-hydroxybenzotriazole; DMF, dimethylformamide; DMSO, dimethyl sulfoxide; $\mathrm{Ac}_{2} \mathrm{O}$, acetic anhydride; $\mathrm{POCl}_{3}$, phosphorus oxychloride; DCM, dichloromethane; THF, tetrahydrofuran; IBX, 2-iodoxybenzoic acid; MTT, 3-(4,5-dimethyl-2-thiazolyl)-2,5-diphenyl-2-Htetrazolium bromide; PI, propidium iodide; Dess-Martin reagent, 1,1,1-Triacetoxy-1,1-dihydro-1,2-benziodoxol-3(1H)-one; ROS, reactive oxidative stress.

\section{REFERENCES}

1. Stanton R. A.; Gernert K. M.; Nettles J. H.; Aneja R. Drugs that target dynamic microtubules: A new molecular perspective. Med. Res. Rev. 2011, 31, 443-481.

2. Howard J.; Hyman A. A. Dynamics and mechanics of the microtubule plus end. Nature. 2003, 422, 753-758.

3. Jordan M. A.; Wilson L. Microtubules as a target for anticancer drugs. Nat. Rev. Cancer. 2004, 4, 253-265.

4. Islam M. N.; Iskander M. N. Microtubulin binding sites as target for developing anticancer agents. Mini-Rev. Med. Chem. 2004, 4, 1077-1104.

5. Dumontet C.; Jordan M. A. Microtubule-binding agents: a dynamic field of cancer therapeutics. Nat. Rev. Drug Discovery 2010, 9, 790-803.

6. Pettit, G. R.; Singh, S. B.; Hamel, E.; Lin, C. M.; Alberts, D. S.; Garcia-Kendal, 
D. Isolation and structure of the strong cell growth and tubulin inhibitor combretastatin A-4. Experientia. 1989, 45, 209-211.

7. Pettit, G. R.; Temple, J. C.; Narayanan, V. L.; Varma, R. A. V. I.; Simpson, M. J.; Boyd, M. R.; Bansal, N. A. M. I. T. A. Antineoplastic agents 322. Synthesis of combretastatin A-4 prodrugs. Anti-Cancer Drug Des. 1995, 10, 299-309.

8. Yakushiji, F.; Tanaka, H.; Muguruma, K.; Iwahashi, T.; Yamazaki, Y.; Hayashi, Y. Prodrug study of plinabulin using a click strategy focused on the effects of a replaceable water-solubilizing moiety. Chem. Pharm. Bull. 2012, 60, 877-881.

9. Sève P.; Dumontet C. Is class III beta-tubulin a predictive factor in patients receiving tubulin-binding agents? Lancet Oncol. 2008, 9, 168-175.

10. Stengel C.; Newman S. P.; Leese M. P.; Potter B. V.; Reed M. J.; Purohit A. Class III beta-tubulin expression and in vitro resistance to microtubule targeting agents. Br. J. Cancer. 2010, 102, 316-324.

11. Lu, Y.; Chen, J. J.; Xiao, M.; Li, W.; Miller, D. D. An overview of tubulin inhibitors that interact with the colchicine binding site. Pharm. Res. 2012, 29, 2943-2971.

12. Dong M.; Liu F.; Zhou H.; Zhai S.; Yan B. Novel natural product- and privileged scaffold-based tubulin inhibitors targeting the colchicine binding site. Molecules. 2016, $21,1375-1400$.

13. Porcù E.; Bortolozzi R.; Basso G.; Viola G. Recent advances in vascular disrupting agents in cancer therapy. Future Med. Chem. 2014, 6, 1485-1498.

14. Pérez-Pérez, M. J.; Priego, E. M.; Bueno, O.; Martins, M. S.; Canela, M. D.; 
Liekens, S. Blocking blood flow to solid tumors by destabilizing tubulin: An approach to targeting tumor growth. J. Med. Chem. 2016, 59, 8685-8711.

15. Singh P.; Anand, A.; Kumar V. Recent developments in biological activities of chalcones: a mini review. Eur. J. Med. Chem. 2014, 85, 758-777.

16. Li, W.; Sun, H.; Xu, S.; Zhu, Z.; Xu, J. Tubulin inhibitors targeting the colchicine binding site: a perspective of privileged structures. Future Med. Chem. 2017, 9, $1765-1794$.

17. Mirzaei H.; Emami S. Recent advances of cytotoxic chalconoids targeting tubulin polymerization: Synthesis and biological activity. Eur. J. Med. Chem. 2016, 121, 610-639.

18. Ducki S.; Rennison D.; Woo M.; Kendall A.; Chabert J. F.; McGown A.; Lawrence N. J. Combretastatin-like chalcones as inhibitors of microtubule polymerization. Part 1: synthesis and biological evaluation of antivascular activity. Bioorg. Med. Chem. 2009, 17, 7698-7710.

19. Lawrence N. J.; Rennison D.; McGown A. T.; Hadfield J. A. The total synthesis of an aurone isolated from Uvaria hamiltonii: aurones and flavones as anticancer agents. Bioorg. Med. Chem. Lett. 2003, 13, 3759-3763.

20. Romagnoli R.; Baraldi P. G.; Sarkar T.; Carrion M. D.; Cara C. L.; Lopez O. C.; Preti D.; Tabrizi M. A.; Tolomeo M.; Grimaudo S.; Cristina A. D.; Zonta N.; Balzarini J.; Brancale A.; Hsieh H.; Hame E. Synthesis and biological evaluation of 1-methyl-2-(3', 4', 5'-trimethoxybenzoyl)-3-aminoindoles as a new class of antimitotic agents and tubulin inhibitors. J. Med. Chem. 2008, 51, 1464-1468. 
21. Ducki S.; Forrest R.; Hadfield J. A.; Kendall, A.; Lawtence N. J.; McGowm A. T.; Rennison D. Potent antimitotic and cell growth inhibitory properties of substituted chalcones. Bioorg. Med. Chem. Lett. 1998, 8, 1051-1056.

22. Yan J.; Chen J.; Zhang S.; Hu J.; Huang L.; Li X. Synthesis, evaluation, and mechanism study of novel indole-chalcone derivatives exerting effective antitumor activity through microtubule destabilization in vitro and in vivo. J. Med. Chem. 2016, 59, 5264-5283.

23. Li W.; Yin Y.; Yao H.; Shuai W.; Sun H.; Xu S.; Liu J.; Yao H.; Zhu Z.; Xu J. Discovery of novel vinyl sulfone derivatives as anti-tumor agents with microtubule polymerization inhibitory and vascular disrupting activities. Eur. J. Med. Chem. 2018, 157, 1068-1080.

24. Álvarez R.; Aramburu L.; Puebla P.; Caballero E.; González M.; Vicente A.; Medarde M.; Peláez R. Pyridine based antitumour compounds acting at the colchicine site. Curr. Med. Chem. 2016, 23, 1100-1130.

25. Kaur, K.; Jain, M.; Reddy, R. P.; Jain, R. Quinolines and structurally related heterocycles as antimalarials. Eur. J. Med. Chem. 2010, 45, 3245-3264.

26. Solomon V. R.; Lee H. Quinoline as a privileged scaffold in cancer drug discovery. Curr. Med. Chem. 2011, 18, 1488-1508.

27. O'Boyle N. M.; Greene L. M.; Keely N. O.; Wang S.; Cotter T. S.; Zisterer M. M.; Meegan M. J. Synthesis and biochemical activities of antiproliferative amino acid and phosphate derivatives of microtubule-disrupting $\beta$-lactam combretastatins. Eur. J. Med. Chem. 2013, 62, 705-721. 
28. Pérez-Melero C.; Maya A. B. S.; Rey B. D.; Peláez R.; Caballero E.; Medarde M. A new family of quinoline and quinoxaline analogues of combretastatins. Bioorg. Med. Chem. Let. 2004, 14, 3771-3774.

29. Chaudhary V.; Venghateri J. B.; Dhaked H. P. S.; Bhoyar A. S.; Guchhait S. K.; Panda D. Novel combretastatin-2-aminoimidazole analogues as potent tubulin assembly inhibitors: exploration of unique pharmacophoric impact of bridging skeleton and aryl moiety. J. Med. Chem. 2016, 59, 3439-3451.

30. Kasibhatla S.; Baichwal V.; Cai S. X.; Roth B.; Skvortsova I.; Skvortsov S.; Lukas P.; English N. M.; Sirisoma N.; Drewe J.; Pervin.; Tseng B.; Carlson R. O.; Pleiman C. M. MPC-6827: a small-molecule inhibitor of microtubule formation that is not a substrate for multidrug resistance pumps. Cancer Res. 2007, 67, $5865-5871$.

31. Sirisoma N.; Pervin A.; Zhang H.; Jiang S.; Willardsen J. A.; Anderson M. B.; Mather Gary.; Pleiman C. M.; Kasibhatla S.; Tseng B.; Drewe J.; Cai S. Discovery of N-(4-methoxyphenyl)-N,2-dimethylquinazolin-4-amine, a potent apoptosis inducer and efficacious anticancer agent with high blood brain barrier penetration. J. Med. Chem. 2009, 52, 2341-2351.

32. Wang, X. F.; Wang, S. B.; Ohkoshi, E.; Wang, L. T.; Hamel, E.; Qian, K.; Morris-Natschke, $\quad$ S. $\quad$ L.; Lee, $\quad$ K. $\quad$ H.; $\quad$ Xie, L. N-Aryl-6-methoxy-1,2,3,4-tetrahydroquinolines: A novel class of antitumor agents targeting the colchicine site on tubulin. Eur. J. Med. Chem. 2013, 67, 196-207. 
33. Wang X.; Guan F.; Ohkoshi E.; Guo W.; Wang L.; Zhu D.; Wang S.; Wang L.; Hamel E.; Yang D.; Li L.; Qian K.; Morris-Natschke S. L.; Yuan S.; Lee K.; Xie L. Optimization of 4-(N-cycloamino)phenylquinazolines as a novel class of tubulin-polymerization inhibitors targeting the colchicine site. J. Med. Chem. 2014, 57, 1390-1402.

34. Banerjee S.; Arnst K. E.; Wang Y.; Kumar G.; Deng S.; Yang L.; Li G.; Yang J.; White S. W. Li W.; Miller D. D. Heterocyclic-Fused pyrimidines as novel tubulin polymerization inhibitors targeting the colchicine binding site: structural basis and antitumor efficacy. J. Med. Chem. 2018, 61, 1704-1718.

35. Khelifi I.; Naret T.; Renko D.; Hamze A.; Bernadat G.; Bignon J.; Lenoir C.; Dubois J.; Brion J.; Provot O.; Alami M. Design, synthesis and anticancer properties of IsoCombretaQuinolines as potent tubulin assembly inhibitors. Eur. J. Med. Chem. 2017, 127, 1025-1034.

36. Li W.; Shuai W.; Xu F.; Sun H.; Xu S.; Yao H.; Liu J.; Yao H.; Zhu Z.; Xu J. Discovery of novel 4-arylisochromenes as anticancer agents inhibiting tubulin polymerization. ACS Med. Chem. Lett. 2018, 9, 974-979.

37. Li W.; Yin, Y.; Shuai W.; Xu F.; Yao H.; Liu J.; Cheng, K.; Xu J.; Zhu Z.; Xu, S. Discovery of novel quinazolines as potential anti-tubulin agents occupying three zones of colchicine domain. Bioorg. Chem. 2019, 83, 380-390.

38. Patil R.; Patil S. A.; Beaman K. D.; Patil S. A. Indole molecules as inhibitors of tubulin polymerization: potential new anticancer agents, an update (2013-2015). Future Med. Chem. 2016, 8, 1291-1316. 
39. Patil S. A.; Patil R.; Miller D. D. Indole molecules as inhibitors of tubulin polymerization: potential new anticancer agents. Future Med. Chem. 2012, 4, $2085-2115$.

40. Argade A.; Bahekar R.; Desai J.; Thombare P.; Shah K.; Gite S.; Sunder R.; Ranvir R.; Bandyopadhyay D.; Chakrabarti G.; Joharapurkar A.; Mahapatra J.; Chatterjee A.; Patel H.; Shaikh M.; Sairam K. V. V. M.; Jain M.; Patel P. Design, synthesis and biological evaluation of $\gamma$-lactam hydroxamate based TACE inhibitors. MedChemComm 2011, 2, 966-972.

41. Dy, G. K.; Adjei, A. A. Understanding, recognizing, and managing toxicities of targeted anticancer therapies. Ca-Cancer J. Clin. 2013, 63, 249-279.

42. Gaspari R.; Prota A. E.; Bargsten K.; Cavalli A.; Steinmetz M. O. Structural basis of cis-and trans-combretastatin binding to tubulin. Chem. 2017, 2, 102-113.

43. Clarke, P. R.; Allan, L. A. Cell-cycle control in the face of damage - a matter of life or death. Trends Cell Biol. 2009, 19, 89-98.

44. Buolamwini, J. K. Cell cycle molecular targets in novel anticancer drug discovery. Curr. Pharm. Des. 2000, 6, 379-392.

45. Jordan M. A.; Wilson L. Microtubules and actin filaments: dynamic targets for cancer chemotherapy. Curr. Opin. Cell Boil. 1998, 10, 123-130.

46. Moldoveanu, T.; Follis, A. V.; Kriwacki, R. W.; Green, D. R. Many players in BCL-2 family affairs. Trends Biochem. Sci. 2014, 39, 101-111.

47. Sinha, K.; Das, J.; Pal, P. B.; Sil, P. C. Oxidative stress: the mitochondria-dependent and mitochondria-independent pathways of apoptosis. 
Arch. Toxicol. 2013, 87, 1157-1180.

48. Waris, G.; Ahsan, H. Reactive oxygen species: role in the development of cancer and various chronic condition. J. Carcinog. 2006, 5, 14.

49. Yamaguchi, H.; Wyckoff, J.; Condeelis J.; Cell migration in tumors. Curr. Opin. Cell Biol. 2005, 17, 559-564.

50. Friedl, P.; Wolf, K. Tumour-cell invasion and migration: diversity and escape mechanisms. Nat. Rev. Cancer. 2003, 3, 362-374.

51. Schwartz, E. L. Antivascular actions of microtubule-binding drugs. Clin. Cancer Res. 2009, 15, 2594-2601.

52. Lamalice L.; Boeuf F. L.; Huot J. Endothelial cell migration during angiogenesis. Circ. Res. 2007, 100, 782-794.

53. Lamaa, D.; Lin, H.; Zig, L.; Bauvais, C.; Bollot, G.; Bignon, J.; Levaique, H.; Pamlard, O.; Dubois, J.; Ouaissi, M.; Souce, M.; Kasselouri, A.; Saller, F.; Borgel, D.; Jayat-Vignoles C.; Al-Mouhammad, H.; Feuillard, J.; Benihoud, K.; Alami, M.; Hamze, A. Design and synthesis of tubulin and histone deacetylase inhibitor based on iso-combretastatin A- 4. J. Med. Chem. 2018, 61, 6574-6591.

54. Gross, G.; Tardio, J.; Kuhlmann, O. Solubility and stability of dalcetrapib in vehicles and biological media. Int. J. Pharm. 2012, 437, 103-109.

55. Chen, J.; Wang, Z.; Li, C. M.; Lu, Y.; Vaddady, P. K.; B. Meibohm, J.T. Dalton, D.D. Miller, W. Li, Discovery of novel 2-aryl-4-benzoyl-imidazoles targeting the colchicines binding site in tubulin as potential anticancer agents, J. Med. Chem. 2010, 53, 7414-7427. 
56. Bonacorso H. G.; Nogara P. A.; Silva F.; Rosa W. C.; Wiethan C. W.; Zanatta N.; Martins M. A. P.; Rocha J. B. T. Convergent synthesis and cytotoxicity of novel trifluoromethyl-substituted (1H-pyrazol-1-yl)(quinolin-4-yl) methanones. $J$. Fluorine. Chem. 2016, 190, 31-40. 


\section{Table of Contents Graphic}

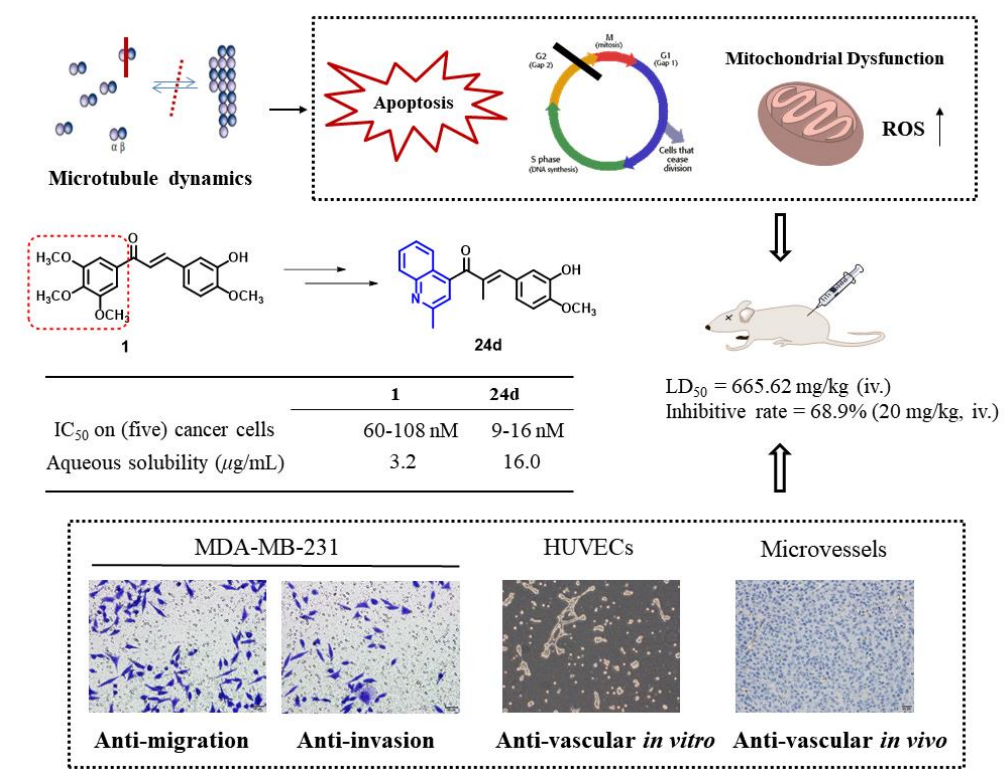

